\title{
Micropaleontology of the lower Mesoproterozoic Roper Group, Australia, and implications for early eukaryotic evolution
}

\author{
Emmanuelle J. Javaux, ${ }^{1}$ and Andrew H. Knoll ${ }^{2}$ \\ ${ }^{1}$ Department of Geology, UR Geology, University of Liège, 14 allée du 6 Août B18, Quartier Agora, Liège 4000, Belgium 〈ej.javaux@ @lg.ac.be〉 \\ ${ }^{2}$ Department of Organismic and Evolutionary Biology, Harvard University, Cambridge, Massachusetts 02138, USA 〈aknoll@oeb.harvard.edu〉
}

\begin{abstract}
Well-preserved microfossils occur in abundance through more than $1000 \mathrm{~m}$ of lower Mesoproterozoic siliciclastic rocks composing the Roper Group, Northern Territory, Australia. The Roper assemblage includes 34 taxa, five interpreted unambiguously as eukaryotes, nine as possible eukaryotes (including Blastanosphaira kokkoda new genus and new species, a budding spheromorph with thin chagrinate walls), eight as possible or probable cyanobacteria, and 12 incertae sedis. Taxonomic richness is highest in inshore facies, and populations interpreted as unambiguous or probable eukaryotes occur most abundantly in coastal and proximal shelf shales. Phylogenetic placement within the Eukarya is difficult, and molecular clock estimates suggest that preserved microfossils may belong, in part or in toto, to stem group eukaryotes (forms that diverged before the last common ancestor of extant eukaryotes, or LECA) or stem lineages within major clades of the eukaryotic crown group (after LECA). Despite this, Roper fossils provide direct or inferential evidence for many basic features of eukaryotic biology, including a dynamic cytoskeleton and membrane system that enabled cells to change shape, life cycles that include resting cysts coated by decay-resistant biopolymers, reproduction by budding and binary division, osmotrophy, and simple multicellularity. The diversity, environmental range, and ecological importance of eukaryotes, however, were lower than in later Neoproterozoic and Phanerozoic ecosystems.
\end{abstract}

\section{Introduction}

In classifying the past 541 million years as the Phanerozoic Eon, stratigraphers give formal recognition to the animal fossils commonly found in rocks of this age. In terms of evolution, the age of animals must form the latter part of a phylogenetically broader and historically deeper age of eukaryotes, but when protists emerged as major participants in marine ecosystems remains uncertain. Molecular clocks, calibrated largely by Phanerozoic fossils, nearly all suggest that crown group eukaryotes emerged during the Proterozoic Eon. The error bars are large, but even so, the oldest (ca. $2000 \mathrm{Ma}$ ) and youngest (800 Ma or a bit earlier) molecular estimates for the divergence of crown group eukaryotes do not overlap (e.g., Douzery et al., 2004; Hedges et al., 2004; Yoon et al., 2004; Berney and Pawlowski, 2006; Chernikova et al., 2011; Parfrey et al., 2011; Eme et al., 2014). Neither early nor late crown group emergence precludes the possibility of a substantial earlier record of stem group eukaryotes (Javaux et al., 2010; Javaux, 2011; Knoll, 2014; Sugitani et al., 2015; Butterfield, 2015).

Diverse eukaryotic microfossils occur in rocks $800 \mathrm{Ma}$ and younger (Porter et al., 2003; Butterfield, 2004; Butterfield, 2005a, 2005b; Knoll et al., 2006; Cohen and Knoll, 2012), and these include at least a few populations assigned with confidence to extant eukaryotic clades (e.g., Butterfield et al., 1994; Porter et al., 2003). Accepting the 1100-Ma fossil Bangiomorpha pubescens as a red alga (Butterfield, 2000), possibly a stem group rhodophyte (Yang et al., 2016), further requires that crown group eukaryotes evolved earlier than this. Older microfossils potentially push the eukaryotic crown group still deeper into the past (Moczydłowska et al., 2011; Butterfield, 2015), but only if these fossils can be confidently interpreted not only as eukaryotes but also as crown versus stem group taxa-a potentially challenging distinction in ancient rocks (Knoll, 2014).

Improved understanding of the timing and context of early eukaryotic divergence begins with careful systematic analysis of well-preserved fossil populations drawn from basins characterized by good age and environmental control. One such basin is recorded by the Mesoproterozoic Roper Group, Northern Territory, Australia. Abundant microfossils were discovered in coastal marine mudstones of the McMinn Formation, near the top of the group (Peat et al., 1978). Our investigations reveal that fossils are abundant and exceptionally well preserved throughout the Roper succession, enabling us to document the paleoenvironmental as well as stratigraphic distribution of microfossil assemblages (Javaux et al., 2001).

\section{Geologic setting}

The Roper Group is a ramp-like sedimentary succession developed in association with regional rifting following an episode of late Paleoproterozoic tectonism known locally as the Isan Orogeny (Betts and Gilles, 2006; de Vries et al., 2008). Although limited Roper outcrop is dominated by erosionally resistant sandstone units, an extensive and lithologically 
heterogeneous record of Roper deposition is available in drill core obtained during the 1970 s and 1980s. The $>1800 \mathrm{~m}$ Roper succession consists almost entirely of siliciclastic rocks divided by Abbott and Sweet (2000) into half a dozen third-order sedimentary sequences. Environments recorded in each sequence range from basinal black shales deposited below storm wave base during maximum flooding to paralic and even fluviatile sandstones, as well as oolitic ironstones found as a marginal-marine facies in highstand systems tracts. Depositional age is constrained by a U-Pb zircon age of $1492 \pm 4$ Ma for a tuff in the Mainoru Formation, low in the Roper succession (Jackson et al., 1999), Re-Os shale dates of $1417 \pm 29 \mathrm{Ma}$ and $1361 \pm 21 \mathrm{Ma}$ for the Velkerri Formation in the upper part of the succession (Kendall et al., 2009), and a less reliable, but broadly consistent $\mathrm{Rb}$-Sr illite date of $1429 \pm 31$ Ma for shale within the McMinn Formation, near the top of the group (Kralick, 1982). Thus, Roper deposition took place about 1500-1400 Ma (Figure 1).

Surface waters in the Roper seaway were oxic, as determined by iron-speciation chemistry (Shen et al., 2003), but several lines of evidence indicate that within the Roper basin the oxygen minimum zone was commonly anoxic and ferruginous, and at times euxinic (Shen et al., 2003; Planavsky et al., 2011). Consistent with this, $\mathrm{S}$ isotopic data document an active microbial sulfur cycle (Shen et al., 2003; Johnston et al., 2008), with facies-specific differences in expressed fractionation suggesting that bacterial sulfate reduction occurred in the water column in basinal environments, but was confined to sediments in coastal settings (Shen et al., 2003). Mo abundance and isotope values for Roper samples point more broadly to early Mesoproterozoic oceans with widespread subsurface anoxia, including sulfidic water masses more extensive than today (Arnold et al., 2004; Kendall et al., 2009), with some exceptions locally (Sperling et al., 2014).

\section{Materials and methods}

Carbonaceous shales occur throughout the Roper succession in environmental settings that range from basinal to lagoonal (Abbott and Sweet, 2000; Javaux et al., 2001). A majority of these shales contain microfossils preserved as organic compressions, and in a subset of these, distributed throughout the succession, preservation is excellent. The fossils described here come from the following cores: Amoco (A) 82-3 and Golden Grove (GG) 1, reposited at the Northern Territory Geological Survey in Darwin, and Urapunga (U) cores 4, 5, and 6, reposited at the Australian Geological Survey Organization, Canberra. Collectively, these cores represent most of the Roper Group, save for the upper McMinn and Chambers River formations at the top of the succession.

All microfossils come from residues of static acid maceration and have been examined with transmitted light microscopy. For some taxa, detailed morphological observations with SEM, wall ultrastructure with TEM, and wall microchemistry are described elsewhere (Javaux et al., 2003, 2004; Marshall et al., 2005). Systematic description is focused on the genus and species levels, with taxa ordered alphabetically, and the International Code of Nomenclature for Algae, Fungi, and Plants is followed. Sample number includes core number and depth (e.g., U6 $230.8 \mathrm{~m}$ is sample from core Urapunga 6 at $230.8 \mathrm{~m}$ depth).
Repositories and institutional abbreviations.-All illustrated specimens are reposited in the Paleobotanical Collections of Harvard University (HU numbers).

\section{Systematic paleontology}

Classification of Roper microfossils presents challenges at either end of the Linnean hierarchy, in both cases reflecting the limited availability of systematically useful characters and character states. At the fine scale, the challenge is to recognize discrete populations and classify them in light of previously diagnosed taxa. Populations can be demarcated in terms of general form (e.g., spheroidal versus cylindrical), size frequency distribution, surface ornamentation when present, and wall thickness and textures (when obvious ornamentation is absent).

Preliminary research shows that morphologically simple Mesoproterozoic microfossils can also preserve distinct wall ultrastructures (Javaux et al., 2004), but extensive TEM imaging would be prohibitive, and existing diagnoses do not take ultrastructural characters into account. Because of character limitations and the ways that observed traits have been used in classification, it can be easier to recognize populations as distinct than it is to assign them to formal taxa, especially for the abundant but simple spheroidal vesicles known as leiosphaerids. We recognize 34 distinct entities within the Roper assemblage.

The other systematic challenge is to relate Roper populations to higher taxa, which can be problematic even at the level of domain. For this reason, we find it useful to provide qualitative confidence estimates for phylogenetic interpretation-with what degree of certainty we recognize a given population as eukaryotic or bacterial. We show that five morphospecies can be classified with confidence as eukaryotes, including three distinct populations of ornamented spheromorphic acritarchs (Dictyosphaera delicata, Satka favosa, and Valeria lophostriata), one acanthomorphic acritarch (Tappania plana), and one population of large striated tubes (Lineaforma elongata). Nine additional taxa are considered possible eukaryotes (six smooth-walled spheromorphs: Leiosphaeridia crassa, L. jacutica, L. minutissima, L. tenuissima, Leiosphaeridia sp., and L. ternata; one spheromorph population with a granular wall texture (L. atava), and two populations of budding spheromorphs (cf., Gemuloides doncookii and Blastanosphaira kokkoda). Eight taxa of filaments (Palaeolyngbya catenata, five species of Siphonophycus, Trachytrichoides sp.) and vesicles with rounded bulges inferred to be imprints of internal cells (Squamosphaera colonialica), are interpreted as probable cyanobacteria, whereas 12 distinctive populations can be classified only as incertae sedis; this group includes five types of spheromorphs (Unnamed forms $\mathrm{B}$ to E), six colonial forms (Chlorogloeaopsis contexta, cf. Coneosphaera arctica, Eomicrocystis magilca, Synsphaeridium spp., Symplassosphaeridium spp., and a large compartmentalized multicellular form-unnamed form A), and two filamentous taxa (Tortunema sp. and unnamed form F). Some of the Roper colonial and filamentous microfossils are interpreted as probable cyanobacteria because of both their occurrence in shallow-water photic zone and their morphology. 

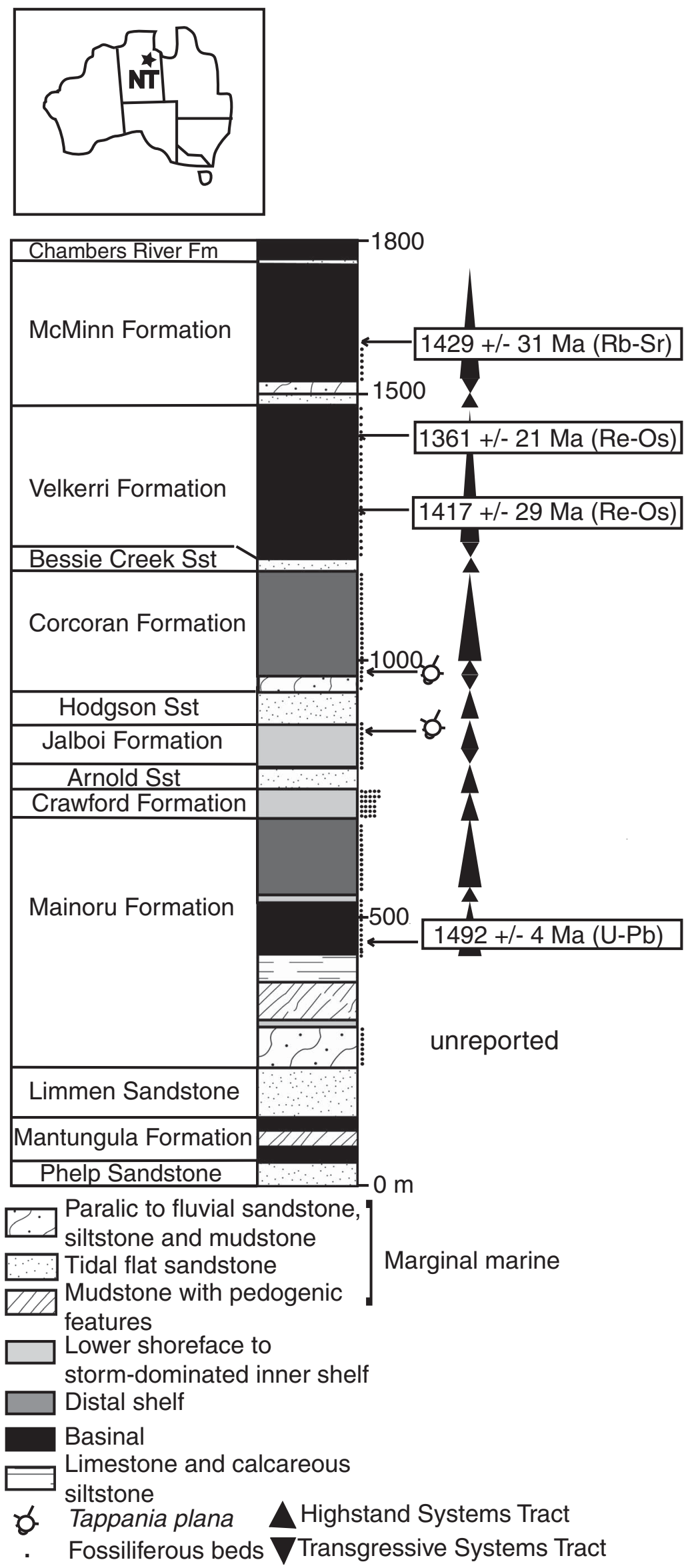

Figure 1. The Roper Group, showing location, facies distribution and stratigraphic column (modified from Javaux et al., 2001). 


\section{Genus Blastanosphaira new genus}

Type species.—Blastanosphaira kokkoda, by monotypy

Diagnosis.—As for type species.

Etymology.-From the greek $\beta \lambda \alpha \sigma \tau \alpha \omega \omega$, to bud or to germinate,

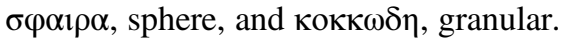

\section{Blastanosphaira kokkoda new species}

Figure 2.1-2.11

Holotype.-Specimen Figure 2.1, palynological slide U5 $569.1 \mathrm{~m}$, England finder coordinates R/S42, from the Wood Duck Member of the Mainoru Formation, Roper Group.

Diagnosis. - Spheromorph, a few up to $\sim 100 \mu \mathrm{m}$ in diameter, with very thin chagrinate wall, small sinuous folds, and one lanceolate fold predominantly near the margins of compressed vesicles. Division by budding, with one or several large spherical scars left by detaching buds; serial budding without cells detaching common, leading to a colonial habit. Commonly, taphonomic alteration results in the thin wall peeling off the vesicle from an equally tenuous internal layer.

Occurrence.-Mesoproterozoic, Wood Duck Member of the Mainoru Formation, Roper Group, Australia.

Description.-Spheromorph with very thin chagrinate wall and small sinuous folds, and one lanceolate fold predominantly near the margins of compressed vesicles. Size 3-93 $\mu \mathrm{m}$ in minimum diameter (mean: $28.7 \mu \mathrm{m}, \sigma=16.8 \mu \mathrm{m}, \mathrm{N}=149$ ). Two specimens oval shaped (52-104 $\mu \mathrm{m}$ long and 32-64 $\mu \mathrm{m}$ wide), and one specimen $(27 \mu \mathrm{m}$ in diameter) bears an elongate expansion ( $40 \mu \mathrm{m}$ long $\mathrm{x} 8 \mu \mathrm{m}$ wide) (Fig. 2.3). Division by budding, with cells staying attached and forming irregular colonies, cells rarely isolated, often attached to one to four other cells, commonly with large spherical scars left by detaching buds or adjacent cells. Range of diameter and morphology may vary greatly, from spherical to oval to filamentous. Commonly, taphonomic alteration results in the thin wall peeling off the vesicle from an equally tenuous internal layer.

Materials.-149 specimens measured, as clustered populations in basinal facies (samples U5 $581.9 \mathrm{~m}$ and $569.1 \mathrm{~m}$ in the Wood Duck Member of the Mainoru Formation).

Remarks.-The Roper population forms an essentially monospecific assemblage in euxinic basinal shales, and is rare in other facies. It differs from Gemmuloides by the thin chagrinated wall, circular scars, and multiple attached buds forming colonies. It also differs from Eosaccharomyces ramosus Hermann, another budding spheromorph forming colonies, by the chagrinate ornamentation of the vesicle wall, and taphonomic features such as circular scars (Fig. 2.4) and one large lanceolate fold at periphery and very thin folds more centrally distributed (Fig. 2.1, 2.10). The attachment to a biofilm reported and illustrated by Hermann (1990, pl. 14) and Hermann and Podkovyrov (2012) is not observed for the Roper population, although it is not mentioned as a diagnostic character (Jankauskas et al., 1989). Growth of oval cells oriented in the direction of the "branches" of the colony do occur in the Lakhanda material, as underscored by Knoll et al. (2006), but this is not always the case (see Hermann 1990, pl. 14, figs. 5, 7), and is not reported as a diagnostic criterion in Jankauskas et al. (1989). The chagrinate spheromorphs commonly show evidence of budding (Fig. 2.2-2.8), forming spheres (Fig. 2.6-2.8) or elongate extensions (Fig. 2.3), with up to seven specimens attached. Some specimens bear a distinct circular hole rimmed by a fold in the wall (with a diameter up to more than $60 \%$ of the vesicle diameter) (Fig. 2.4). Because budding specimens may bear this hole (Fig. 2.7), it cannot be interpreted as a pylome (excystment structure), but rather as a scar left when connected individuals detached. Commonly, the thin wall has partially peeled off, exposing the lighter inner side of the vesicle wall (Fig. 2.6). Cells can be isolated, or more commonly attached to 1 to 4 other cells (Fig 2.7). Blastanosphaira kokkoda differs also from other spheromorphs with chagrinate walls, such as $L$. obsuleta and $L$. atava, by its prominent budding habit and consequent colonial association, very thin wall, and circular scars.

The chagrinate appearance seems to be an ornamentation rather than taphonomic alteration, suggesting eukaryotic affinity. SEM shows a granular wall and occasional taphonomic holes (Fig. 2.11). Budding is also consistent with eukaryotic affinities, resembling yeast behavior, but detailed ultrastructural and microchemical analyses will be required to confirm the affinity of this population. Due to its budding without cells detaching and forming colonies, E. ramosus has been interpreted as a possible fungus (yeast-like) by Hermann and Podkovyrov (2012) or as social amoebae, although these are difficult to preserve as compressions (Porter, 2006), except in stages of their life cycle when they can produce cellulose walls. Interestingly, cells of the modern yeast Saccharomyces may bear several circular scars, and when budding rapidly, form pseudomycelia. However, budding as a form of asexual reproduction also occurs in some bacteria (cyanobacteria, prosthecate proteobacteria; Angert, 2005), in addition to some protists, fungi (yeast), and animals. The chagrinate ornamentation of the wall combined with large size suggest the Roper fossils are probable eukaryotes, and their common budding and pseudocolonial habit shows they represent metabolically active, reproducing vegetative cells. Their restricted distribution in deeper anoxic facies may suggest an anaerobic metabolism (see Muller et al., 2012 for a review of modern anaerobic eukaryotes)

Figure 2. Photographs of Roper organic-walled microfossils: (1-11) Blastanosphaira kokkoda n. gen. n. sp.; (2) specimen starting budding; (3) specimen showing an elongate expansion; (4) specimen showing circular opening; (6) the bottom specimen's wall is peeling off the vesicle; (8) thick folds between attached specimens; (5-8) specimens showing multiple budding; (11) SEM picture showing details of granular wall. (12-13) Chlorogloeaopsis contexta. (14) Coneosphaera artica. (15) Dictyosphaera delicata. (16-18) Eomicrocystis magilca: (17) detail of (16) showing oval cells and absence of external envelope. Scale bar in (1) is: (1, 2, 8, 9, 10) $13 \mu \mathrm{m}$; (3, 14, 16, 18) $20 \mu \mathrm{m} ;(\mathbf{4}, \mathbf{1 3}, \mathbf{1 7}) 10 \mu \mathrm{m} ;(\mathbf{5}) 80 \mu \mathrm{m} ;(\mathbf{6}, \mathbf{7}) 15 \mu \mathrm{m} ;(\mathbf{1 1}) 500 \mathrm{~nm}$; (12) 50 $\mu \mathrm{m}$. Slides and England coordinates are (1) U5 569.1 m .2 Q42, (2, 3) U5 569.1 m .2 Q40/2, (4) U5 569.1 m .2 R43, (5) U5 569.1 m .2 R/S42, (6) U5 569.1 m .2 R43, (7-10) U5 536.6 m .2 P33, (12, 13) U6 240.2 m .2 S16, (14) A82/3 311.3 m O5/2, (15) GG1 48.75 m .2 J43/4, (16) U5 125.1 m .2 N33/2, (18) U6 230.8 m H16. 

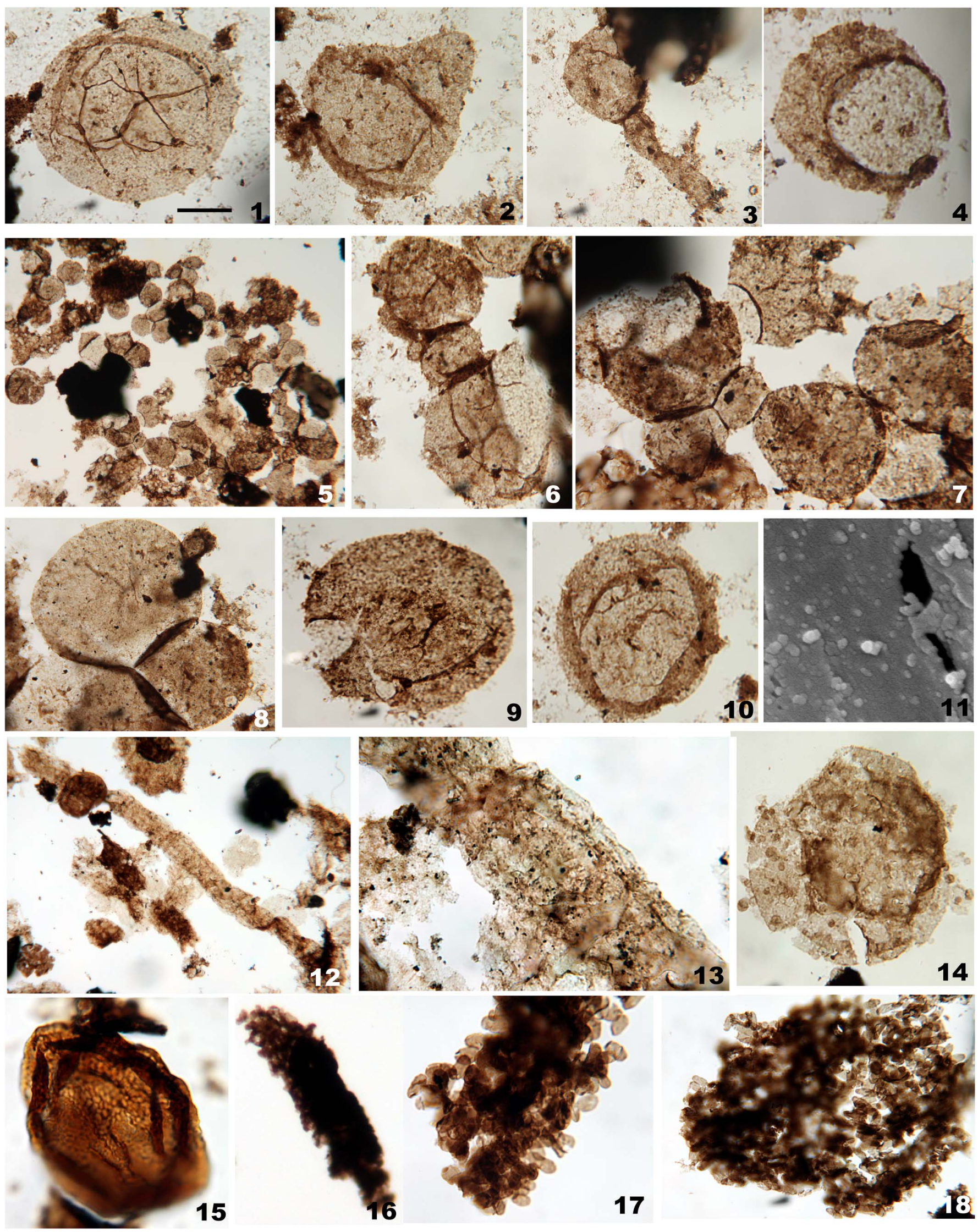
or facultatively aerobic metabolism at low oxygen tensions. Alternatively, they could have been planktonic, but in this case, their limitation to deeper anoxic facies is difficult to explain.

Genus Chlorogloeaopsis Maithy, 1975, emend. Hofmann and Jackson, 1994

Type species.—Chlorogloeaopsis zairensis Maithy, 1975, from the Bushimay (now Mbuyi-Mayi) Supergroup, RDC, Meso-Neoproterozoic.

Other species.-Chlorogloeaopsis kanshiensis (Maithy, 1975), n. comb. Hofmann and Jackson, 1994; Chlorogloeaopsis contexta (Hermann, 1976) n. comb. Hofmann and Jackson, 1994.

Chlorogloeaopsis contexta (Hermann in Timofeev, Hermann, and Mikhailova, 1976), emend. Hofmann and Jackson, 1994

Figure 2.12-2.13

1976 Polysphaeroides contextus Hermann in Timofeev, Hermann, and Mikhailova, p. 42, pl. 14, fig. 3

1989 Polysphaeroides contextus; Jankauskas et al., p. 119, pl. 27, figs. 10a, b

1990 Polysphaeroides contextus; Hermann, p. 26, pl. 8, fig. 8

1994 Chlorogloeaopsis contexta; (Hermann in Timofeev et al., 1976), emend. Hofmann and Jackson, p. 19, figs. 12.13-12.15

Holotype.-Polysphaeroides contextus Hermann, 1976 in Timofeev, Hermann, and Mikhailova, p. 42-43, pl. 14, fig. 3; from the late Riphean (Tonian) Miroedikha Formation of the Turukhan Uplift, Siberia.

Occurrence.-Mesoproterozoic and Neoproterozoic successions worldwide, such as the Mbuyi-Mayi Supergroup, RDC; the Miroedikha Formation of the Turukhan Uplift, Siberia; the Roper Group, Australia; the Bylot Supergroup, Canada.

Description.-One cylindrical colony without envelope, composed of several indistinctly defined rows of cells 3-5 $\mu \mathrm{m}$ wide; colony $400 \mu \mathrm{m}$ long and $25 \mu \mathrm{m}$ wide.

Materials.-One specimen from sample U6 $240.2 \mathrm{~m}$, Mainoru Formation.

Remarks.-The spelling of the genus was corrected by Hofmann and Jackson (1994, p. 18-19) and simultaneously (both in July 1994) by Butterfield et al. (1994, p. 72). Hofmann and Jackson (1994) recognized three species of Chlorogloeaopsis: C. contexta (Hermann, 1976) n. comb. Hofmann and Jackson, 1994, has indistinct rows of cells and cell diameter ranging from 1 to $5 \mu \mathrm{m}$; C. zairensis Maithy, 1975 with cells 8 to $10 \mu \mathrm{m}$ in diameter, two to four in a row, while C. kanshiensis has cells $10-15 \mu \mathrm{m}$ in diameter, two or three distinct rows of cells. The Roper population differs from C. kanshiensis, defined by two or three rows of cells, and from Polysphaeroides spp., which are loose aggregates of spheroidal dispersed cells or pairs, tetrads, octads, and spheroidal colonies of up to 10-20 cells in a sheath.

\section{Genus Coneosphaera Luo, 1991}

Type species.-Coneosphaera inaequalalis Luo, 1991, from the Changlongshan Formation, Neoproterozoic, China.

Other species.-Coneosphaera artica Hofmann and Jackson, 1994; Coneosphaera sp. Hofmann and Jackson, 1994.

Coneosphaera sp.

Figure 2.14

Description. - 50-51 $\mu \mathrm{m}$ thin-walled light brown spheromorphs loosely associated with many smaller $2-4 \mu \mathrm{m}$ vesicles on the wall surface and close to their periphery. Three specimens observed.

Materials.-Three specimens from sample U6 $226.95 \mathrm{~m}$, Mainoru Formation.

Remarks.-Our specimens differ from $C$. artica, which shows larger diameters of both large and small vesicles $(79-130 \mu \mathrm{m}$ and $8-11 \mu \mathrm{m}$, respectively) and a higher number of the loosely attached or closely associated small vesicles. It also differs from $C$. sp. in the Bylot Group (Hofmann and Jackson, 1994), which has a few vesicles firmly attached to a larger central one and resembles a specimen illustrated by Hermann (1990, p. 20, pl. 5.11) in the Miroedikha Formation, Siberia. It differs from $C$. inaequalalis, which is characterized by a large cell three or four times bigger than the attached smaller cells, and one cell much smaller than the others (Luo, 1991, p. 193).

Genus Dictyosphaera Xing and Liu, 1973

Type species.-Dictyosphaera macroreticulata Xing and Liu, 1973, from the Chuanlingguo Formation, Yenliao region; Chih County of Hopei, northern China, Mesoproterozoic.

Dictyosphaera macroreticulata Xing and Liu, 1973 Figure 2.15

1973 Dictyosphaera macroreticulata Xing and Liu, p. 22, 58, pl. 1, 16-17.

1982 Dictyosphaera delicata; Hu and Fu, p. 108, pl. 2, figs. 3-6. 2001 Dictyosphaera sp.; Javaux et al., fig 1e.

2003 Dictyosphaera delicata; Kaufman and Xiao, fig. 1.

2005 Dictyosphaera delicata; Yin et al., p. 52, fig. 2.1, 2.2, 2.4, 2.5, 2.7, 2.9, 2.10.

2007 Dictyosphaera delicata; Yin and Yuan, p. 351, fig. 1.1.

2009 Dictyosphaera delicata; Schiffbauer and Xiao, fig. 3f.

?2011 "ellipsoidal vesicle with a micro-reticulate wall" Strother et al., fig. 1i, j.

2015 Dictyosphaera macroreticulata; Agic et al., p. 32, figs. 2-4.

Lectotype.-Specimen originally described as Dictyosphaera sinica Xing and Liu, 1973, from the Chuanlingguo Formation, Yenliao region, Chih County of Hopei, northern China, Mesoproterozoic, and junior synonym of D. macroreticulata Xing and Liu (1973, pl. I:18) (Agic et al., 2015). 

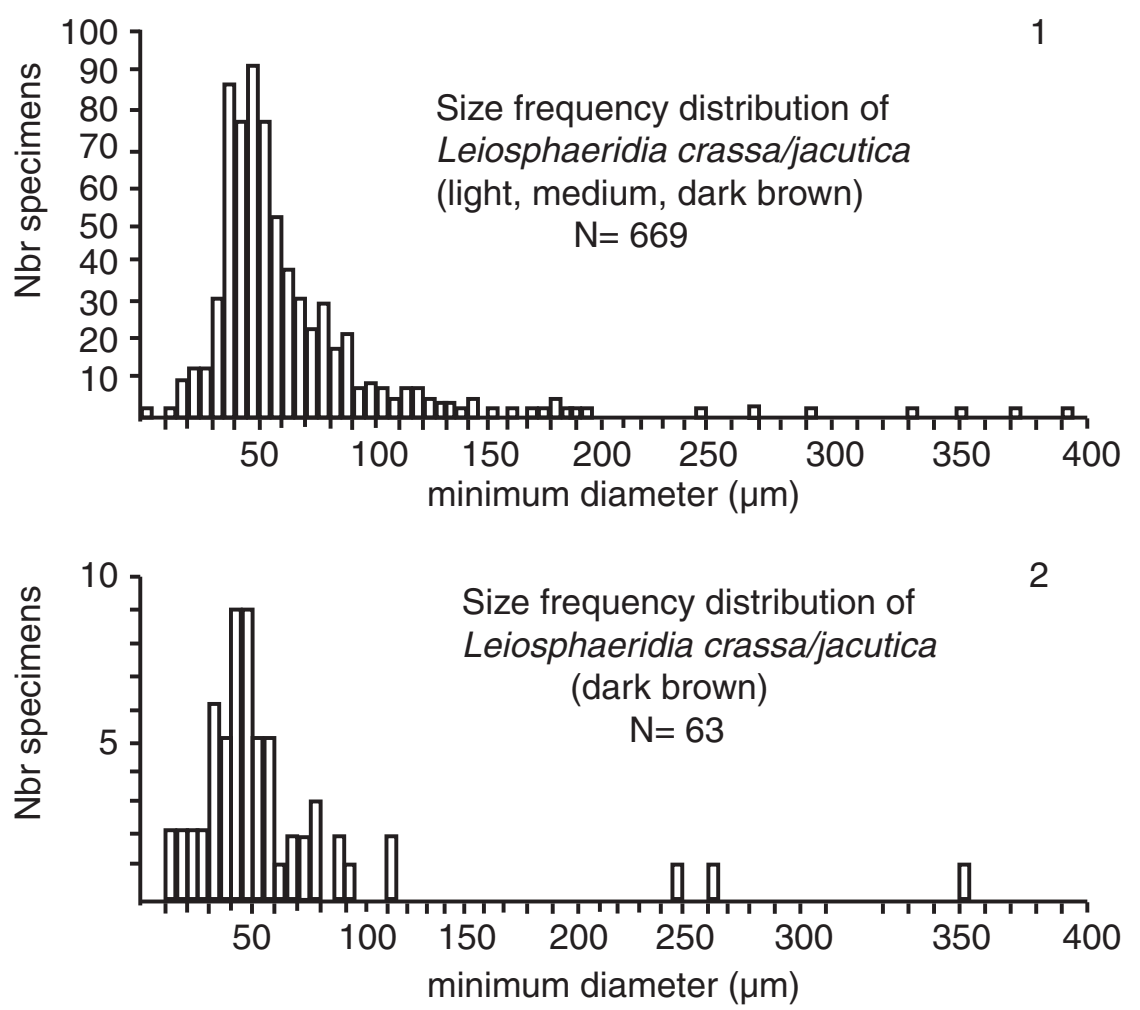
Size frequency distribution of 5 Leiosphaeridia minutissima/tenuissima (light and medium brown)

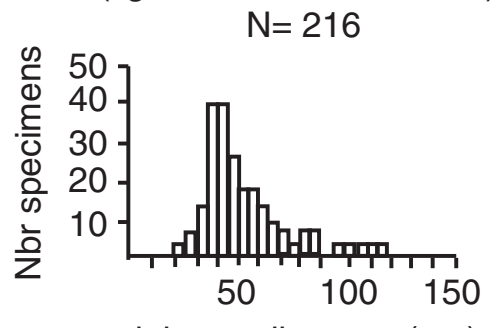

minimum diameter $(\mu \mathrm{m})$

Size frequency distribution of 6 Leiosphaeridia minutissima/tenuissima (light brown)
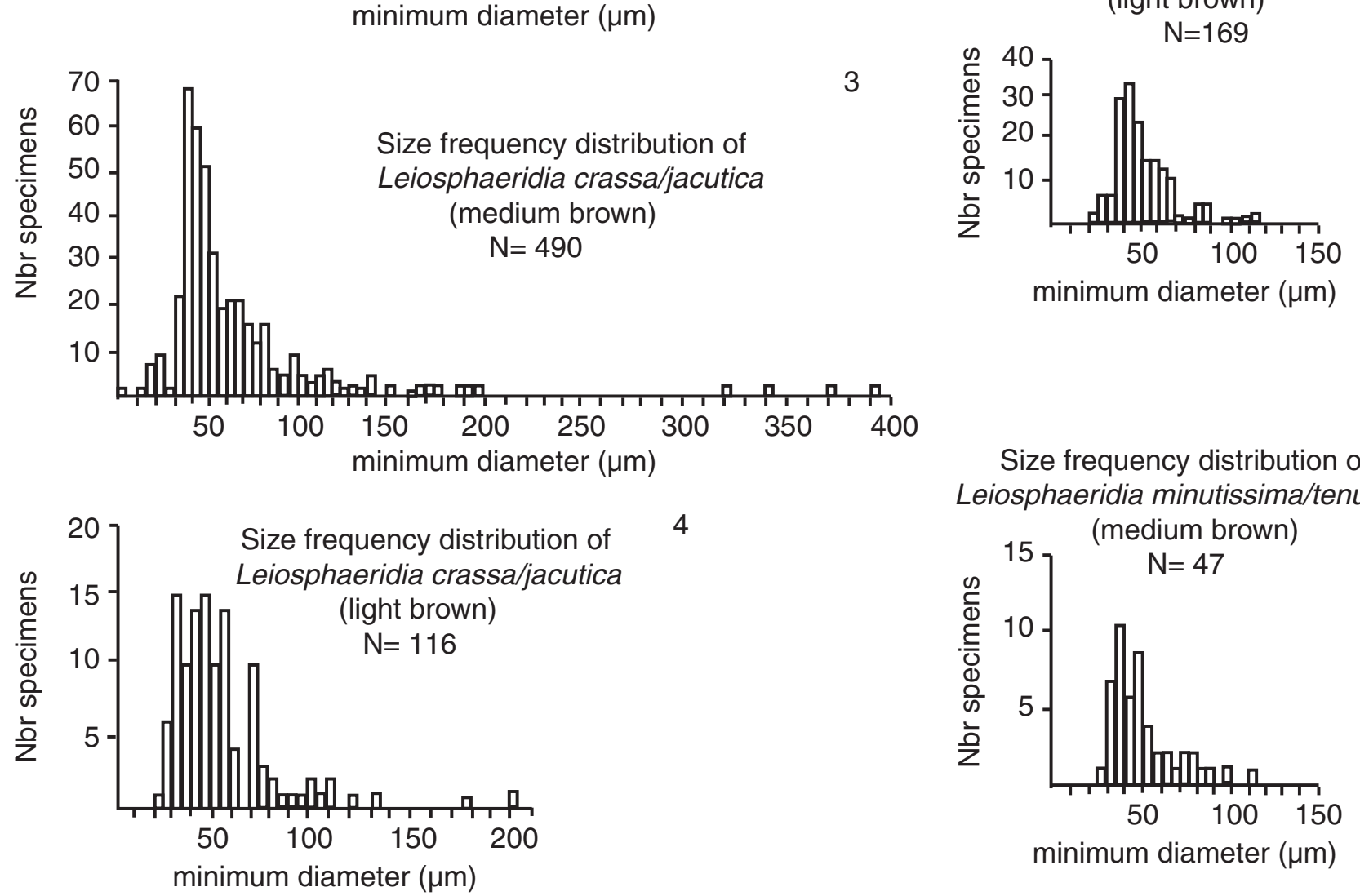

Size frequency distribution of 7 Leiosphaeridia minutissima/tenuissima

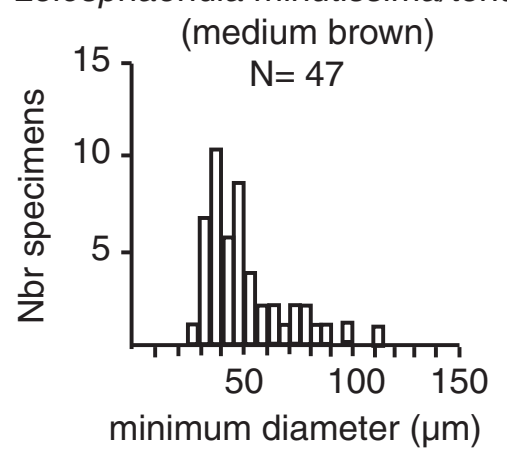

Figure 3. Size frequency distribution of leiospheres: (1) Size frequency distribution of all Leiosphaeridia crassaljacutica (dark-, medium-, and light-brown walls); (2) Size frequency distribution of dark-brown Leiosphaeridia crassaljacutica; (3) Size frequency distribution of medium-brown Leiosphaeridia crassal jacutica; (4) Size frequency distribution of light-brown Leiosphaeridia crassaljacutica; (5) Size frequency distribution of all Leiosphaeridia minutissimal tenuissima (medium- and light-brown walls); (6) Size frequency distribution of light-brown Leiosphaeridia minutissima/tenuissima; (7) Size frequency distribution of medium-brown Leiosphaeridia minutissimaltenuissima. 
Occurrence.-Paleoproterozoic and Mesoproterozoic of China (Ruyang and Gaoshanhe Groups) (Xing and Liu, 1973), Australia (Roper Group) (Javaux et al., 2001), Belt Supergroup (Adam, 2014).

Description.-Only three specimens observed in the Roper population, one specimen measured: $50 \mu \mathrm{m}$ in diameter with polygonal plates less than $2 \mu \mathrm{m}$ wide. No excystment structure observed.

Materials.-Three specimens in basinal mudstones of the Velkerri Formation (sample GG1 $48.75 \mathrm{~m}$ ).

Remarks.-Agic et al. (2015) revised the taxonomy of the genus Dictyosphaera and synonymized all the species previously described (D. delicata, D. sinica, D. gyrorugosa, D. incrassata) to the senior species $D$. macroreticulata, described as 10 to $300 \mu \mathrm{m}$ vesicles ornamented by a reticulate polygonal pattern consisting of interlocking 1-6 $\mu \mathrm{m}$ polygonal plates. Excystment by pylome or medial split. Because the holotype was not available for re-examination, they selected a lectotype from the same material as the holotype. In their original diagnosis, $\mathrm{Hu}$ and $\mathrm{Fu}$ (1982) described a reticulate surface ornamentation, but did not comment on its fine structure. TEM analysis by Yin et al. (2005) subsequently demonstrated that the wall is made of interlocked polygonal plates $1-3 \mu \mathrm{m}$ wide, perforated by nanopores observed with SEM on both the exterior and interior vesicle surfaces (Kaufman and Xiao, 2003). The wall ultrastructure is multilayered (FIB-EM analyses; Schiffbauer and Xiao, 2009), and excystment by partial rupture or a circular opening (pylome) has also been observed (Yin et al., 2005).

Dictyosphaera macroreticulata is reported from the 1580-1460 Ma Lower Belt Group, USA (Adam, 2014), as well as the 1400-1700 Ma Ruyang and broadly correlative Gaoshanhe groups of China, where it co-occurs with abundant Shuiyousphaeridium macroreticulatum, an acanthomorph with similar wall ornamentation but bearing many processes (Xiao et al., 1997; Schiffbauer and Xiao, 2009). In the Chinese assemblages, Dictyosphaera specimens may include life cycle or taphonomic variants of Shuiyousphaeridium (Xiao et al., 1997) that either lost or never formed the outer wall layer from which processes arise (Javaux et al., 2004). The Chinese population includes vesicles ranging from 28 to $240 \mu \mathrm{m}$ in diameter, with 1-4 $\mu$ m platelets (Agic et al., 2015). In the Roper Group, however, D. macroreticulata $(=D$. delicata $)$ is rare and Shuiyousphaeridium absent. Dictyosphaera possibly occurs, as well, in the $\sim 1000 \mathrm{Ma}$ Stoer and lower Torridon groups, Scotland (Javaux, personal observation, 2008), although it is unnamed in Strother et al. (2011), who described a population as ellipsoidal fossils with walls made of highly ordered circular pits, creating a reticulate pattern and, therefore, differing from the plate-like wall structure of the Mesoproterozoic Dictyosphaera.

Kaufman and Xiao (2003) suggested that D. macroreticulata $(=D$. delicata $)$ was a photosynthetic eukaryote based on its complex morphology and C-isotopic composition. Neither morphology nor isotopic composition, however, is diagnostic with respect to energy metabolism, although the eukaryotic nature of this ornamented acritarch is convincing.
Functionally, D. macroreticulata is most likely a cyst or resting stage common to the life cycles of metabolically diverse eukaryotes (see below).

Recently, Tang et al. (2015) described a new species, D. tacita, based on two specimens that differ from the other species by their smooth external surface and the presence of hexagonal platelets only on the interior vesicle surface. The hexagons are smaller $(0.5-0.9 \mu \mathrm{m})$ and the vesicle diameter larger $(100-120 \mu \mathrm{m})$ than those of $D$. macroreticulata $(2-6 \mu \mathrm{m}$ platelets, $10-20 \mu \mathrm{m}$ vesicle diameter), $D$. sinica $(0.5-1.5 \mu \mathrm{m}$ platelets, 15-45 $\mu \mathrm{m}$ vesicle diameter), and $D$. delicata (1-3 $\mu \mathrm{m}$ platelets, 50-300 $\mu \mathrm{m}$ vesicle diameter). However, Agic et al. (2015) proposed a synonymy among $D$. delicata, D. macroreticulata, and other species of the genus based on the overlapping size range of the vesicles and wall platelets, and similar morphologies. Tang et al. (2015) argued that this needs reevaluation.

Genus Eomicrocystis Golovenok and Belova, 1986

Type species.-Eomicrocystis magilca Golovenok and Belova, 1986

Other species.-Eomicrocystis elegans Golovenok and Belova, 1986

Eomicrocystis magilca Golovenok and Belova, 1986

Figure 2.16-2.18

1986 Eomicrocystis magilca Golovenok and Belova, p. 95 [English version p. 89], pl. 7., figs. 5-7.

1989 Eomicrocystis magilca; Jankauskas et al., p. 91, pl. 19, fig. 7.

1994 Eomicrocystis magilca; Hofmann and Jackson, p. 25, pl. 18, figs. 2-4.

1997 Eomicrocystis magilca; Cotter, p. 258, fig. 7A, B.

2016 Eomicrocystis magilca; Baludikay et al., 2016, p. 179, fig. $12 \mathrm{f}$.

Holotype.-Eomicrocystis malgica Golovenok and Belova, 1986, pl. 7, fig. 5, from the Malgina Formation in the UchurMaya region, eastern Siberia.

Description.-Small ovoid or spheroidal colonies of light brown, loosely packed, small spheroidal to ovoid vesicles of uniform size, sometimes dividing by binary fission, without enclosing envelope. Three colonies observed, with cells $3 \mu \mathrm{m}$ wide and 6-7 $\mu \mathrm{m}$ long.

Occurrence.-Mesoproterozoic and early Neoproterozoic, Roper Group, Australia; Malgina Formation in the Uchur-Maya region, eastern Siberia (Golovenok and Belova, 1986); Bylot Supergroup, Canada (Hofmann and Jackson, 1994); Belt Supergroup, USA (Adam et al., 2016); Mbuyi-Mayi Supergroup, RDC (Baludikay et al., 2016).

Materials.-Three colonies in samples U5 $125.1 \mathrm{~m}$ from the Jalboi Formation and U6 $230.8 \mathrm{~m}$ from the Mainoru Formation.

Remarks.-Eomicrocystis differs from the genus Coleogleba (Strother et al., 1983) in lacking an organic matrix or distinct 
envelope enclosing the cell clusters, and from the genus Coniunctiophycus by the absence of a single dense mass less than a micron in diameter within cells, the smaller cell size $(10 \mu \mathrm{m}$ in $C$. sp), and the shape of the colony described in the Belt Supergroup as "spheroidal colony of tens of individuals, from which a wide, linear extension of more cells emerges and folds back onto itself to form a single reticulate fold" (Adam et al., 2016, p. 16). It also differs from described species of Myxococcoides (Schopf, 1968) in the size and organization of constituent cells. Eomicrocystis malgica differs from E. elegans by the smaller size of the cells' minimum diameter $(3-5 \mu \mathrm{m}$ versus 6-9 $\mu \mathrm{m}$ ) and more regular shape of the aggregate. The Roper colonies have cell diameters intermediate between the two species, but also have an irregular aggregate shape, and therefore are identified as E. malgica.

Genus Gemmuloides Samuelsson and Butterfield, 2001

Type species.-Gemmuloides doncooki Samuelsson and Butterfield 2001

cf. Gemmuloides doncooki Samuelsson and Butterfield, 2001 Figure 4.1

2001 Gemmuloides doncooki Samuelsson and Butterfield, p. 248, fig 7, D-F.

2014 Gemmuloides doncooki; Adam, p. 35, fig. 13.

Holotype.-Gemmuloides doncooki Samuelsson and Butterfield, 2001, p. 248, 249, GSC 117042 (Fig. 7D), Lone Land Formation, NW flank of Cap Mountain $\left(63^{\circ} 24^{\prime} 11^{\prime \prime N}\right.$, $\left.123^{\circ} 14^{\prime} 12^{\prime \prime} \mathrm{W}\right)$, Canada, approximately $2 \mathrm{~m}$ above carbonate ledge. Sample 94-LL-8. GSC loc. C-404520.

Description.-Two spheromorphs, 260 and $85 \mu \mathrm{m}$ diameter, with chagrinate wall were observed, each with a dark central sphere; only one shows evidence of budding. The presence of a dark central body is not included in the original description, but this may reflect taphonomic rather than systematic differences. The presence of a bud allies the Roper fossils with Gemmuloides doncooki.

Occurrence.-Roper Group, Australia; Lone Land Formation, Canada (Samuelsson and Butterfield, 2001); Belt Supergroup, USA (Adam, 2014).

Materials.-Two adjacent specimens in samples A82/3 $328.35 \mathrm{~m}$ from the Jalboi Member and U6 $240.2 \mathrm{~m}$ from the Mainoru Formation.

Remarks.-The Roper assemblage includes another budding spheromorph, Blastanosphaira kokkoda, which differs from cf. $G$. doncooki by its colonial habit, smaller diameter, thinner chagrinate wall with thin folds, and multiple buds of larger size relative to the mother cell, as well as by the presence of circular scars left by detached buds. Coneosphaera sp. in the Bylot Group (Hofmann and Jackson, 1994) has several smaller vesicles attached to a central one, resembling a specimen illustrated by Hermann (1990, p. 20, pl. 5.11) from the Miroedikha Formation, Siberia, which also differs from cf.
G. doncooki. Gemmuloides doncooki is also reported in the Belt Supergroup, Montana, USA (Adam, 2014).

Genus Leiosphaeridia Eisenack, 1958, emend. Downie and Sarjeant, 1963, emend. Turner, 1984

Type species._Leiosphaeridia baltica Eisenack, 1958.

Remarks.-Jankauskas (1989) revised the taxonomy of the genus Leiosphaeridia (see for detailed synonymy) and proposed an operational approach to species recognition within the genus Leiosphaeridia, essentially diagnosing species based on a combination of two characters: size and wall texture. Subsequent workers have tended to follow this scheme, with some modifications (e.g., Butterfield et al., 1994; Hofmann and Jackson, 1994). Jankauskas (1989) discriminated four smoothwalled Leiosphaeridia species: L. crassa and L. jacutica are thick-walled leiospheres, smaller or larger than $70 \mu \mathrm{m}$ in diameter, respectively; L. minutissima and L. tenuissima are thin-walled vesicles, again smaller or larger than $70 \mu \mathrm{m}$ in diameter, respectively. A fifth species, L. ternata differs from other species in having a distinctively rigid, opaque wall that fractures radially. Chuaria circularis is also a smooth-walled spheromorph, but can be discriminated from the leiospheres by its much thicker wall (at least $2 \mu \mathrm{m}$ thick), concentric folds and wrinkles, and large diameter $(0.43-3.5 \mathrm{~mm})$, leaving textured imprints on bedding surfaces (Butterfield et al., 1994).

The difficulty of applying the modified Jankauskas classification lies in the potential challenge of estimating wall thickness (underscored by Butterfield et al., 1994) and in classifying populations that do not fit neatly within the proposed size classes, as also noticed by Porter and Riedman (in press) in populations from the Neoproterozoic Chuar Group. Thus, while Butterfield et al. (2004) and Hofmann and Jackson (1994) reported a taxonomic break at $70 \mu \mathrm{m}$, there is little in the size frequency diagrams they present to justify this. Wall thickness has commonly been estimated on the basis of color or fold morphology, but wall color can vary as a function of taphonomy, thermal maturity, or original composition. Butterfield (in Butterfield et al., 1994, p. 11-12) has discussed the distinction between the thickness of folds and the thickness of the wall, which are not necessarily correlated. Previous study of wall ultrastructure in different Leiosphaeridia species from the Roper Group (Javaux et al., 2003, 2004) showed that L. crassa with thick lanceolate folds had a thinner wall than $L$. tenuissima with thin sinuous folds. We suggest that fold morphology, which reflects the taphonomy of walls with biological differences in flexibility, provides a more objective criterion than wall thickness or color. In this view, L. crassa and L. jacutica have thick lanceolate folds, whereas L. minutissima and L. tenuissima have thin sinuous folds.

Size frequency distribution presents a second complication, because many leiosphaerid populations transgress the $70 \mu \mathrm{m}$ boundary taken to separate species. For example, we measured the minimum diameter of specimens of different color (dark brown, medium brown, light brown) and fold morphology (broad lanceolate or thin sinuous folds) within the Roper assemblage and observed no size break around $70 \mu \mathrm{m}$ in these different morphotypes (Figs. 3.1-3.7, 4.4-4.8). This difficulty 

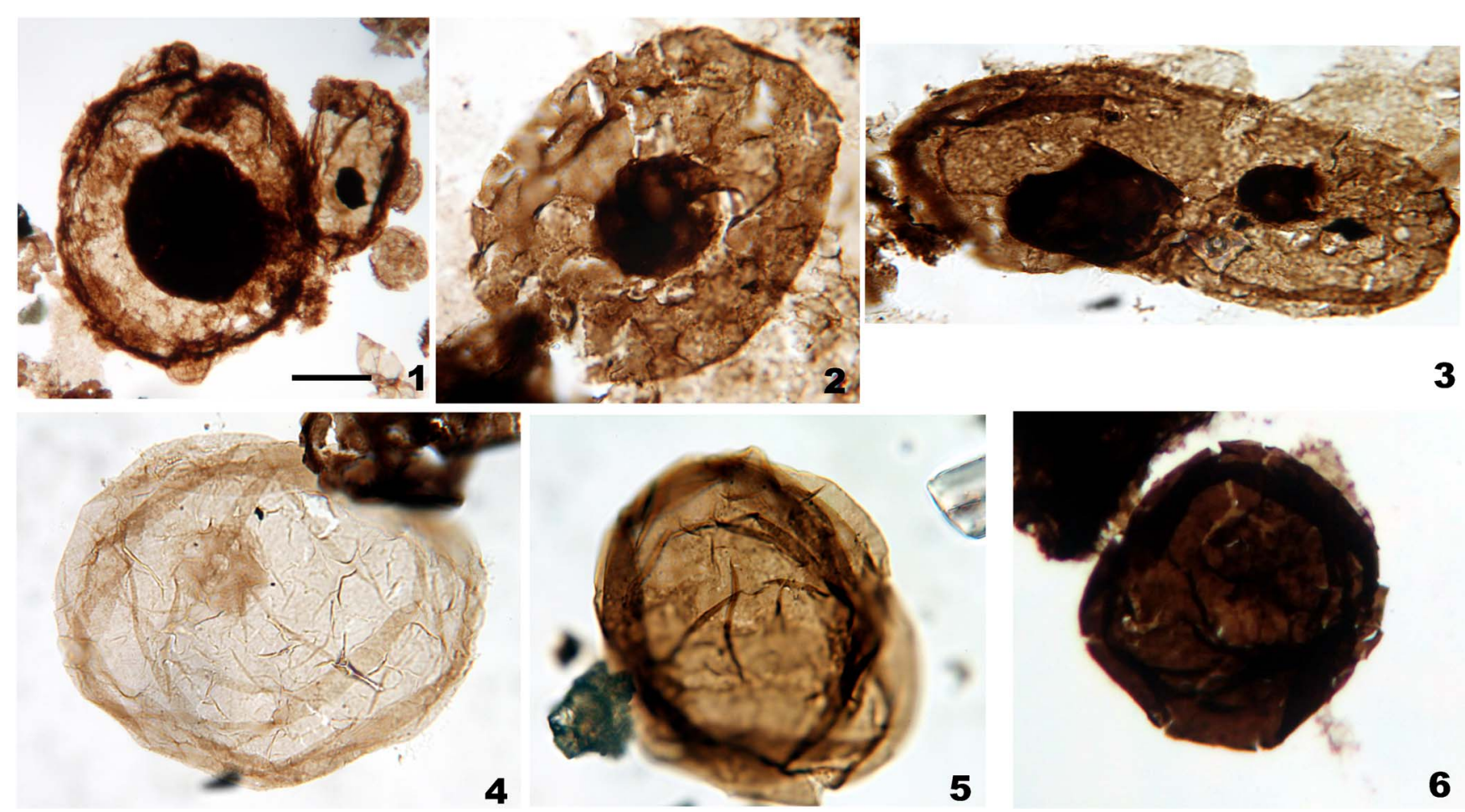

4
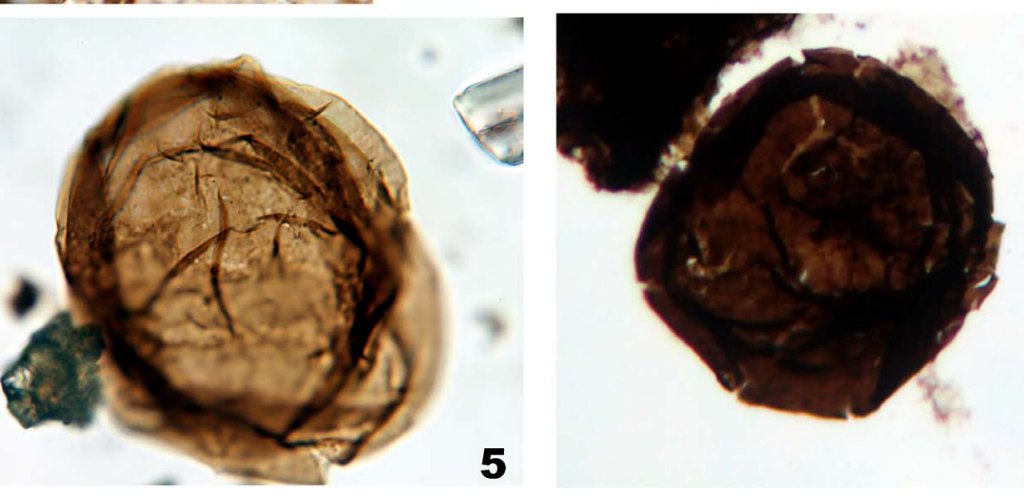

5

6
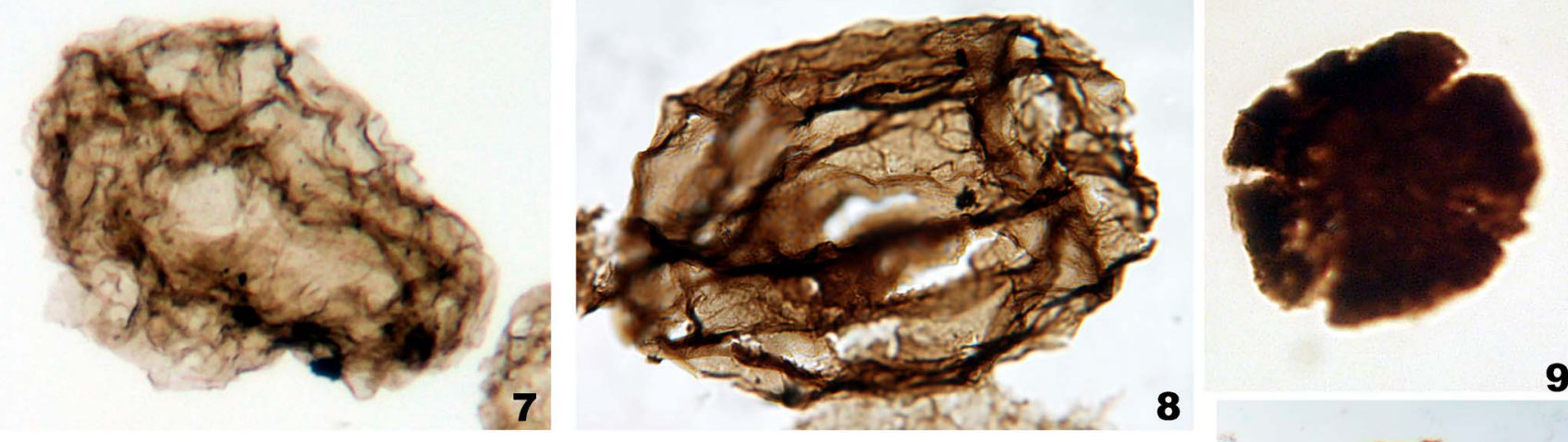

8

9
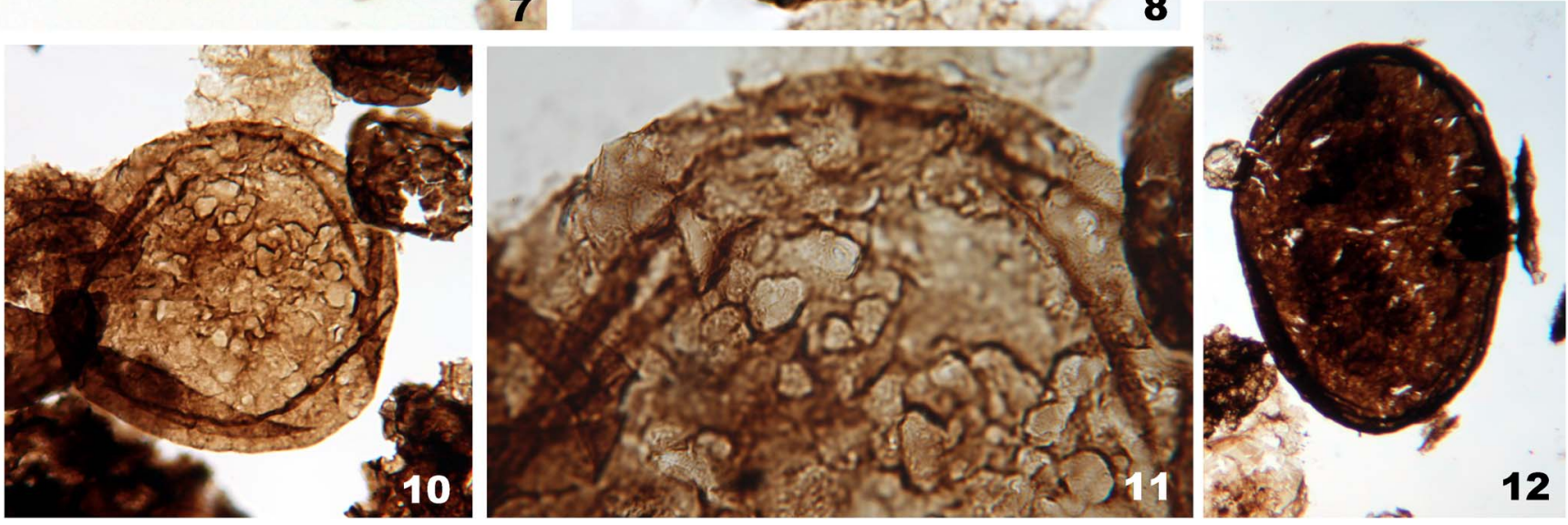

Figure 4. Photographs of Roper organic-walled microfossils (color figures are available in the online version of this paper): (1) cf. Gemmuloides doncooki. $(\mathbf{2}, \mathbf{3})$ Leiosphaeridia atava. (4) Light-brown Leiosphaeridia crassaljacutica. (5) Medium-brown Leiosphaeridia crassaljacutica. (6) Dark-brown Leiosphaeridia crassa/jacutica. (7) Light-brown Leiosphaeridia minutissimaltenuissima. (8) Medium-brown Leiosphaeridia minutissima/tenuissima. (9) Leiosphaeridia ternata. (10-12) Leiosphaeridia sp., (11) showing details of wall texture of specimen in (10). Scale bar in (1) is: (1) $85 \mu \mathrm{m} ;(\mathbf{2}) 12 \mu \mathrm{m} ;(\mathbf{3}) 15 \mu \mathrm{m} ;(\mathbf{4}) 14 \mu \mathrm{m} ;(\mathbf{5}) 17 \mu \mathrm{m} ;$ (6) $10 \mu \mathrm{m}$; (7-8) $6 \mu \mathrm{m}$; (9) $90 \mu \mathrm{m}$; (10) $30 \mu \mathrm{m}$; (11) $60 \mu \mathrm{m}$; (12) $10 \mu \mathrm{m}$. Slides and England coordinates are (1) U6 230.8 m .2 L2Y/1; (2) U6 305.1 m.2A O26 3/4; (3) U6 305.1 m.2A U37/1; (4, 7) U6 230.8 m .2 H46/G46 (area); (5) U6 240.2 m .2 O34/3; (6) U6 305.1 m .2A T26/1; (8) U6 305.1 m .2A U20; (9) U5 $125.1 \mathrm{~m} ;(\mathbf{1 0}, \mathbf{1 1}) \mathrm{U} 6305.1 \mathrm{~m} 2 \mathrm{~A}$ N20; (12) U6 $230.8 \mathrm{~m} .2 \mathrm{~S} 24 / 2$. 
has also been underlined by Porter and Riedman (2016) for Chuar Group populations. We suggest that species should be distinguished on the basis of modal rather than maximum diameter, so that Leiosphaeridia with lanceolate folds and a modal size $<70 \mu \mathrm{m}$ would be assigned to $L$. crassa, whereas populations with lanceolate folds and a modal size $>70 \mu \mathrm{m}$ would be placed in L. jacutica. This has the advantage of removing ambiguity in size frequency distributions while retaining the species distinctions used in many previous publications.

Based on the presence of a multilayered recalcitrant wall, Roper leiospheres have been interpreted as eukaryotic (Javaux et al., 2004). In the absence of supporting TEM analyses of wall ultrastructure, this attribution cannot be extended to all Proterozoic leiospheres; very likely the genus Leiosphaeridia is polyphyletic and their simple morphologies may record both prokaryotes and eukaryotes. Occasionally, medial split excystment structures have been observed in Roper specimens, suggesting that at least some of these fossils were resting cysts; however, even here, caution is advisable, because baeocyte-producing cyanobacterial cells can split in ways that resemble medial split excystment (Waterbury and Stanier, 1978, p. 13, fig. 4).

Leiospheres may occur as isolated specimens assigned to Leiosphaeridia, compact colonies called Synsphaeridium spp., or loose colonies named Symplassosphaeridium spp., possibly reflecting cyst and vegetative stages of the same population or life stages of different organisms. Single leiospheres might also be detached specimens from a colony (Hofmann and Jackson, 1994). The simple morphologies of leiospheres make it difficult to choose among these hypotheses, but more detailed analyses of wall ultrastructure and chemistry may provide the requisite tests (Javaux et al., 2004; Javaux and Marshall, 2006).

\section{Leiosphaeridia atava (Naumova, 1960) Jankauskas, Mikhailova, and Hermann, 1989}

Figure 4.2-4.3

1960 Megasacculina atava Naumova, pl. 3, fig. 15.

1989 Leiosphaeridia atava (Naumova, 1960); Jankauskas et al., p. 74, pl. 10, figs. 4-7.

2016 Leiosphaeridia atava; Sergeev et al., fig. 4.5.

Holotype.-Preparation 452/1, paleontological collection at the Institute of Precambrian Geology and Geochronology, St. Petersburg, Russia, upper Riphean (Tonian), Lakhanda Group, Neryuen Formation, Uchur-Maya region, Siberia. (The holotype was lost, as mentioned by Sergeev and Lee, 2006).

Occurrence.-The Mainoru Formation, Roper Group, Australia; the Lakhanda Group, Neryuen Formation, UchurMaya region, Siberia (Jankauskas, 1989); the Koltasy Formation, Russia (Sergeev et al., 2016); the El Mreiti Group, Taoudeni Basin, Mauritania (Beghin et al., in review).

Description.-Spheroidal to oval vesicle with a fine granular, flexible wall, with numerous folds, 46 to $56 \mu \mathrm{m}$ in diameter $(\mathrm{N}=4)$; two specimens with a dark, internal bleb of organic matter. No excystment structures observed.
Materials.-Four specimens observed in sample U6 $230.8 \mathrm{~m}$ from the Mainoru Formation.

Remarks.—Leiosphaeridia atava differs from L. obsuleta by its diameter larger than $70 \mu \mathrm{m}$ (Jankauskas, 1989).

Leiosphaeridia crassa (Naumauva, 1949), emend. Jankauskas in Jankauskas, Mikhailova, and Hermann, 1989

Figure 4.4-4.6

1949 Leiotriletes crassus Naumova, p. 54, pl. 1, figs. 5, 6; pl. 2, figs 5, 6 .

1989 Leiosphaeridia crassa; Jankauskas in Jankauskas et al., p. 75, pl. 9, figs. 5-10.

1989 Leiosphaeridia minutissima; Jankauskas et al., p. 75, pl. 9, figs. 2, 3 .

Holotype.-No holotype was designated by Naumova (1949), from the Lontova Formation, lower Cambrian, Estonia. A lectotype was designated by Jankauskas (in Jankauskas et al., 1989, p. 75) from Naumova (1949, pl. 1, fig. 3), but this specimen was part of Leiotriletes simplicissimus, which is a species that Jankauskas et al. (1989) synonymized with a different species of L. minutissima (Porter and Riedman, 2016).

Emended diagnosis.-A species of Leiosphaeridia with smooth, pliant walls with lanceolate folds and a modal diameter of less than $70 \mu \mathrm{m}$.

Occurrence.-Proterozoic and lower Paleozoic, worldwide.

Description.-Smooth-walled leiospheres with large lanceolate folds (Fig. 3.1-3.4). Minimum diameter ranges from 5 to $390 \mu \mathrm{m}$ (mean: $58.1 \pm 40.2 \mu \mathrm{m}, \quad \mathrm{N}=669$ ). No statistical differences among dark brown, medium, and light brown subpopulations, with mean diameters and standard deviations of, $54.5 \pm 21.6 \mu \mathrm{m}(\mathrm{N}=61), 55.3 \pm 30.7 \mu \mathrm{m}(\mathrm{N}=191 \mu \mathrm{m})$, and $56.0 \pm 27.7 \mu \mathrm{m}(\mathrm{N}=116)$. Excystment by partial rupture and medial split.

Materials.-These are the most common microfossils in the Roper assemblage, especially in samples U6 $305.1 \mathrm{~m}$ from the Mainoru Formation and U5 $125.1 \mathrm{~m}$ from the Jalboi Member.

Remarks.-As noted above, the rationale for emending the diagnosis of this species stems from the desire to focus on observed rather than inferred wall characters and to articulate size distinctions in a way that will minimize ambiguity in observed populations. The emended diagnosis considers the presence of lanceolate folds on a smooth wall as a diagnostic character as opposed to the wall color, which is not considered as a valid character.

Leiosphaeridia jacutica (Timofeev, 1966), emend. Mikhailova and Jankauskas in Jankauskas, Mikhailova, and Hermann, 1989 Figure 4.4-4.6

1966 Kildinella jacutica Timofeev, p. 30, pl. 7, fig. 2. 
1989 Leiosphaeridia jacutica (Timofeev, 1966); Mikhailova and Jankauskas in Jankauskas et al., 1989, p. 77, pl. 9, fig. 12; pl. 12, figs. 3, 6, 7, 9 .

Holotype.-Preparation number 452/1, Biostratigraphy Laboratory, Maya River Collection, late Mesoproterozoic/early Neoproterozoic Lakhanda Group, Russia (Timofeev, 1966, pl. 7, fig. 2).

Emended diagnosis.-A species of Leiosphaeridia characterized by smooth, pliant walls with lanceolate folds and a modal diameter greater than $70 \mu \mathrm{m}$.

\section{Occurrence.-Proterozoic worldwide.}

Description.-A species of Leiosphaeridia characterized by smooth, pliant walls with lanceolate folds and a modal diameter greater than $70 \mu \mathrm{m}$. Excystment by partial rupture and medial split. While we cannot exclude the possibility that these represent a long right-hand tail of the L. crassa population, we suspect that, by comparison to other mid-Proterozoic assemblages, distinct populations of large leiosphaerids were present in the Roper seaway.

Materials.-The Roper assemblage contains a relatively small proportion of very large, smooth walled leiosphaerids, in samples U6 $305.1 \mathrm{~m}$ and $240.2 \mathrm{~m}$ from the Mainoru Formation and sample GG1 $326.2 \mathrm{~m}$ from the Corcoran Formation.

Remarks.-As noted above, the rationale for emending the diagnosis of this species stems from the desire to focus on observed rather than inferred wall characters and to articulate size distinctions in a way that will minimize ambiguity in observed populations. The emended diagnosis considers the presence of lanceolate folds on a smooth wall as a diagnostic character, as opposed to wall color, which is not considered as a valid character.

Leiosphaeridia minutissima (Naumova, 1949), emend. Jankauskas in Jankauskas, Mikhailova, and Hermann, 1989

Figure 4.7-4.8

1949 Leiotreletes minutissimus Naumova, p. 52, pl. 1, figs. 1, 2; pl. 2, figs. 1, 2.

1989 Leiosphaeridia minutissima (Naumova); Jankauskas in Jankauskas et al., p. 79, pl. 9, figs. 1, 4, 11.

Lectotype.-No holotype was designated by Naumova (1949). Jankauskas (in Jankauskas et al., 1989, p. 80) designated a specimen of Leiotriletes minutissimus (pl. 1, fig. 1) from Naumova (1949) as lectotype.

Emended diagnosis.-A species of Leiosphaeridia characterized by smooth walls with sinuous folds and a modal diameter less than $70 \mu \mathrm{m}$.

Description.-Smooth-wall spheromorphs with sinuous folds and a modal diameter less than $70 \mu \mathrm{m}$. Minimum diameter
21-117 $\mu \mathrm{m}$ (mean: $50.6 \pm 18.2 \mu \mathrm{m}, \mathrm{N}=216$ ) (Figure 3.5-3.7). Light brown specimens $21-117 \mu \mathrm{m}$ in minimum diameter $(\mathrm{N}=116$, mean: $50.8 \pm 17.9 \mu \mathrm{m})$ and medium brown specimens $27-111 \mu \mathrm{m}(\mathrm{N}=47$, mean: $49.6 \pm 19.1 \mu \mathrm{m})$. No dark brown specimens observed.

Occurrence.-Proterozoic worldwide.

Materials.-Common in inshore facies of the Roper Group, especially in samples U6 $305.1 \mathrm{~m}$, and U6 $273.7 \mathrm{~m}$ from the Mainoru Formation.

Remarks.-As noted above, the rationale for emending the diagnosis of this species stems from the desire to focus on observed rather than inferred wall characters and to articulate size distinctions in a way that will minimize ambiguity in observed populations. The emended diagnosis considers the presence of sinuous folds on a smooth, thin wall as a diagnostic character, as opposed to wall color, which is not considered as a valid character.

Leiosphaeridia tenuissima Eisenack, 1958 emend. Figure 4.7-4.8

1958 Leiosphaeridia tenuissima Eisenack, p. 391, pl. 1, figs. 2, 3.

1989 Leiosphaeridia tenuissima; Jankauskas et al., p. 81, pl. 9, fig. 13.

Holotype.-Preparation A3, 3 number 4 from the Dictyonemashales of the lower Ordovician, St Petersburg area, Russia (Eisenack, 1958, pl. 1, fig. 2).

Emended diagnosis.-A species of Leiosphaeridia characterized by smooth walls with sinuous folds and a modal diameter (rather than maximum diameter) greater than $70 \mu \mathrm{m}$; the wall color is not a diagnostic criteria.

Description.-Smooth wall spheromorphs with sinuous folds and a modal diameter greater than $70 \mu \mathrm{m}$. These may reflect a larger, uncommon population of Leiosphaeridia in Roper shales.

Occurrence.-Proterozoic worldwide.

Materials.-Uncommon specimens in samples U6 $305.1 \mathrm{~m}$ and U6 $230.8 \mathrm{~m}$ from the Mainoru Formation.

Remarks.-As noted above, the rationale for emending the diagnosis of this species stems from the desire to focus on observed rather than inferred wall characters and to articulate size distinctions in a way that will minimize ambiguity in observed populations. The emended diagnosis considers the presence of sinuous folds on a smooth, thin wall as a diagnostic character as opposed to wall color, which is not considered as a valid character. 
Leiosphaeridia ternata (Timofeev, 1966), emend. Mikhailova and Jankauskas in Jankauskas et al., 1989

Figure 4.11

1966 Turuchanica ternata Timofeev, p. 45, pl. 9, fig. 8.

1989 Leiosphaeridia ternata (Timofeev); Mikhailova and Jankauskas in Jankauskas et al., p. 81, pl. 11, figs. 2-4; pl. 12 , figs. $4,5,8$.

2016 Leiosphaeridia ternata; Sergeev et al., fig. 4.3, 4.4.

Holotype.-Preparation 169/1, Biostratigraphical laboratory LAGED AN SSSR, Turukhansk collection, lower Tungunska, Turukhansk district; Miroedikhinsk series, Riphean (Mesoproterozoic and early Neoproterozoic boundary), rarely Ordovician (Timofeev, 1966).

Occurrence.-Found globally in worldwide Proterozoic successions.

Description.-Compressed opaque spheromorph with thick, rigid walls commonly showing characteristic radial fractures. Diameter 15 to $110 \mu \mathrm{m}$.

Materials.-A few specimens were observed in samples A82/3 $157.5 \mathrm{~m}$ in the Jalboi Member, GG1 $326.2 \mathrm{~m}$ in the Corcoran Formation, and U6 $305.1 \mathrm{~m}$ in the Mainoru Formation.

Leiosphaeridia sp.

Figure 4.10-4.12

Description.-Large medium to dark brown spheroidal to oval vesicles with a characteristic cork-like wall texture made of 5-11 $\mu \mathrm{m}$, irregular patchy areas of different colors and fabric; this texture may well be taphonomic, but if so, it reflects original differences in wall composition, compared to other leiosphaerids. Concentric folds at the periphery. The minimum diameter of 19 spheroidal specimens is $56-455 \mu \mathrm{m}$ (mean: $159.8 \pm 96.3 \mu \mathrm{m})$. Three oval specimens measured $75-210 \mu \mathrm{m}$ wide and $160-330 \mu \mathrm{m}$ long.

Materials.-22 specimens in the Gibb Member, samples U6 $305.1 \mathrm{~m}$, U6 $230.8 \mathrm{~m}$ of the Mainoru Formation, and in sample GG1 $171.5 \mathrm{~m}$ of the Corcoran Formation.

Remarks.-This species differs from another large leiosphere L. jacutica by its particular cork-like wall texture and a morphology that ranges from spheroidal to ovoidal. It also differs from Chuaria circularis, which has a thicker opaque, smooth wall. These specimens are left in open nomenclature until further characterization by SEM and TEM.

Genus Lineamorpha Vorob'eva, Sergeev, and Yu, 2015

Type species.—Lineamorpha elongata Vorob'eva, Sergeev, and $\mathrm{Yu}, 2015$, by monotypy.

Lineamorpha elongata Vorob'eva et al., 2015

Figure 5.1-5.4
2004 "large striated tubes" Javaux et al., p. 126, fig 3 g-k.

2015 Lineamorpha elongata; Vorob'eva et al., p. 216, figs. 7 $1-7.5$.

2016 Lineamorpha elongata; Adam et al., fig. 9 A-D.

Holotype.-Figure 7.4, Vorob'eva et al., 2015, GINPC 14711-804, locality AK-14, Kotuikan River valley, Kotuikan Formation, Anabar Uplift, northern Siberia.

Occurrence.-Early Mesoproterozoic, Jalboi, Crawford, and upper Mainoru formations, Roper Group, Australia; Belt Supergroup, Montana, US (Adam, 2014); and Kotuikan Formation, northern Siberia (Vorob'eva et al., 2015).

Description.-Longitudinally striated hollow tubes (not a sheath around bundled filamentous sheaths) that often break into fragments, so maximum length is unknown but millimetric, 34 to $150 \mu \mathrm{m}$ in diameter, fragment length: 131 to $473 \mu \mathrm{m}$ $(\mathrm{N}=25)$.

Materials.-562 specimens observed in maceration, in lowershoreface to inner shelf facies of the Jalboi, Crawford, and upper Mainoru formations, Roper Group; one observed in thin section, 25 measured specimens. Abundant specimens observed in samples U5 $125.1 \mathrm{~m}$ and U5 $151.3 \mathrm{~m}$ of the Jalboi Member; in samples U5 $334.3 \mathrm{~m}$ and U5 $412.1 \mathrm{~m}$ of the Arnold sandstone Member; in samples A82/3 $311 \mathrm{~m}$ of the Crawford Formation; and in samples U6 $305.1 \mathrm{~m}$, U6 $230.8 \mathrm{~m}$, and U6 $240.2 \mathrm{~m}$ from the basal Mainoru Formation, but rare elsewhere.

Remarks.-In the Roper population, there seems to be no relation between diameter and fragment length, nor dominant fragment length, suggesting random fragmentation of longer, probably millimetric, tubes. Light microscopy shows longitudinal, micron-scale striations along the tubes while SEM reveals a thick multilayered wall of densely packed granules, but no longitudinal striations. At the ultrastructural level (TEM), however, transverse sections of the wall show a clear alternation of electron-dense and electron-tenuous bands that correspond in size and distribution to the striations observed by light microscopy (Javaux et al., 2004). The wall is $\sim 1 \mu \mathrm{m}$ thick, occasionally with an outer, electron-dense layer. The striations, thus, are not wall sculpture, but reflect original compositional heterogeneities in the tube wall, indicating complex physiological controls on wall formation.

The Roper material appears to be indistinguishable from the type of Lineaforma elongata from the lower Mesoproterozoic Kotuikan Formation, northern Siberia (Vorob'eva et al., 2015). In the Roper Group, these filaments occur as transported fragments, contributing less than $3 \%$ to the entire assemblage, but up of $40 \%$ in lower-shoreface to innershelf shales. The rounded, closed tube ends observed in the Russian population were not observed in fragmental Roper specimens. The large size and complex wall ultrastructure of these microfossils suggest a eukaryotic affinity (Javaux et al., 2004). 

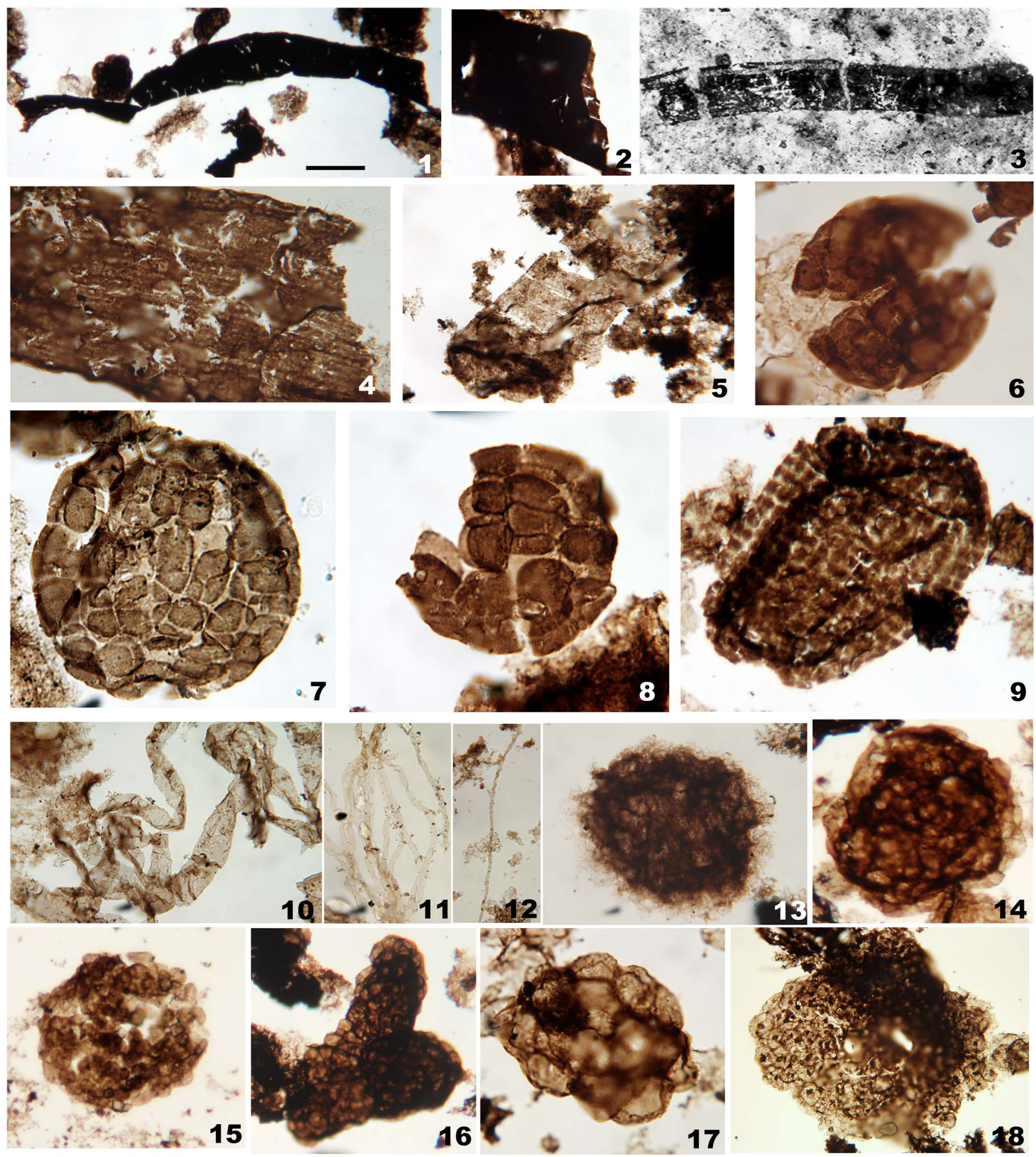

Figure 5. Photographs of Roper organic-walled microfossils: (1-4) Lineaforma lineata: (2) showing hollow extremity of specimen in (1), (3) specimen in situ in thin section. (5) Paleolyngbya catenata. (6-9) Satka favosa: (6) showing medial split and hollow interior, (8) showing hollow interior. (10) Siphonophycus kestron (bottom specimen) and S. typicum (top specimen). (11) Siphonophycus robustum. (12) Siphonophycus septatum. (13) Siphonophycus thulenema. (14) Squamosphaera colonialica. (15) Symplassophaeridium sp, (16-18) Synsphaeridium spp. Scale bar in (1) is: (1) $60 \mu \mathrm{m} ;(\mathbf{2}) 100 \mu \mathrm{m} ;($ (3) $50 \mu \mathrm{m}$; (4) $110 \mu \mathrm{m}$; $(\mathbf{5 , 7}) 15 \mu \mathrm{m} ;(\mathbf{6 , 8}) 20 \mu \mathrm{m}$; (9) $40 \mu \mathrm{m} ;(\mathbf{1 0}, \mathbf{1 3}) 20 \mu \mathrm{m}$; (11, 12) $10 \mu \mathrm{m}$; (14) $50 \mu \mathrm{m} ;(\mathbf{1 5}, \mathbf{1 6}) 33 \mu \mathrm{m} ;(\mathbf{1 7}, \mathbf{1 8}) 15 \mu \mathrm{m}$. Slides and England coordinates are $(\mathbf{1}, \mathbf{2})$ U5 $125.1 \mathrm{~m} \mathrm{C} 13 / 3$; (3) thin section 3785a R47/1; (4) A82/3 328.35 m.3 N41/4; (5) U5 130.5 ker E21; (6) U6 240.8 m .2 K23/3; (7) U6 305.1 m . E29; (8) U6 230.8 m.2 F14; (9) U6 230.8 m .2 J26/4; (10) U6 240.2 m .2 Z27/2; (11) U5 125.1 m .2 X48/4; (12) GG1 340.2 m.3 M13; (13) U6 240.2 m .2 Q18/3; (14) A82/3 328.35 m .3 K/L35; (15) A82/3 311.3 m .2 O5/2; (16) U5 125.1 m .2 R34/3; (17) A82/3 311.3 m .2 H40/4; (18) U5 151.3 m .2 Q/R29. 
Genus Palaeolyngbya Schopf, 1968

Type species.—Palaeolyngbya barghoorniana Schopf, 1968

Palaeolyngbya catenata Hermann, 1974

Figure 5.5

1974 Palaeolyngbya catenata Hermann, p. 8, pl. 6, fig. 5.

1980 Oscillariopsis robusta; Horodyski and Donaldson, p. 149 , fig. $13 \mathrm{H}$.

1994 Palaeolyngbya catenata; Butterfield et al., 1994, p. 61, fig. $25 \mathrm{~F}-\mathrm{G}$.

Holotype.-No holotype designated by Hermann, 1974, p. 8, 9, pl. 6, fig. 5, Tonian, Miroedikha Formation, Russia.

Description.-Cellular trichome within a single encompassing sheath, cells $26 \mu \mathrm{m}$ wide and $6 \mu \mathrm{m}$ long.

Materials.-One fragmented specimen with ripped sheath in sample U5 $130.5 \mathrm{~m}$ from the Jalboi Member.

Genus Satka Jankauskas, 1979a

Type species.—Satka favosa Jankauskas, 1979a

Satka favosa Jankauskas, 1979a

Figure 5.6-5.9

1979a Satka favosa Jankauskas, pl. 4, fig. 2.

1980 "polygonally segmented sphaeromorphs" Horodyski, p. 658, pl. 2, figs. 8-12.

1989 Satka favosa; Jankauskas et al., p. 51, pl. 4, figs. 1, 2?

1989 Satka elongata; Jankauskas et al., p. 51, pl. 4, figs. 3, 5.

1989 Satka granulosa; Jankauskas et al., p. 51, pl. 4, fig. 8.

1994 Satka spp. Hofmann and Jackson, pl. 18, figs. 26-31.

2001 Satka favosa; Javaux et al., pl. 1e, f.

2003 Satka favosa; Javaux et al., figs. 1-10, 11.

2004 Satka favosa; Javaux et al., 2004, p. 125, fig. 3a-f.

Holotype.-Specimen pl. 4, fig. 2, preparation 16-1815-635, lower and middle Riphean (Mesoproterozoic) successions of the southern Urals, Russia (Jankauskas, 1989).

Description.-Hollow oval spheromorph, 24 to $100 \mu \mathrm{m}$ wide and 29 to $100 \mu \mathrm{m}$ long $(\mathrm{N}=122)$, with walls made of tessellated 6 to $16 \mu \mathrm{m}$ (minimum diameter) polygonal plates and with no external envelope. Excystment by medial split (Fig. 5.6).

Occurrence.-Satka favosa, as described here, seems to be restricted to Mesoproterozoic rocks, including lower Mesoproterozoic shales of the Belt Supergoup ("polygonally segmented sphaeromorphs" of Horodyski, 1980; Adam, 2014), the Bylot Supergroup of the Canadadian Arctic (Hofmann and Jackson, 1994, as Satka spp., pl. 18, figs. 26-31), and lower and middle Riphean (Mesoproterozoic) successions of the southern Urals (Jankauskas et al., 1989).
Materials.-Many specimens observed in shoreface facies of the Gibb Member, basal Mainoru Formation (samples U6 240.2 m, U6 273.7 m, U6 $305.1 \mathrm{~m}$ ), but rare elsewhere.

Remarks.-The wall construction of S. favosa identifies it as a eukaryote, most likely the resting stage of some protist. Great confusion exists in the literature concerning Satka and its species. Jankauskas (1989) differentiated S. favosa from S. elongata $(40-70 \mu \mathrm{m})$ by its smaller size and the characteristic shape of its inward-curving plates; S. colonialica (up to $150 \mu \mathrm{m}$ ) was segregated because of its simpler regular shape and betterdefined plates; and $S$. granulosa $(40-50 \mu \mathrm{m}$ wide to $75-125 \mu \mathrm{m}$ long) was differentiated by its smaller size and granular appearance (linked to the presence of internal bodies). The specimens illustrated by Jankauskas (1989) as Satka elongata (pl. 4, figs. 3, 5) and Satka granulosa (pl. 4, fig. 8) also resemble Satka favosa as described here. Satka squamifera is described as having rounded plates and an external envelope. From our observations, however, the "plates" of S. squamifera represent the imprints of spheroidal cells on an encompassing envelope; therefore, we interpret this population as a colonial microorganism, perhaps cyanobacterial, which is unlikely to be linked to $S$. favosa at the domain level, and recently placed within the new genus Squamosphaera (Tang et al., 2015).

Genus Siphonophycus Schopf, 1968, emend. Knoll, Swett, and Mark, 1991

Type species.-Siphonophycus kestron Schopf (1968).

Occurrence.-Widespread in Proterozoic assemblages, common throughout the Roper Group.

Description.-Fragments of smooth, non-septate tubes, commonly interpreted as the sheaths of oscillatorialean cyanobacteria.

Remarks.-Different species are distinguished on the basis of cross-sectional diameter (revision in Butterfield et al., 1994): S. thulenema: $0.5 \mu \mathrm{m} ; S$. septatum: $1-2 \mu \mathrm{m} ; S$. robustum:

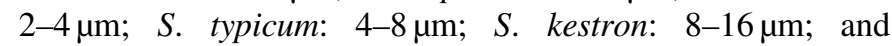
S. solidum: $16-32 \mu \mathrm{m}$. Five species occur in Roper shales: S. kestron, S. robustum, S. septatum and S. typicum occur as transported fragments; and $S$. thulenema forms small balls of thin filamentous sheaths. Siphonophycus spp. are commonly interpreted as the sheaths of oscillatorialean cyanobacteria.

\section{Siphonophycus kestron Schopf, 1968} Figure 5.10

1968 Siphonophycus kestron Schopf, p. 671, pl. 80, figs. 1-3. 1971 Siphonophycus kestron; Schopf and Blacic, pl. 109, figs. 3, 4.

1992 Siphonophycus kestron; Sergeev, p. 95, pl. 16, figs. 8, 9. 1992 Siphonophycus kestron; Schopf, pl. 31, fig. J.

1994 Siphonophycus kestron; Butterfield et al., fig. 21D.

2001 Siphonophycus kestron; Sergeev and Lee, p. 8, pl. 1, fig. 1. 
2006 Siphonophycus kestron; Sergeev and Lee, pl. 1, fig. 10. 2006 Siphonophycus kestron; Sergeev, p. 214, pl. 22, figs. 1, 2 ; pl. 28, fig. 3; pl. 36, fig. 3; pl. 44, fig. 11 ; pl. 45 , figs. 3,6 .

Holotype.-Specimen pl. 80, fig. 1 (Schopf, 1968), thin section Bit. Spr. 6-3, Paleobotanical Collections, Harvard University number 58469, from Neoproterozoic Bitter Springs Formation, Amadeus Basin, Australia.

Description.-Fragments of smooth, non-septate tubes, 8$16 \mu \mathrm{m}$ in diameter, most specimens $8-9 \mu \mathrm{m}$, a few up to $16 \mu \mathrm{m}$.

Materials.-Dozens of filamentous sheaths, abundant in samples GG1 $340.2 \mathrm{~m}$ of the Corcoran Formation, a few in sample GG1 $48.75 \mathrm{~m}$ from the Velkerri Formation.

\section{Siphonophycus robustum (Schopf, 1968) Knoll,} Swett, and Mark, 1991

Figure 5.11

1968 Eomycetopsis robusta Schopf, p. 685, pl. 82, figs. 2-3; pl. 83, figs. 1-4.

1991 Siphonophycus robustum; Knoll et al., p. 565, fig. 10.3, 10.5.

1994 Siphonophycus robustum; Butterfield et al., p. 64, figs. 26A, G.

Holotype.-Specimen pl. 83, fig. 1 (Schopf, 1968), thin section Bit. Spr. 10-1, Paleobotanical Collections, Harvard University number 58491 from Neoproterozoic Bitter Springs Formation, Amadeus Basin, Australia.

Description.-Smooth filamentous sheaths $2-4 \mu \mathrm{m}$ in diameter, most specimens $2-3 \mu \mathrm{m}$ in diameter.

Materials.-Dozens of specimens, most abundant in sample GG1 $340.2 \mathrm{~m}$ of the Corcoran Formation and sample U6 $240.6 \mathrm{~m}$ of the Mainoru Formation.

\section{Siphonophycus septatum (Schopf, 1968) Knoll,} Swett, and Mark, 1991

Figure 5.12

1968 Tenuofilum septatum Schopf, p. 679, pl. 86, figs. 10-12. 1991 Siphonophycus septatum; Knoll et al., p. 565, fig. 10.2.

Holotype.-Specimen pl. 86, fig. 11 (Schopf, 1968), thin section Bit/Spr 6-3, Paleobotanical collections, Harvard University, number 58527 from the Neoproterozoic Bitter Springs Formation, Amadeus Basin, Australia.

Description.-Fragments of smooth, non-septate tubes, 1-2 $\mu \mathrm{m}$ in diameter. Common, as transported fragments.

Materials.-Common in the Roper Group, abundant in sample U5 $508.6 \mathrm{~m}$ of the Mainoru Formation.

Siphonophycus thulenema Butterfield, Knoll, and Swett, 1994 Figure 5.13
1994 Siphonophycus thulenema Butterfield et al., fig. 22I.

Siphonophycus thulenema Butterfield, Knoll, and Swett, 1994, fig. 22I

Holotype.-HUPC 62718, fig. 22I, slide 86-G-62-46, R-28-3, Algal Dolomite Member, Svanbergfjellet Foramtion, Geerabukta $\left(79^{\circ} 35^{\prime} 30^{\prime \prime} \mathrm{N}, 17^{\circ} 44^{\prime \prime} \mathrm{E}\right), 55 \mathrm{~m}$ above base of member.

Description.-Fragments of thin, smooth, non-septate tubes, $0.5 \mu \mathrm{m}$ in diameter, forming small balls of enrolled filamentous sheaths.

Materials.-Rare, in sample U5 $125.1 \mathrm{~m}$ of the Jalboi Member.

Siphonophycus typicum (Hermann, 1974), Butterfield, Knoll, and Swett, 1994

Fig. 5.10

1974 Leiothrichoides tipicus Hermann, p. 7, pl. 6, figs. 1-2.

1994 Siphonophycus typicum; Butterfield et al., p. 66, figs. 23B-D, 26B, H, I.

Holotype.-Specimen pl. 6, figs. 1, 2 (Hermann, 1974), preparation number 49/2T, Neoproterozoic Miroyedikha Formation, Krasnoyarsk Krai in Turukhansk region, near Maya River, Siberia.

Description.-Fragments of thin smooth, non-septate tubes, 4-8 $\mu \mathrm{m}$ in diameter.

Materials.-Common; most abundant in samples U5 $508.6 \mathrm{~m}$ of the Mainoru Formation, GG1 $46.75 \mathrm{~m}$ of the Velkerri Formation and GG1 $340.2 \mathrm{~m}$ of the Corcoran Formation.

Genus Squamosphaera Tang et al., 2015

Type species.-Squamosphaera colonialica (Jankauskas, 1979b) Tang et al., 2015 by monotypy

Squamosphaera colonialica (Jankauskas, 1979b)

Tang et al., 2015

Figure 5.14

1979b Satka colonialica Jankauskas, p. 192, pl. 1, figs. 4, 6. 1985 Satka colonialica; Knoll and Swett, p. 468, pl. 53, figs. 4-6, 8.

1989 Satka colonialica; Jankauskas et al., p. 51, pl. 4, figs. 4, 7 .

1989 Satka squamifera; Jankauskas et al., p. 52, pl. 4, fig. 10; pl. 5, fig.1-8

1997 Satka colonialica; Samuelsson, p. 175, fig. 9A, B.

1999 Satka colonialica; Cotter, p. 77, fig. 7C.

1999 Satka colonialica; Samuelsson et al., fig. 4G.

2015 Squamosphaera colonialica; Tang et al., 2015, p. 312, fig. 12 A-C2, fig. 13 A-F2

in press Squamosphaera colonialica; Porter and Riedman, fig. 17, 1-7. [See for complete synonymy] 
Holotype.-Number 16-62-4762/22, slide 1. Well Kabakovo62, 4762-4765 m. Neoproterozoic Zigazino-Komarovo Formation, Ufa, Bashkirian Urals (Jankauskas, 1979, fig. 4).

Description.-Single-walled, spheroidal, tomaculate, or irregularly shaped vesicles with irregular outline characterized by numerous broadly domical bulges. Vesicles $29-166 \mu \mathrm{m}$ wide and $66-184 \mu \mathrm{m}$ long $(\mathrm{N}=37)$; individual bulges 11 to $14 \mu \mathrm{m}$ in diameter.

Materials.-Many specimens were observed in all facies except the most basinal and are particularly abundant in the lowershoreface to storm-dominated shelf facies of the Jalboi Member and Crawford Formation (samples A82/3 $311 \mathrm{~m}, \mathrm{~A} 82 / 3166 \mathrm{~m}$, U5 $125.1 \mathrm{~m}$, U5 $151.3 \mathrm{~m}$, U5 $334.3 \mathrm{~m}$, U5 $412.1 \mathrm{~m}$ ).

Remarks.-The Roper population closely matches the emended diagnosis provided by Porter and Riedman (in press). Populations assigned here to the genus Squamosphaera were originally classified as a species of the genus Satka (Jankauskas, 1979b). As discussed above, the type species of Satka, S. favosa, is characterized by a wall of tessellated plates, which is far different from the vesicles observed in S. colonialica. The two species should not be placed in the same genus and doubtfully belong to the same domain. Tang et al. (2015) gave formal recognition to this by segregating populations of Satka colonialica into the new genus. Tang et al.'s (2015) diagnosis and description suggest that Squamosphaera was a cyst wall ornamented by broadly domical processes, but this conflicts with the irregular morphology of individual vesicles, both within Tang et al.'s (2015) illustrated materials and populations observed elsewhere. For this reason, Porter and Riedman (in press) emended the diagnosis of Squamosphaera, identifying the domical surface features simply as bulges. Roper populations closely resemble those from the Chuar Group, and we interpret them as enveloped marked by imprints of internal cells no longer present.

Hofmann and Jackson (1994, p. 28) described Satka colonialica from the Bylot Supergroup, the Canadadian Arctic, as a colony of packaged cells in "distinct belt-like rows transverse to the long axis of the colony," with a smooth surface and distinct curvilinear folds. They further suggested that $S$. squamifera, $S$. granulosa, and $S$. elongata might be taphonomic variants of the same taxon, and mentioned S. elongata Jankauskas, 1989 as the senior synonym to which other species should be referred. Satka favosa, however, is actually the senior species of the genus Satka (Jankauskas, 1979b). Hofmann and Jackson (1994) also include in their suggestion of synonymy a Bylot population referred to Satka spp. that we interpret as S. favosa (see above). Several types of coccoidal cyanobacteria (Chroococcales and Pleurocapsales) and green algae (such as Pandorina) can produce colonies of packed spheroidal cells embedded in an envelope of amorphous mucilage matrix. Less commonly, the individual cells have a single wall rather than a multilamellate envelope, are closely packed, and the colony is surrounded in a structurally defined envelope, such as in modern cyanobacteria that produce baeocytes (endospores) within a parental wall (Chroococcidiopsis and Staniera/Dermocarpa).
Squamosphaera colonialica resembles these pleurocapsalean cyanobacteria, with the internal cells not preserved, only their imprints on the wall. Squamosphaera differs from Synsphaeridium spp., which are colonies without an envelope.

\section{Genus Symplassosphaeridium Timofeev, 1959 Symplassosphaeridium $\mathrm{sp}$. Figure 5.15}

Description.-Aggregates of loosely packed, smooth-walled vesicles of variable size, but with similar morphology and size within a colony. Differs from Synsphaeridum by the loose packing of vesicles.

Materials.-Dozens of colonies observed.

Genus Synsphaeridium Eisenack, 1965

Type species.—Synsphaeridium gotlandicum Eisenack, 1965.

Synsphaeridium sp.

Figure 5.16-5.18

Occurrence.-Widespread in Proterozoic and Phanerozoic rocks.

Description.-Aggregates of contiguous smooth-walled vesicles, sometimes with internal inclusions, without envelope. Vesicles are similar in morphology and size within a colony. Colonies have variable size, from broadly spherical to elongated and irregular. Cell diameter ranges from 4 to $40 \mu \mathrm{m}$, and colonies can be up to $180 \mu \mathrm{m}$ or more in diameter.

Materials.-Dozens of colonies observed, especially in samples GG1 $326.2 \mathrm{~m}$, in the Corcoran Formation and in samples U5 $125.1 \mathrm{~m}$ and U5 $151.3 \mathrm{~m}$ of the Jalboi Member.

Genus Tappania Yin, 1997

Type species.-Tappania plana Yin, 1997.

Other species.-Tappania tubata Yin, 1997; Tappania gangaei Prasad and Asher, 2001.

Tappania plana Yin, 1997

Figure 6.1-6.15

1997 Tappania plana Yin, p. 23, pl. 1, figs. 4, 6, 7.

1997 Tappania tubata Yin, p. 23, 24, pl. 2, figs. 1, 3, 4, 6.

1997 Tappania plana; Xiao et al., p. 205, fig. 3c.

2001 Tappania plana; Prasad and Asher, p. 73, pl. 2, figs. 1-3, 9; pl. 3, figs. 1-6.

2001 Tappania tubata; Prasad and Asher, p. 74, pl. 2, figs. 4-7.

2001 Tappania gangaei; Prasad and Asher, p. 74, pl. 2, figs. 8, 10.

2001 Tappania plana; Javaux et al., pl. 1a-c.

2004 Tappania plana; Javaux et al., p. 124, fig. 2a-e.

2009 Tappania plana; Nagovitsin, fig. 2 a-e. 


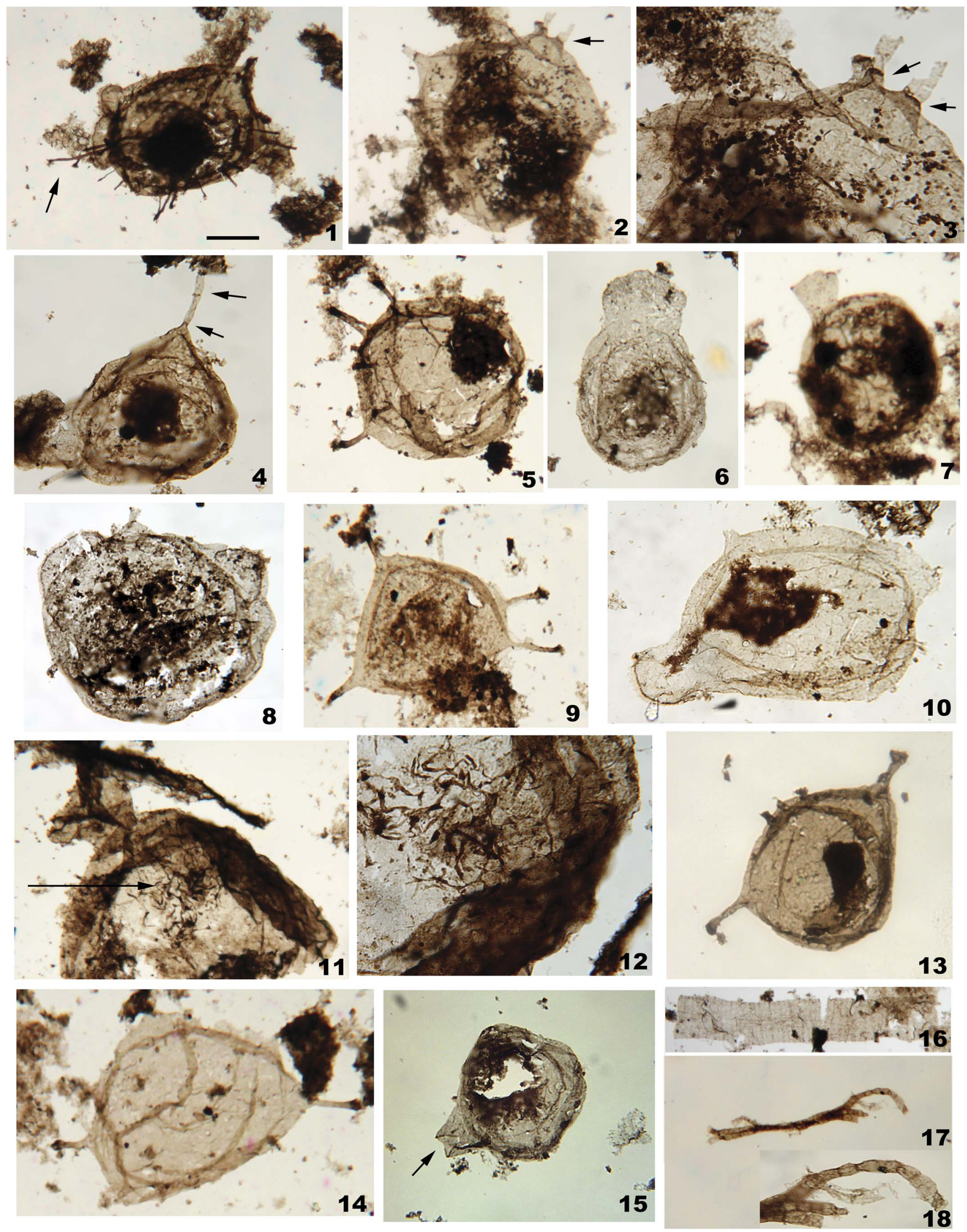


Holotype.-Sample and slide M 9208-1, L4/37, Shuiyou section, southern Shanxi, North China; lower shales of Beidajian Formation of the Ruyang Group (Meso-Neoproterozoic) (Yin, 1997, pl. 1, fig. 7).

Description.-Size 15 to $158 \mu \mathrm{m}(\mathrm{N}=48)$, irregularly spheroidal vesicle bearing zero to 21 tubular, heteromorphic, sometimes branching, sometimes septate processes with closed relatively dark, rounded ends; zero to four neck-like expansions; zero to three bulbous protrusions. Process length up to $8 \mu \mathrm{m}$; bulbous expansions $2 \mu \mathrm{m}$ wide; neck up to $2 \mu \mathrm{m}$ high and $2 \mu \mathrm{m}$ wide; two specimens show septate processes (Fig. 6.2-6.4), two others with branching processes. One specimen with a neck-like expansion shows a concentration of small $(\sim 8 \mu \mathrm{m}$ long) processes with dark ends in one area of the vesicle surface, and another has small (3-5 um long), hair-like spines, which are probably developing processes (not shown). The vesicle occasionally includes a dark cytoplasmic remnant. Specimens may bear only broad neck-like extensions (Fig. 6.6, 6.7, 6.10), or only processes (zero to 21) (Fig. 6.2, 6.5, 6.9, 6.13), or both. Neck-like extensions usually have a dark rim. In one specimen without processes, this trapezoidal extension is open, possibly indicating excystment (Fig. 6.15). Some specimens also show bulbous expansions suggestive of division by budding (Fig. 6.1); buds have semi-circular to oval convex morphology, whereas neck-like expansions have a trapezoidal shape, with side walls flaring outward and a convex end.

Occurrence.-Tappania plana seems to be restricted to uppermost Paleoproterozoic and Mesoproterozoic rocks, including, in addition to the Roper Group, Australia (Javaux et al., 2001); the Ruyang Group, China (Xiao et al., 1997; Yin, 1997); the Bahraich and Kheinjua groups, India (Prasad and Asher, 2001; Prasad et al., 2005); the Kamo Group of Siberia (Nagovitsin 2009; Nagovitsin et al., 2010); and the Lower Belt Group, USA (Adam, 2014).

Materials. - 48 specimens measured in samples, U5 $151.3 \mathrm{~m}$ and U5 $130.5 \mathrm{~m}$ from the Jalboi Formation (proximal shelf facies), and from GG1 $340.2 \mathrm{~m}$ and GG1 $326.2 \mathrm{~m}$ from the Corcoran Formation (TST, distal shelf facies).

Remarks.-We observed a wide range of morphologies within Tappania, ranging from specimens with only broad, neck-like extensions, or only processes, to individuals with both broad, neck-like extensions and processes. On one fragmented specimen bearing a neck-like expansion, very small processes with dark, rounded closed ends are locally grouped on the vesicle wall. This is the first time this morphology has been reported in Tappania plana, however a single fragmented specimen and the large variability of the species precludes the creation of a new species at this time. Rare specimens show processes with septa, suggesting Tappania was multicellular. Ultrastructural analyses show a unilayered homogenous wall (Javaux et al., 2004). The Roper population shows division by budding, and possible excystment through the opening of a neck-like extension. Specimens from the Kotuikan Formation illustrated by Nagovitsin (2009) suggest that Tappania could also reproduce by a simple binary division of the vesicle.

Yin (1997) described a second species of Tappania, T. tubata, that co-occurs with T. plana and has a broad tubelike extension but not trapezoidal neck-like extension, with a fimbriate distal margin and a few small processes on its extension surface. The Roper Tappania population displays the range of morphological characters originally ascribed to T. plana and T. tubata, occasionally on a single specimen. Therefore, we consider T. tubata to be a synonym of the senior species, Tappania plana. Prasad and Asher (2001) described a third species, Tappania gangaei, based on the rounded bulbous extension, rather than trapezoidal or tube-like. However, in the Roper population, specimens may bear both neck-like and rounded extension (interpreted as budding structures), therefore here too, we consider T. plana as the senior synonym.

Vesicles bearing neck-like expansions but no processes are reported as cf. Tappania? in the late Mesoproterozoic-early Neoproterozoic Mbuyi-Mayi Supergroup, RDC (Baludikay et al., 2016). However, the absence of processes on any of the six specimens observed so far and the younger age of these fossils leaves this occurrence ambiguous, even though Tappania populations elsewhere also include similar morphologies without processes. Indeed, so far, Tappania plana seems to be restricted to uppermost Paleoproterozoic to Mesoproterozoic rocks. Butterfield (2005a) described specimens from the midNeoproterozoic Wynniatt Formation, the Canadian arctic as Tappania, but these show a complex pattern of septation, peripheral branching and anastomosis not found in Mesoproterozoic populations and lack the neck-like expansions or the closed and rounded process terminations characteristic of older fossils. Therefore, the Neoproterozoic population might usefully be placed into a separate genus.

\section{Genus Tortunema Hermann, 1976}

Type species.-Tortunema wernadskii (Schepeleva, 1960) Butterfield et al., 1994.

\section{Tortunema sp.}

Figure 6.16

Description.-Fragmental remains of compressed cylindrical sheaths, $250-300 \mu \mathrm{m}$ long and $30 \mu \mathrm{m}$ wide $(\mathrm{N}=2)$, marked by thin, regularly spaced, transverse annulations that record cell boundaries of originally ensheathed trichomes. Spacing of

Figure 6. Photographs of Roper organic-walled microfossils: (1-15) Tappania plana: arrow in (1) showing furcating process, arrows in (2-4) showing septae in processes, (3) showing details from specimen in (2), arrow in (11) showing the area of locally grouped small processes shown in (12), arrow in (15) shows open neck-like expansion, suggesting excystment structure. (16) Tortunema sp. (17, 18) Trachytrichoides sp.: (18) showing details of cells morphology in filaments in (17). Scale bar in (1) is: $(\mathbf{1}, \mathbf{2}) 40 \mu \mathrm{m} ;(\mathbf{3}, \mathbf{1 1}) 10 \mu \mathrm{m} ;(\mathbf{4}, \mathbf{8}, \mathbf{1 4}) 20 \mu \mathrm{m} ;(\mathbf{5}, \mathbf{9}, \mathbf{1 6}, \mathbf{1 7}) 30 \mu \mathrm{m} ;(\mathbf{6}, \mathbf{1 0}, \mathbf{1 2}, \mathbf{1 5}, \mathbf{1 8}) 15 \mu \mathrm{m} ;(\mathbf{7}) 27 \mu \mathrm{m} ;(\mathbf{1 3}) 25 \mu \mathrm{m}$. Slide and England finder coordinates: (1) GG1 340.2 m .3 B X36/2, (2, 3) GG1 340.2 m .2 A J47/2, (4) GG1 340.2 m .3B T40/2, (5) GG1 340.2 m .2A E28/4, (6) U5 $151.3 \mathrm{~m} .2$ Q28/3, (7) GG1 326.2 m .2 V33/1, (8) U5 151.3 m .2 Y14/2, (9) GG1 340.2 m .3 H26/2, (10) GG1 326.2 m .3 F39/1, (11, 12) GG1 340.2 m .2 E17/1, (13) GG1 326.2 m .2 Y28/4, (14) GG1 340.2 m .3 O19/1, (15) U5 130.5 m .2 U9, (16) A82/3 379.1M G57/0, and (17) U6 240.2 m .2B J34/1. 
prominent annulations $6 \mu \mathrm{m}$, commonly with less-pronounced annulations between them.

Materials.-Two specimens.

Discussion.-Pseudoseptate filaments, widely distributed in Proterozoic platform and inner-shelf shales, are generally interpreted as the empty sheaths of cyanobacteria (e.g., Jankauskas, 1989; Butterfield et al., 1994). These sheaths are larger than the type species of the genus, T. wernadskii (Schepeleva) Butterfield. Because they are rare, we have little sense of their size frequency distribution, so only identify them as Tortunema sp.

Genus Trachytrichoides Hermann in Timofeev, Hermann, and Mikhailova, 1976

Type species.-Trachytrichoides ovalis Hermann in Timofeev et al., 1976.

Trachytrichoides sp.

Figure 6.17-6.18

Description.-Multicellular filaments with ovoid cells and thick intercellular septa, no external sheath, $157 \mu \mathrm{m}$ long and $5 \mu \mathrm{m}$ wide $(\mathrm{N}=3)$, with individual ellipsoidal cells $5 \mu \mathrm{m}$ wide $\mathrm{x}$ $6 \mu \mathrm{m}$ long.

Materials.-Three filaments observed in sample U6 $240.2 \mathrm{~m}$ of the Mainoru Formation.

Remarks.-A rare component of the Roper Group, differs from other filamentous taxa by the oval shape of the cells and absence of ellipsoidal fold between the cells (as in Arctacellularia), and from the type species $T$. ovalis by the smaller cell size than those of the holotype $(25-35 \mu \mathrm{m}$ wide and $30-60 \mu \mathrm{m}$ long).

Genus Valeria Jankauskas, 1982, emend. Nagovitsin, 2009

Type species.-Valeria lophostriata (Jankauskas, 1979b) Jankauskas, 1982.

Valeria lophostriata (Jankauskas, 1979b) Jakauskas, 1982 Figure 7.1-7.4

1979b Kildinella lophostriata Jankauskas, p. 153, fig. 1.131.15 .

1982 Valeria lophostriata; Jankauskas, p. 109, pl. 39, fig. 2.

1983 Kildinosphaera lophostriata; Vidal and Siedlecka, p. 59, fig. 6A-G.

1985 Kildinosphaera lophostriata; Vidal and Ford, p. 361, fig. 4C, E-F.

1989 Valeria lophostriata; Jankauskas et al., p. 86, pl. 16, figs. 1-5. [See for additional synonymy]

1994 Valeria lophostriata; Hofmann and Jackson, 1994, p. 24, pl. 17, figs. 14-15; pl. 19, fig. 4.

1997 Valeria lophostriata: Xiao et al., p. 201, fig. 3e.

1999 Valeria lophostriata; Samuelsson et al., p. 15, fig. 8E.

2001 Valeria lophostriata; Javaux et al., fig. 1D.

2004 Valeria lophostriata; Javaux et al., fig. 2F-I.
2009 Valeria lophostriata; Nagy et al., fig. 1A, B.

2009 Valeria lophostriata; Nagovitsin, p. 144, fig. 4E.

2009 ovoidal acritarch with striated ornamentation Peng et al., fig. 4.

2009 ovoidal acriatrch with striated ornamentation Lamb et al., fig. 4 A.

?2012 "dark walled megasphaeric coccoid with a subradial striation" Battison and Brasier, fig. 8B.

2015 Valeria lophostriata; Tang et al., p. 315, fig. 11.

in press Valeria lophostriata; Riedman and Porter, p. 10, fig. 4.1. in press Valeria lophostriata; Porter and Riedman, fig. 19.1-19.3.

(For additional synonymy see Jankauskas et al., 1989, and Hofmann and Jackson, 1994)

Holotype.-Number 16-62-4762/16, sp. 1, DH Kabakovo 62 drill core, depth 4762 to 4765 meters, Neoproterozoic Zigazino-Komarovo Formation, southern Urals (Jankauskas, 1979b, fig. 1.14).

Description.-Large vesicle, $104-160 \mu \mathrm{m}$ in minimum diameter, with lanceolate folds and a distinctive ornamentation of concentric ridges, giving the appearance of a "target" (Fig. 7.3, 7.4).

Occurrence.-This taxon is found worldwide (Hofmann, 1999) from the late Paleoproterozoic Era (Javaux et al., 2004; Lamb et al., 2009; Peng et al., 2009) to the Cryogenian (Nagy et al., 2009).

Materials.-Several specimens observed, mostly in samples U6 $305.1 \mathrm{~m}$, U6 $273.7 \mathrm{~m}$, and U6 $240.2 \mathrm{~m}$ from the Mainoru Formation.

Remarks.-SEM analyses show that the striations are $1-\mu \mathrm{m}$ ridges located on the inside of the vesicle wall (Javaux et al., 2004). Excystment by medial split gives rise to two half vesicles that commonly enroll onto themselves (Fig. 7.1, 7.2).

\section{Unnamed form A}

Figure 7.5-7.6

Description.-A large ovoidal or irregular and globular envelope including several contiguous compartments, each surrounded by an envelope and containing closely packed spheroidal cells. Two fragmented specimens are $350 \mu \mathrm{m}$ wide and 600-700 $\mu \mathrm{m}$ long, internal compartments surrounded by an inner envelope $39-85 \mu \mathrm{m}$ in diameter, containing poorly defined, closely packed cells. The external envelope is 8-13 $\mu \mathrm{m}$ thick.

Materials.-Two specimens in sample U6 $305.1 \mathrm{~m}$ from the Mainoru Formation.

Unnamed form B

Figure 7.7-7.8 


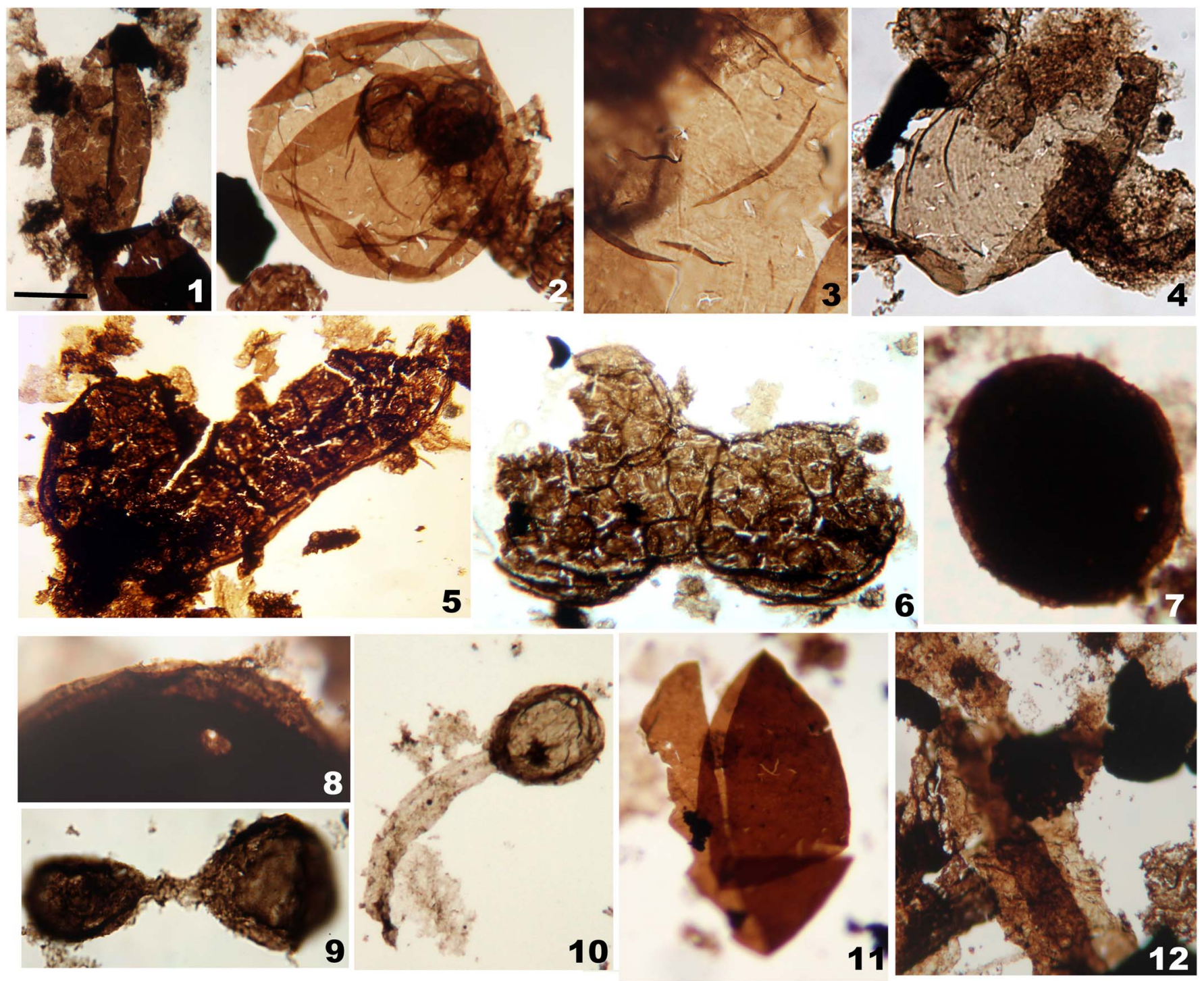

Figure 7. Photographs of Roper organic-walled microfossils: (1-4) Valeria lophostriata: (1) showing half enrolled vesicle following medial split, (2) showing start of medial split, $(\mathbf{3}, \mathbf{4})$ showing wall ornamentation by characteristic concentric striations. $(\mathbf{5}, \mathbf{6})$ Unnamed form A, large compartmentalized colonial forms. $(\mathbf{7}, \mathbf{8})$ Unnamed form B, opaque spheromorph, (8) showing details of folds at periphery. (9) Unnamed form C, spheromorphs connected by a filamentous expansion. (10) Unnamed form D, spheromorph with a filamentous expansion. (11) Unnamed form E, large smooth thick brittle spheromorph. (12) Unnamed form F, large filament in indented sheath. Scale bar in (1) is: (1) $100 \mu \mathrm{m},(\mathbf{2}, \mathbf{4 , 8}) 25 \mu \mathrm{m},(\mathbf{3}) 10 \mu \mathrm{m},(\mathbf{5}) 70 \mu \mathrm{m},(\mathbf{6}) 120 \mu \mathrm{m},(\mathbf{7}) 45 \mu \mathrm{m},(\mathbf{9}) 18 \mu \mathrm{m},(\mathbf{1 0}, \mathbf{1 5}) 30 \mu \mathrm{m}$, (11) $80 \mu \mathrm{m}$, and (12) $55 \mu \mathrm{m}$. Slide and England finder coordinates: (1) U6 $305.1 \mathrm{~m} .2 \mathrm{~A} \mathrm{S41}$, (2) U6 $230.8 \mathrm{~m} .2 \mathrm{~N} 27 / 2$, (4) U6 233.6 B45/0, (5) U6 305.1 m .2A O/N39, (6) U6 305.1 m B45/1, (7) GG1 340.2 m .3B U30, (9) U5 $125.1 \mathrm{~m} .2 \mathrm{M} 41 / 3$, (10) GG1 326.2 m .2 E20/1, (11) U6 240.2 m .2U27/2, (12) U5 $436.7 \mathrm{~m} .2 \mathrm{~S} 51$.

Description.-Black opaque vesicles, 141 and $215 \mu \mathrm{m}$ in diameter $(\mathrm{N}=2)$, with medial split and folds at periphery.

Materials.-Two specimens in sample GG1 $340.2 \mathrm{~m}$ from the Corcoran Formation.

Remarks.-These vesicles differ from Chuaria circularis by the translucent margin showing folds.

\section{Unnamed form $\mathrm{C}$}

Figure 7.9

Description.-Vesicles with smooth to chagrinate walls, 30 and $35 \mathrm{~m}$ in diameter $(\mathrm{N}=2)$, connected by a $14-\mu \mathrm{m}$-long filamentous expansion.
Materials.-Two vesicles in sample U5 $125.1 \mathrm{~m}$ from the Jalboi Member.

\section{Unnamed form D}

Figure 7.10

Description.-Vesicle $40 \mu \mathrm{m}$ in diameter, attached to a large $80 \mu \mathrm{m}$ filamentous expansion, but not communicating with the cell interior (thus distinct from Germinosphaera).

Materials.-One specimen in sample GG1 $326.2 \mathrm{~m}$ from the Corcoran Formation.

\section{Unnamed form $\mathrm{E}$}

Figure 7.11 
Description.-Large, smooth-walled, thick, brittle, brownorange wall fragment of a spheromorph, $310 \mu \mathrm{m}$ in diameter.

Materials.-One specimen in sample U6 $240.2 \mathrm{~m}$ from the Mainoru Formation.

\section{Unnamed form $\mathrm{F}$}

Figure 7.12

Description.-Large, 16 to $29 \mu \mathrm{m}$ wide filament in a $72 \mu \mathrm{m} \mathrm{x}$ $171 \mu \mathrm{m}$ smooth indented sheath.

Materials.-A single specimen in sample U5 $437 \mathrm{~m}$ from the Mainoru Formation (Showell Creek Member).

Remarks.-This large filamentous fossil differs from other sheathed filamentous taxa by the indentation of the sheath and absence of septae in the filament, although these characters could be taphonomic. Other taxa, such as Rugosoopsis, can reach large diameters, but have a distinct transverse fabric not observed here. Palaeolyngbya may also have a wide sheath, but is characterized by regular uniseriate array of well-preserved cells (Butterfield et al., 1994).

\section{Discussion}

Paleoecology: the distribution of Roper fossils in space.Abbott and Sweet (2000) interpreted Roper sequence stratigraphy in terms of four facies groups: (1) paralic to fluviatile redbeds characterized by heterolithic, iron-rich sandstones along with finer siliciclastics and oolitic ironstone, dessication cracks and paleosols; (2) tide-dominated shoreline sandstones dominated by trough cross-bedded quartz arenite; (3) shore-face to storm-dominated shelf deposits with alternating rippled and cross-bedded quartz arenites and laminated siltites and shales; and (4) basinal facies consisting of thinly laminated shales deposited below storm wave base. In a preliminary study, Javaux et al. (2001) suggested that Roper diversity peaked in coastal facies, and analysis of the entire sample suite confirms this view. Microfossils do not occur in tidal sandstones and ironstones, but are abundant in shaley intervals of shoreface and proximal shelf successions. Indeed, diversity is highest in shallow shelf environments characterized by interbedded shales and cross-bedded sandstones, with individual taxa peaking in abundance at different points along the shelf gradient (Fig. 8).

Eukaryotes and probable eukaryotes are least abundant and diverse in basinal shales throughout the Roper succession, the exception being Blastanosphaira kokkoda, which locally forms a monospecific assemblage in basinal shales, and rare Dictyosphaera. It has long been apparent empirically that quality of microfossil preservation varies inversely with total organic content (Butterfield et al., 1994). Therefore the limited presence of eukaryotes in basinal shales could reflect, in part, the high organic content of many basinal samples. That noted, even where basinal shales contain reasonably preserved microfossils, diversity is low. Bitumens occur throughout the Roper Group, in part the result of migration from source beds in the Velkerri Formation (Jackson and Raiswell, 1991; Dutkiewicz et al., 2003). Biomarker analysis of carbonaceous shales in the underlying McArthur Group suggests strong dominance of open water primary production by bacteria, including anoxygenic photosynthetic bacteria that inhabited anoxic waters within the photic zone (Brocks et al., 2005).

Biostratigraphy: the distribution of Roper fossils in time.Early work in Russia established a broad biostratigraphic framework for organic-walled microfossils in Proterozoic shales, with Satka favosa characterizing early Mesoproterozoic samples and Valeria lophostriata more common in Neoproterozoic successions (summaries in Jankauskas et al., 1989; Sergeev et al., 2010). More recent research shows that both of these morphospecies co-occur with Tappania plana and other Roper taxa in the Kamo Group, Siberia, and in correlative shales of the Debengda Formation (Nagovitsin, 2009; Stanevich et al., 2009; Nagovitsin et al., 2010). The fossiliferous shales are interspersed with stromatolitic carbonates and so represent shallow platform environments. Depositional age is constrained only broadly by shale dating techniques to be ca. 1000-1500 Myr. Another possible Mesoproterozoic index fossil includes Lineaforma from the Roper Group, the Kotuikan Formation of Siberia (Vorob'va et al., 2015), and Belt Supergroup of Montana, USA (Adam, 2014).

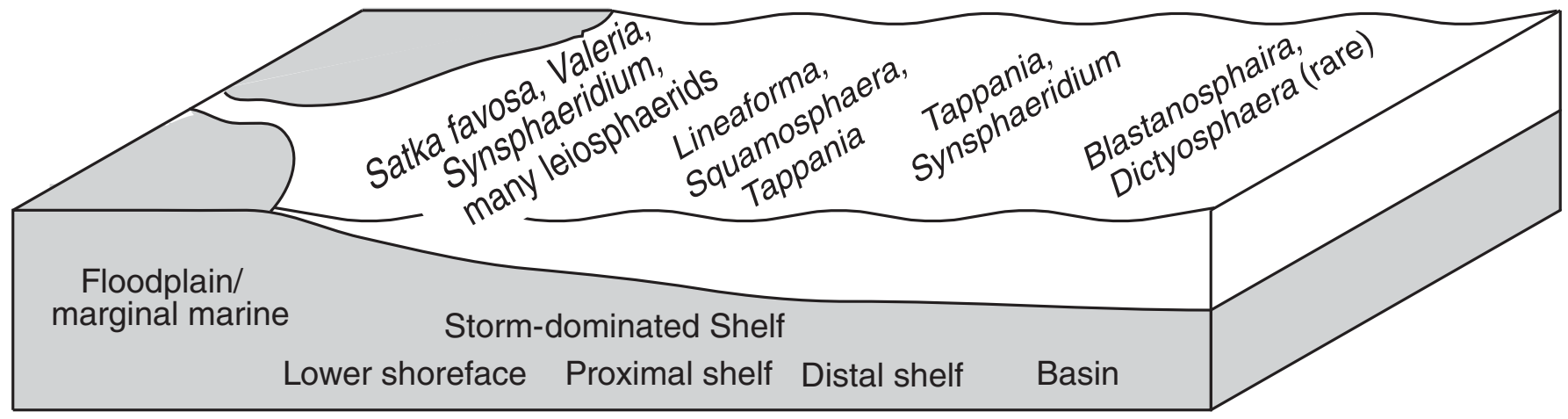

Decreasing abundance and diversity of microfos

Figure 8. Paleoecological distribution of selected microfossils in the Roper Group. 
Tappania plana occurs as well in the Ruyang Group, China (Xiao et al., 1997; Yin, 1997; Yin et al., 2005); the Sarda Formation of the Bahraich Group, Ganga Basin (Prasad and Asher, 2001) and possibly correlative beds of the Kheinjua Group,Vindhyan Basin (Prasad et al., 2005) in northern India; and in the Lower Belt Group, Montana (Adam, 2014; Adam et al., 2016). Detrital zircons indicate that Ruyang deposition began no earlier than $1700 \mathrm{Ma}$ (Hu et al., 2014), and xenotime $\mathrm{Pb}-\mathrm{Pb}$ ages of about $1400 \mathrm{Ma}$ for the overlying Luoyu Group constrain deposition from above (Lan et al., 2014). A U-Pb zircon date from an ash bed within the Luoyu Group potentially constrains Ruyang deposition to be older than $1611 \pm 8 \mathrm{Ma}$, but the abundance of detrital grains in the dated bed and the wide range of ages for individual zircons (Su et al., 2012) suggest that the published date may provide only a maximum age constraint on Luoyu deposition (Lan et al., 2014). Belt microfossils, which share many taxa in common with the Roper Group (Horodyski, 1980, 1993; Adam, 2014; Adam et al., 2016), are similarly constrained by a $1576 \pm 13$ Ma basement, $1460-1470$ Ma sills that intrude into the fossiliferous stratigraphy and a U-Pb zircon date of $1454 \pm 9 \mathrm{Ma}$ for bentonite in the overlying Helena Formation (Lydon, 2007). U-Pb zircon dating of ash beds just below the Vindhyan succession containing unambiguous Tappania indicates that these fossils are $\leq 1631 \pm 1$ Ma (Ray et al., 2002). Thus, all known occurrences of $T$. plana fall within the latest Paleoproterozoic or Mesoproterozoic Era, with the Roper and Belt populations being the most tightly constrained by radiometric ages. The absence in Roper assemblages of distinctive taxa (e.g., the distinctive acanthomorphic taxon Shuiyousphaeridium macroreticulatum or the ornamented forms Miroedichia sp. and Lophosphaeridium sp.) that cooccur with Tappania elsewhere could reflect differences in either age or environment (e.g., Nagovitsin et al., 2010).

More broadly, the moderately diverse protist compressions of the Roper Group are intermediate in nature between the simple leiosphere-dominated assemblages found in most late Paleoproterozoic shales (e.g., Lamb et al., 2009; Peng et al., 2009) and the slightly more diverse (and taxonomically distinctive) assemblages reported from late Mesoproterozoic shales (e.g., Hermann, 1990; Samuelsson et al., 1999). Recently, Vorob'eva et al. (2015) reported a relatively diverse assemblage of microfossils in the $\sim 1.5 \mathrm{Ga}$ Kotuikan Formation of Siberia. The assemblage includes 12-14 spheroidal and filamentous forms plausibly interpreted as eukaryotes, but no acanthomorphs. Notably, the Kotuikan assemblage contains the distinctively striated filament Lineaforma elongata, which is also found in the Roper Group. Sergeev et al. (2016) also reported well-preserved microfossils in shales of the 1.4-1.45 Ga Kaltasy Formation, East European Platform, Russia. This assemblage includes a number of probable eukaryotic taxa, but also lacks conspicuously ornamented spheromorphic populations, which in this case possibly reflects the unusual (for Mesoproterozoic successions) combination of basinal deposition and oxic bottom waters. In general, then, the summed occurrences suggest that while many of the organic-walled microfossils in the Roper and other assemblages have long stratigraphic ranges, some can be used to identify uppermost Paleoproterozoic and Mesoproterozoic sedimentary successions and may, in time, permit the broad subdivision of Mesoproterozoic time.
The phylogenetic and functional interpretation of Roper fossils.-Because Roper fossils are both unusually well preserved and differentially well constrained by age and environment, they prompt questions of phylogenetic affiliation. In particular, can individual populations be identified with confidence as eukaryotes and, if so, can they further be assigned to extant eukaryotic clades?

In principle, Roper populations could include the polysaccharide sheaths and envelopes of cyanobacteria or other bacteria, the walls of metabolically active eukaryotic cells, and eukaryotic resting or reproductive cysts. Cyst walls are commonly reinforced with compounds that improve preservation potential, for example, sporopollenin in plant spores, dinosporin in some dinoflagellates, and algaenan in a few green algae and eustigmatophytes (de Leeuw et al., 2006; Kodner et al., 2009; Scholz et al., 2014). Known and assumed protistan cysts predominate in Phanerozoic marine shales, and this has understandably influenced the interpretation of older microfossils. We must recognize, however, that prospects for the preservation of vegetative walls would have been enhanced in the low-oxygen, bioturbation-free muds found widely in earlier seaways, as illustrated by the preservation of simple multicellular and coenocytic remains in Neoproterozoic shales (Butterfield et al., 1994; Butterfield, 2009) and carbonaceous seaweeds in Ediacaran and Paleozoic successions (e.g., Xiao et al., 2002; LoDuca et al., 2003; Kenrick and Vinther, 2006; Yuan et al., 2011).

Bacterial microfossils do occur in the Roper assemblage, especially Siphonophycus spp., which is found as minor components of Roper assemblages. Sheath-forming filaments occur in a number of bacterial clades, but given their relatively large size and occurrence in oxic waters within the shallow reaches of the photic zone, Siphonophycus populations are most readily interpreted as cyanobacteria comparable to modern Lyngbya, Plectonema, and Phormidium (Rippka et al., 1979). The Roper assemblage also includes rare trichomes and pseudoseptate filaments that may record cyanobacteria or other bacteria. Such an interpretation is fully in accord both with microfossil assemblages preserved in Proterozoic cherts and molecular clocks that indicate major cyanobacterial diversification before the time of Roper deposition (Tomitani et al., 2006, and references cited therein).

Cyanobacteria may also occur among spheromorphic forms. Horodyski (1993), for example, interpreted Satka squamifera as possible envelopes of colonial entophysalid cyanobacteria, a view formalized by the reassignment of this and other probable synonyms of Satka colonialica to Squamosphaera (Tang et al., 2015; Porter and Riedman, in press). Simple leiosphaerid compressions could also include the envelopes of colonial coccoidal cyanobacteria, some of which can have both a large diameter and medial splits similar to those commonly interpreted as excystment structures in microfossils (Waterbury and Stanier, 1978). TEM may be necessary to ascertain the affinities of leiospherids, especially those with very thin walls. In the limited number of Roper specimens examined to date, preserved complex multilayered wall ultrastructure suggests eukaryotic rather than cyanobacterial affinities (Javaux et al., 2004; see systematic paleontology section). 
While comparisons to cyanobacteria are based principally on morphological similarities, constrained by paleoenvironmental setting (e.g., Knoll and Golubic, 1992), taphonomic experiments underscore the preservation potential of cyanobacterial sheaths and envelopes (e.g., Bartley, 1996). Recent microanalyses of modern and subfossil mats in Antarctic lakes provide strong evidence for the preservation of cyanobacterial morphologies and chemistries, including sheaths and the sheath pigment scytonemin (Lepot et al., 2014).

If eukaryotic, Roper microfossils must be viewed as the remains of cell walls, which places both functional and phylogenetic constraints on interpretation. Cell walls are best known from algae, especially the cellulosic cell walls of green, red, brown, dinoflagellate, and some golden-brown algae (Graham and Wilcox, 2000). Walls occur, as well, in osmotrophic eukaryotes, including the chitinous walls of fungi and the cellulosic walls of oomycetes (Melida et al., 2013). Moreover, a wall can form during a specific life cycle stage, even in organisms not otherwise characterized by cell wall synthesis (e.g., the cellulosic macrocyst walls of dictyostelid amoebozoans) (Saga and Yanagisawa, 1982; Blanton et al., 2000) and chemically uncharacterized walls synthesized by coccoidal cells in chlorarachniophyte rhizarians (Ishida and Hara, 1994).

Walled resting or reproductive cysts occur widely within the Eukarya, not only in algae, but also in heterotrophic clades. Ciliates, for example, make cyst walls that can be smooth or conspicuously ornamented (Beers, 1948, 1966; Foissner et al., 2007; Verni and Rosati, 2011), and so do many animals (e.g., Blades-Eckelbarger and Marcus, 1992). In many eukaryotes, cyst formation (commonly but not always associated with sexual fusion) is induced by conditions that inhibit growth, including desiccation, nutrient deprivation, and anoxia, and so one might expect a resting stage to occur in the life cycles of eukaryotes in oceans with anoxic water masses beneath a thin oxic mixed layer (Johnston et al., 2012). The broad phylogenetic distribution of cellulose and other wall compounds suggests that the ability to synthesize a protective wall evolved early in the Eukarya, perhaps before the earliest divergences of crown group taxa.

Tappania plana has been interpreted as a metabolically active microorganism on the basis of its irregularly placed, occasionally branching processes that extend outward from the main vesicle (Xiao et al., 1997; Javaux et al., 2003, 2004). Bulbous extensions on the same individuals may record vegetative reproduction. Cell walls that completely encompass individuals are common in photosynthetic and osmotrophic eukaryotes, but the cylindrical extensions provide a functional argument in favor of osmotrophy. These structures would increase the surface area for absorption and enable cells to probe nutrient-rich habitat patches, but would do little to enhance primary production. Butterfield (2005a), in fact, interpreted Tappania as a possible fungus, based on a population from Neoproterozoic shales of the Shaler Group, the Canadian Arctic (but see Butterfield, 2015). As noted in the systematic paleontology section, Shaler fossils differ in many ways from Roper and other Mesoproterozoic Tappania, but the functional argument holds. In eukaryote evolution, phagotrophy is the ancestral state (evolved at least at the time of LECA, Knoll and
Lahr, 2016), while phototrophy required the evolution of chloroplast by endosymbiosis of a cyanobacteria, and thus is derived and evolved not later than $1.1 \mathrm{Ga}$-the age of Bangiomorpha. Today, many marine protists are mixotrophs (able to use both phagotrophy and phototrophy; Mitra et al., 2016).

The ability to absorb dissolved organic molecules (osmotrophy) is ubiquitous among protists (Mitra et al., 2016), but only a few clades, chiefly fungi and oomycetes, employ osmotrophy as the primary or sole means of obtaining food, having lost phagotrophy (Richards and Talbot, 2013). Recently, Knoll and Lahr (2016) investigated the phylogenetic distribution of major feeding modes within the Eukarya. While bacterivory is basal within the domain, other feeding modes evolved early, helping to explain the later Mesoproterozoic diversification of crown groups. Molecular clock estimates for the initial divergence of crown group fungi generally postdate Roper time (e.g., 800 Ma, Berney and Pawlowski, 2006; 730 820 Ma, Lücking et al., 2009; 1050 Ma, Parfey et al., 2011; 812 Ma, Floudas et al., 2012). Crown group Stramenopiles may also have late Mesoproterozoic or Neoproterozoic origins (e.g., Parfrey et al., 2011). For this reason, it is possible that early Mesoproterozoic Tappania fossils record stem group protists functionally, but not necessarily phylogenetically comparable to extant osmotrophic heterotrophs. In any event, the complex morphology of Tappania provides direct evidence for cell organization by a dynamic cytoskeleton and membrane system, which is a fundamental feature of eukaryotic biology (Javaux et al., 2001; Knoll et al., 2006).

Other Roper fossils find reasonable interpretation as cyst walls, for example, Valeria lophostriata, with its distinctive ornamentation of parallel ridges and opening by medial split (Javaux et al., 2003, 2004). Accepting V. lophostriata as a resting or reproductive cyst relaxes any constraint on its metabolism or placement within a specific subgroup of the eukaryotic domain (as noted above, cysts occur in many eukaryotic taxa that lack walls on metabolically active cells). Similarly, the ornamented spheromorphs Dictyosphaera delicata, with its reticulated wall, and Satka favosa, with its wall made of polygonal plates and (rare) opening by medial split, are best interpreted as eukaryotic cysts. Blastanosphaira kokkoda has a finely chagrinate wall, and intensive budding, both of which are evidence for vegetative reproduction.

Spheromorphic microfossils in Paleo- and Mesoproterozoic rocks have sometimes been interpreted as green algae, requiring an early origin of photosynthesis in the domain (Moczydłowska et al., 2011). Chlorophyte algae are sometimes recognized on the basis of a distinctive trilaminar structure (TLS) observed in TEM images of cell walls (Allard and Templier, 2000), and TLS has been documented in microfossils as old as Cambrian (Talyzina and Moczydłowska, 2000). TLS covaries phylogenetically with the biosynthetic capacity to make long-chain aliphatic molecules called algaenans (Allard and Templier, 2000), and a phylogenetic survey of this capacity suggests that it may be limited to two (now) non-marine clades within the Trebouxiophyceae and Chlorophyceae (Kodner et al., 2009), neither of which is likely to have diverged much earlier than the Ediacaran or Cambrian periods. In the Roper Group's taxa studied with 


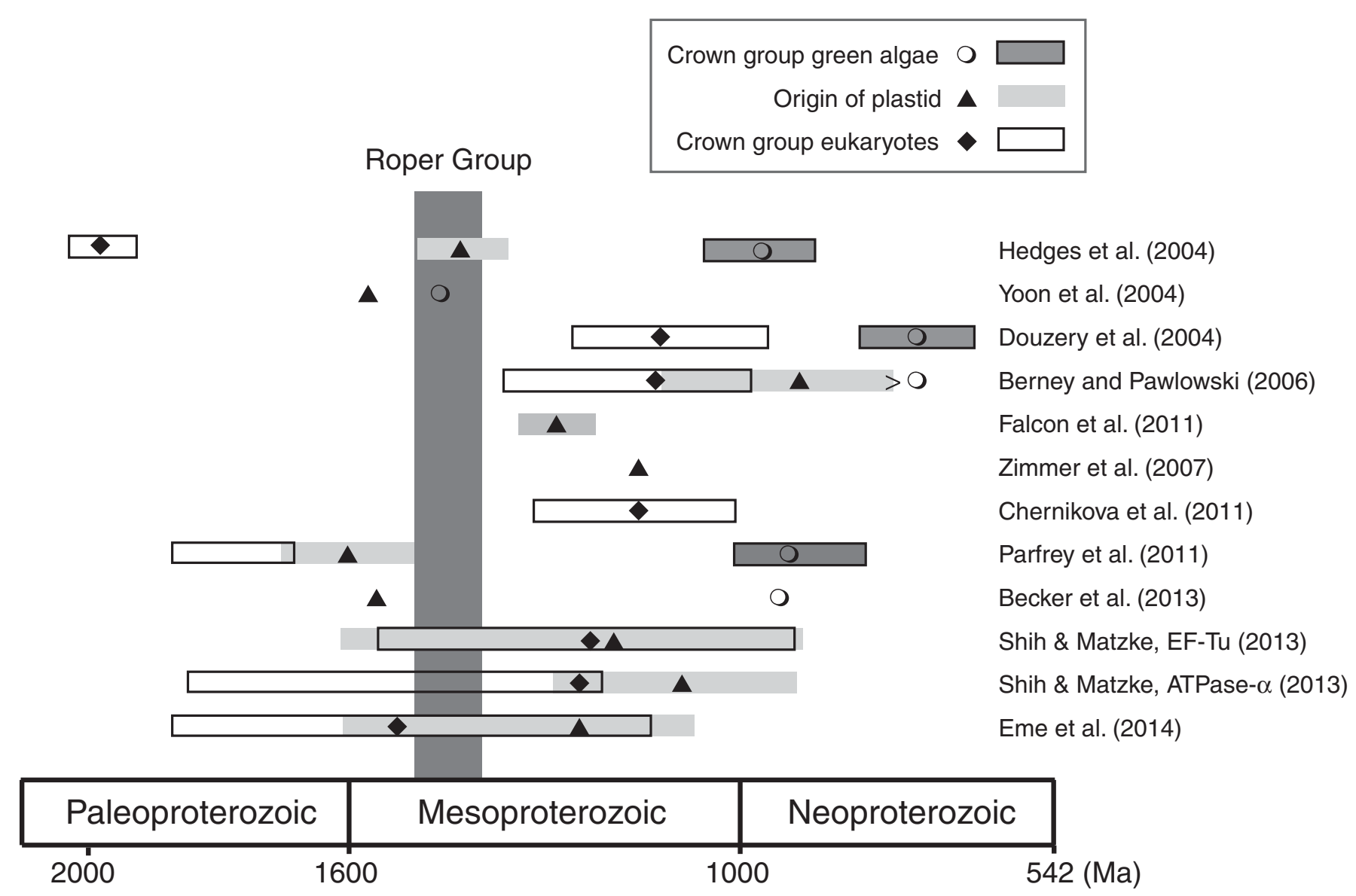

Figure 9. Comparison of Roper age with molecular clock estimates for the divergences of crown group green algae, photosynthetic eukaryotes, and crown group eukaryotes. Circle, diamond and triangles are the mean ages for the origin of crown group algae, plastid, crown group eukaryotes, respectively, and the dark gray, medium gray and white rectangles represent the errors on estimates, respectively.

TEM, the occurrence of TLS has not been observed to date and we have no indication for photosynthetic eukaryotic crown group taxa (Javaux et al., 2004).

Alternatively, prasinophyte algae, a paraphyletic group at the base of the green algal tree, can form thick-walled phycomata, which are found widely in Paleozoic shales (Colbath and Grenfell, 1995). Some phycomata have a diagnostic ultrastructure (Talyzina and Moczydłowska, 2000), but this has not been observed in Roper or other microfossils of comparable age. Thus, the argument that Roper and other early microfossil assemblages contain green algae must rely on broad comparisons of simple morphologies and the debatable assumption that preserved eukaryotic microfossils are likely to be algal.

Molecular estimates for the origin of crown group green algae vary widely (Fig. 10), but generally suggest late Mesoproterozoic or younger diversification (e.g., $1100 \mathrm{Ma}$, Heckman et al., 2001; $1200 \mathrm{Ma}$, Yoon et al., 2004; 1000$900 \mathrm{Ma}$, Parfrey et al., 2011; $936 \mathrm{Ma}$, Becker, 2013; and even $\sim 700 \mathrm{Ma}$, Berney and Pawlowski, 2006). The $\sim 800 \mathrm{Ma}$ Cladophora-like fossil Proterocladus casts doubt on the youngest molecular clock estimates, and the early diverging red alga Bangiomorpha from 1100-1200 Ma cherts in the Canadian Arctic (Butterfield, 2000) further constrains the age of total (but not crown) group green algae. Nonetheless, if even the oldest of current molecular clock estimates is broadly correct, it is unlikely that Roper microfossils can be interpreted in terms of specific extant clades within the green algae.

If Roper leiosphaerids cannot be assigned to crown group green algal clades, what are the possibilities for phylogenetic placement? Not surprisingly, age estimates for the last eukaryotic common ancestor (LECA) of all extant eukaryotes vary among treatments, but those not rejected on the basis of Bangiomorpha's age and interpretation suggest a late Paleoproterozoic or early Mesoproterozoic time of origin for the eukaryotic crown group (Fig. 9). Accepting this, Roper fossils could include the vegetative walls or resting cysts of stem-group green algae, stem-group taxa of the more inclusive Archaeplastida (green algae/embryophytes, red algae and glaucocystophytes, united by the presence of a chloroplast derived via primary endosymbiosis with a cyanobacterium), stem-group or morphologically unrecognizable crown-group members of other non-photosynthetic eukaryotic clades, or stem-group eukaryotes (before LECA). In the absence of additional data, we find it impossible to choose among these possibilities. Note, however, that it would not be unusual to have a biota dominated by stem-group members of a clade. For example, most arthropod diversity in early and mid-Cambrian oceans belonged to stem group members of the phylum, and the same is true of 


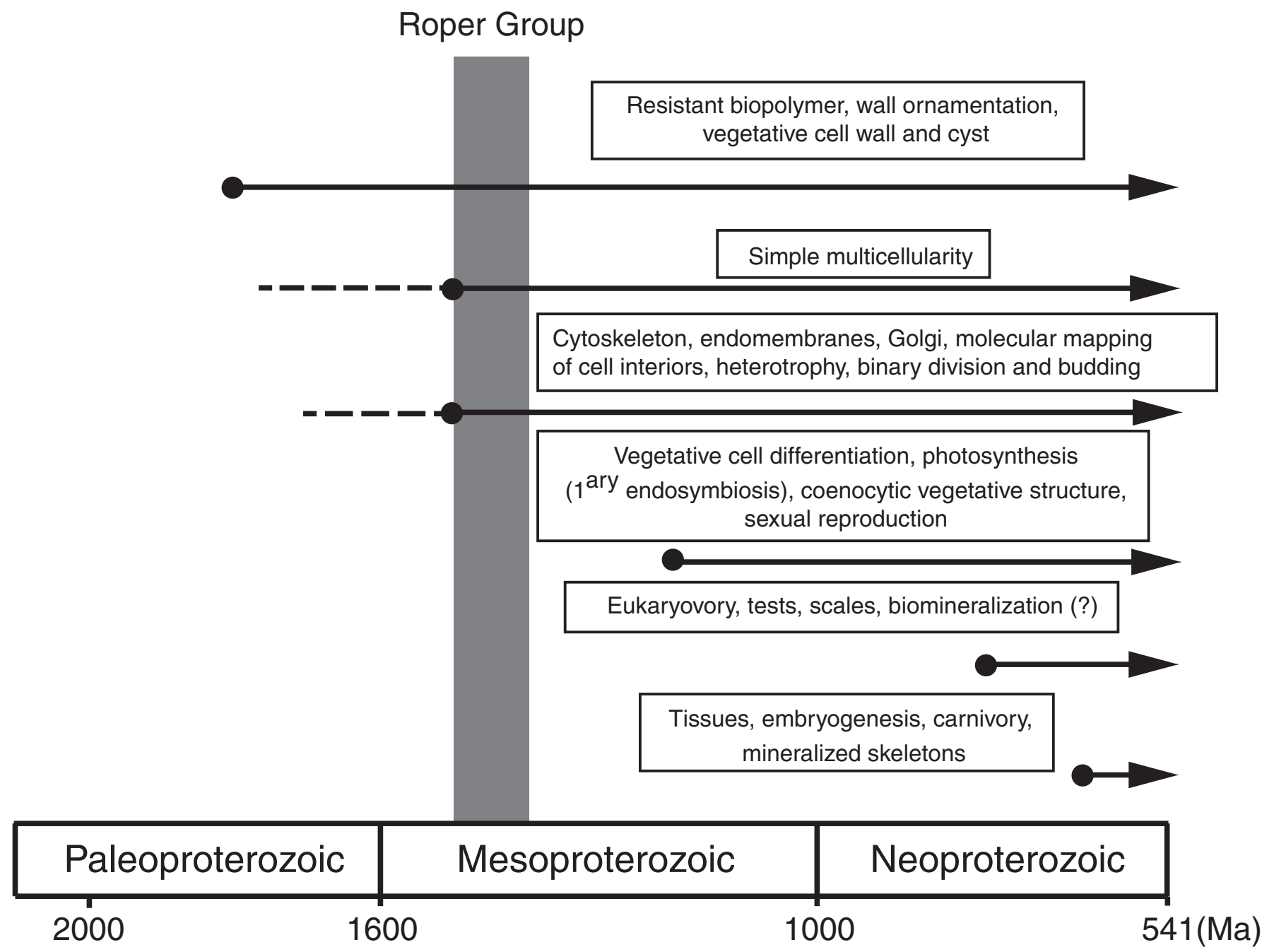

Figure 10. Biological innovations in early eukaryotes inferred from preserved microfossils (modified from Javaux, 2011).

Cambrian echinoderms, Carboniferous seed plants, and many other clades. Stem-group taxa are common in the deep fossil record.

Finally, there are the large, striated tubes of Lineaforma elongata, which commonly are fragmental but locally abundant in Roper samples. The size and complexity of these tubes favor a eukaryotic interpretation, but more specific attribution is impossible.

In general, then, eukaryotic remains are prominent, even dominant components of the Roper assemblage, but all are simple and, at lower taxonomic levels, problematic. Consistent with molecular clock inferences, Roper eukaryotes may include stem-group taxa; early, morphologically unattributable crowngroup species; or both. Missing from the Roper biota are highly ornamented cysts of the type found commonly in later Neoproterozoic and, especially, Phanerozoic shales. Cyst ornamentation can serve a number of purposes (see, for example, Cohen et al., 2009), one of which is defense against predation (e.g., Peterson and Butterfield, 2005). The last common ancestor of extant eukaryotes was probably a heterotroph capable of phagocytosing bacteria and other small particles; eukaryotes that eat other eukaryotic cells, however, are derived (Knoll and Lahr, 2016). The limited ornamentation of Roper microfossils is consistent with the hypothesis that predation on protists was low prior to the Neoproterozoic Era, because of the relatively late radiation of eukaryovorous protists (Knoll, 2014) and animals (Butterfield, 2015).

Taxonomy aside, the Roper assemblage documents biological innovations in early eukaryotes (Fig. 10; see also Javaux, 2006, 2011; Knoll et al., 2006). Reproductive modes in Roper populations include simple binary division and budding (e.g., Tappania, Blastanosphaira). We have no direct evidence for sex in Roper populations, but this reflects absence of evidence and not necessarily evidence of absence. Sex was present in the last common ancestor of extant eukaryotes, so any paleontological inference must rest on currently uncertain systematic interpretations of Roper fossils as stem- or crown-group eukaryotes. Whether associated with sexual fusion or not, Roper protists formed resting cysts, with excystment by medial split (Valeria, Satka favosa) and possibly by the opening of neck-like expansions (Tappania). Simple multicellularity is observed both in eukaryotes (septa in Tappania processes) and in prokaryotes (colonies of diverse types and filaments). The wall ornamentation of several taxa, especially Tappania's 
heteromorphic processes and the plates of Satka favosa and Dictyosphaera delicata, implies the presence of a eukaryotic cytoskeleton. The tessellation of organic plates to make up the wall of these acritarchs further suggests the presence of an internal membrane system (including endoplasmic reticulum, or ER) and Golgi apparatus. The Golgi apparatus (or remnants of, in parasites) and the ER are essential for intracellular transport, occur in all extant eukaryotes, and are associated with the nuclear envelope (Jékely, 2006), although the relative timing of their appearance is unknown and the origin of the nucleus itself is far from constrained (see review in Lopez-Garcia and Moreira, 2015).

\section{Conclusions}

Roper microfossils contribute to an increasingly refined picture of life in Mesoproterozoic oceans, complementing the window opened by microfossils preserved in silicified carbonates. Chert assemblages largely illuminate peritidal environments dominated by diverse cyanobacteria and contain few recognizable eukaryotes (Muir, 1976, 1979; Oehler, 1978; Horodyski and Donaldson, 1980, 1983; Zhang, 1981; Golubic et al., 1995; Sergeev et al., 1995).

Stromatolites further indicate that microbial mat communities covered extensive portions of the Mesoproterozoic seafloor, extending from supratidal environments to the base of the photic zone (Bertrand-Sarfati and Walter, 1981; Walter et al., 1988). Cyanobacteria are generally accepted as the principal architects of Mesoproterozoic stromatolites, but whether eukaryotes participated in mat communities is difficult to know, given that few stromatolites contain well-preserved microfossils. Variation in macrostructure may well tell us mostly about the range of physical and chemical environments in which stromatolites accreted (e.g., Grotzinger and Knoll, 1999; Bosak et al., 2013), but microstructure, or petrofabric, can preserve clues to microbial community diversity (Knoll et al., 2013). Eukaryotes could be recorded by macroscopic chain-ofbeads impressions called Horodyskia (Grey and Williams, 1990; Fedonkin and Yochelson, 2002; review in Dong et al., 2008) and the Mesoproterozoic specimens of coiled centimeterscale septate compressions named Grypania (Walter et al., 1990), both exposed on siliciclastic bedding planes. The phylogenetic and functional nature of these organisms remains obscure.

Microfossils suggest that eukaryotic organisms were most common in the water column and non-mat benthos of welloxygenated, shallow-shelf environments. Because the last common ancestor of extant eukaryotes was a phagocytosing heterotroph that consumed bacteria and other small particles, Roper eukaryotes certainly would have played a role in completing the marine carbon cycle. This may have been true in anoxic as well as oxic environments, because many eukaryotes retain the capacity for anaerobic metabolism (Müller et al., 2012). Osmotrophic uptake of organic molecules must also have occurred, and appears to have the primary form of carbon acquisition in Tappania plana. As discussed above, phagotrophic protists were present in Mesoproterozoic oceans, but these may not have included protists able to eat other large eukaryotic cells.
Whether eukaryotes played an important role as primary producers is less clear. As noted above, microfossil morphologies are agnostic with respect to this metabolism, and limited organic geochemical data suggest that bacteria were the principal primary producers in Mesoproterozoic oceans (Brocks et al., 2005). Primary production by eukaryotes might well have been limited by fixed nitrogen availability (Anbar and Knoll, 2002; Reinhard et al., 2013), especially in oxic waters above sulfidic water masses (Boyle et al., 2013). The spatial distribution of presumed eukaryotes in the Roper Basin is consistent with isotopic inferences about Mesoproterozoic nitrogen cycling (Stüeken, 2013). Upward mixing of anoxic and sometimes sulfidic waters would also have constituted a persistent challenge for eukaryotes in the photic zone (Johnston et al., 2009, 2010; Guilbaud et al., 2015).

In short, Mesoproterozoic oceans supported diverse microbial communities that included early eukaryotes, some of them preserved in Roper shales. The diversity and ecological importance of these early protists, however, were much lower than in later Neoproterozoic and Phanerozoic ecosystems, which is a function, at least in part, of ecological constraints involving food web complexity and physical constraints imposed by marine redox profiles.

\section{Acknowledgments}

We thank M. Walter and the core facility staffs at the Northern Territory Geological Survey in Darwin and the Australian Geological Survey Organization in Canberra for making it possible to sample Roper cores. We also thank Z. Adam, V.N. Sergeev, L.A. Riedman, and S. Porter for discussion and access to unpublished materials, and reviewers for helpful criticisms of an earlier draft. E.J acknowledges support from European Research Council Stg ELITE FP7/308074, Belspo IAP Planet Topers, and the Francqui Foundation research professorship. AHK acknowledges support from NASA Exobiology Grant NAG5-3645 and the NASA Astrobiology Institute.

\section{References}

Abbott, S.T., and Sweet, I.P., 2000, Tectonic control on third-order sequences in a siliciclastic ramp-style basin: an example from the Roper Superbasin (Mesoproterozoic), northern Australia: Australian Journal of Earth Sciences, v. 47, p. 637-657.

Adam, Z.R., 2014, Microfossil Paleontology and Biostratigraphy of the Early Mesoproterozoic Belt Supergroup, Montana [Ph.D. dissertation]: Bozeman, Montana State University, 192 p.

Adam, Z.R, Skidmore, M.L., and Mogk, D.W., 2016, Paleoenvironmental implications of an expanded microfossil assemblage from the Chamberlain Formation, Belt Supergroup, Montana: The Geological Society of America Special Paper, v. 522, 20 p.

Agic, H., Moczydłowska, M., and Yin, L.-M., 2015, Affinity, life cycle, and intracellular complexity of organic-walled microfossils from the Mesoproterozoic of Shanxi, China: Journal of Paleontology, v. 89, p. $28-50$.

Allard, B., and Templier, J., 2000, Comparison of neutral lipid profile of various trilaminar outer cell wall (TLS)-containing microalgae with emphasis on algaenan occurrence: Phytochemistry, v. 54, p. 369-380.

Anbar, A.D., and Knoll, A.H., 2002, Proterozoic ocean chemistry and evolution: a bioinorganic bridge?: Science, v. 297, p. 1137-1142.

Angert, E.R., 2005, Alternative to division in Bacteria: Nature Reviews Microbiology, v. 3, p. 214-224.

Arnold, G.L., Anbar, A.D., Barling, J., and Lyons, T.W., 2004, Molybdenum isotope evidence for widespread anoxia in mid-Proterozoic oceans: Science, v. 304, p. 87-90. 
Baludikay, B.K., Storme, J.-Y., François, C., Baudet, D., and Javaux, E.J., 2016, A diverse and exquisitely preserved organic-walled microfossil assemblage from the Meso-Neoproterozoic Mbuji-Mayi Supergroup (Democratic Republic of Congo) and implications for Proterozoic biostratigraphy: Precambrian Research, v. 281, p. 166-184.

Bartley, J., 1996, Actualistic taphonomy of cyanobacteria: implications for the Precambrian fossil record: Palaios, v. 11, p. 571-586.

Battison, L., and Brasier, M.D., 2012, Remarkably preserved prokaryote and eukaryote microfossils within $1 \mathrm{Ga}$-old lake phosphates of the Torridon Group, NW Scotland: Precambrian Research, v. 196-197, p. 204-217.

Becker, B., 2013, Snow ball earth and the split of Streptophyta and Chlorophyta: Trends in Plant Sciences, v. 18, p. 180-183.

Beers, C.D., 1948, Excystment in the ciliate Bursaria truncatella: Biological Bulletin, v. 94, p. 86-98.

Beers, C.D., 1966, The excystment process in the ciliate Nassula ornata Ehrbg.: Journal of Protozoology, v. 13, p. 79-83.

Beghin, J., Storme, J.-Y., Blanpied, C., Gueneli, J., Brocks, J., Poulton, S., and Javaux, E.J., in review, Microfossils from the late Mesoproterozoic $(1.1 \mathrm{Ga})$ Atar/El Mreïti Group, Taoudeni Basin, Mauritania, northwestern Africa: Precambrian Research.

Berney, C., and Pawlowski, J., 2006, A molecular time-scale for eukaryote evolution recalibrated with the continuous microfossil record: Proceedings of the Royal Society, London, v. 273B, p. 1867-1872.

Bertrand-Sarfati, J., and Walter, M.R., 1981, Stromatolite biostratigraphy: Precambrian Research, v. 15 , p. 353-371.

Betts, P.G., and Gilles, D., 2006, The 1800-1100 Ma tectonic evolution of Australia: Precambrian Research, v. 144, p. 92-125.

Blades-Eckelbarger, P.I., and Marcus, N.H., 1992, The origin of cortical vesicles and their role in egg envelope formation in the spiny eggs of a calanoid copepod, Centropages velificatus: Biological Bulletin, v. 182, p. 41-53.

Blanton, R.L., Fuller, D., Iranfar, N., Grimson, M.J., and Loomis, W.F., 2000, The cellulose synthase gene of Dictyostelium: Proceedings of the National Academy of Sciences, USA, v. 97, p. 2391-2396.

Bosak, T., Knoll, A.H., and Petroff, A.P., 2013, The meaning of stromatolites: Annual Review of Earth and Planetary Sciences, v. 41, p. 21-44.

Boyle, R.A., Clark, J.R., Poulton, S.W., Shields-Zhou, G., Canfield, D.E., and Lenton, T.M., 2013, Nitrogen cycle feedbacks as a control on euxinia in the mid-Proterozoic ocean: Nature Communications, Article 4:1533, doi 10.1038/ncomms 2511 .

Brocks, J.J., Love, G.D., Summons, R.E., Knoll, A.H., Logan, G.A., and Bowden, S., 2005, Biomarker evidence for green and purple sulfur bacteria in an intensely stratified Paleoproterozoic ocean: Nature, v. 437 p. $866-870$.

Butterfield, N.J., 2000, Bangiomorpha pubescens n. gen., n. sp.: Implications for the evolution of sex, multicellularity, and the Mesoproterozoic/Neoproterozoic radiation of eukaryotes: Paleobiology, v. 26, p. 386-404.

Butterfield, N.J., 2004, A vaucherian alga from the Middle Neoproterozoic of Spitsbergen: implications for the evolution of Proterozoic eukaryotes and the Cambrian explosion: Paleobiology, v. 30, p. 231-252.

Butterfield, N.J., 2005a, Probable Proterozoic fungi: Paleobiology, v. 31, p. $165-182$.

Butterfield, N.J., 2005b, Reconstructing a complex Early Neoproterozoic eukaryote, Wynniatt Formation, Arctic Canada: Lethaia, v. 38, p. 155-169.

Butterfield, N.J., 2009, Modes of pre-Ediacaran multicellularity: Precambrian Research, v. 173, p. 201-211.

Butterfield, N.J., 2015, Early evolution of the Eukaryota: Palaeontology, v. 58, p. 5-17.

Butterfield, N.J., Knoll, A.H., and Swett, K., 1994, Paleobiology of the Neoproterozoic Svanbergfjellet Formation, Spitsbergen: Fossils and Strata, v. 34, p. $1-84$.

Chernikova, D., Motamedi, S., Csueroes, M., Koonin, E.V., and Rogozin, I.B., 2011, A late origin of the extant eukaryotic diversity: divergence time estimates using rare genomic changes: Biology Direct, v. 6, Article Number: 26, doi: 10.1186/1745-6150-6-26.

Cohen, P.A., and Knoll, A.H., 2012, Neoproterozoic scale microfossils from the Fifteen Mile Group, Yukon Territory: Journal of Paleontology, v. 86, p. $775-800$

Cohen, P.A., Kodner, R., and Knoll, A.H., 2009, Large spinose acritarchs in Ediacaran rocks as animal resting cysts: Proceedings of the National Academy of Sciences, USA, v. 106, p. 6519-6524.

Colbath, G.K., and Grenfell, H.R., 1995, Review of biological affinities of Paleozoic acid-resistant, organic-walled eukaryotic algal microfossils (including "acritarchs"): Review of Palaeobotany and Palynology, v. 86, p. $287-314$

Cotter, K., 1997, Neoproterozoic microfossils from the Officer Basin, Western Australia: Alcheringa, v. 21, p. 247-270, doi: 10.1080/031155197 08619166.
Cotter, K.L., 1999, Microfossils from Neoproterozoic Supersequence 1 of the Officer Basin, Western Australia: Alcheringa, v. 23, p. 63-86.

De Leeuw, J.W., Vesteegh, J.M., and van Bergen, P.F., 2006, Biomacromolecules of algae and plants and their fossil analogues: Plant Ecology, v. 182, p. 209-233.

de Vries, S.T., Pryer, L.L., and Fry, N., 2008, Evolution of Neoarchaean and Proterozoic basins of Australia: Precambrian Research, v. 166, p. $39-53$.

Dong, L., Xiao, S., Shen, B., and Zhou, C., 2008, Silicified Horodyskia and Palaeopascichnus from upper Ediacaran cherts in South China: tentative phylogenetic interpretation and implications for evolutionary stasis: Journal of the Geological Society, v. 165, p. 367-378.

Douzery, E.J.P., Snell, E.A., Bapteste, E., Delsuc, F., and Philippe, H., 2004 The timing of eukaryotic evolution: Does a relaxed molecular clock reconcile proteins and fossils?: Proceedings of the National Academy of Sciences, v. 101, p. 15386-15391.

Downie, C., and Sarjeant, W.A.S., 1963, On the interpretation and status of some hystrichosphere genera: Palaeontology, v. 6, p. 83-96.

Dutkiewicz, A., Volk, H., Ridley, J., and George, S., 2003, Biomarkers, brines and oil in the Mesoproterozoic, Roper Superbasin, Australia: Geology, v. 31, p. $981-984$.

Eisenack, A., 1958, Tasmanites Newton 1875 und Leiosphaeridia n.g. als Gattungen der Hystrichosphaeridea: Palaeontographica Abteilug A, v. 110, p. $1-19$.

Eisenack, A., 1965, Mikrofossilien aus dem Silur Gotlands. Hystrichosphären, Problematika: Neues Jahrburch für Geologie und Paläontologie Abhandlungen, v. 122 , p. $257-274$

Eme, L., Sharpe, S.C., Brown, M.W., and Roger, A.J., 2014, On the age of eukaryotes: Evaluating evidence from fossils and molecular clocks: Cold Spring Harbor Perspectives in Biology, v. 6, doi: 10.1101/cshperspect. a016139.

Fedonkin, M.A., and Yochelson, E.L., 2002, Middle Proterozoic (1.5 Ga) Horodyskia moniliformis Yochelson and Fedonkin, the oldest known tissue-grade colonial eukaryote: Smithsonian Contributions to Paleobiology, v. 94, p. 1-29.

Floudas, I., et al., 2012, The Paleozoic origin of enzymatic lignin decomposition reconstructed from 31 fungal genomes: Science, v. 336, p. 1715-1719, doi: $10.1126 /$ science.1221748.

Foissner, W., Mueller, H., and Agatha, S., 2007, A comparative fine structural and phylogenetic analysis of resting cysts in oligotrich and hypotrich Spirotrichea (Ciliophora): European Journal of Protistology, v. 43, p. 295-314.

Golovenok, M.K., and Belova, M.Y., 1986, The Riphean microflora in the cherts from the Malgin Formation in the Yudoma-Maya basin: Paleontological Journal, v. 2, p. 85-90.

Golubic, S., Sergeev, V.N., and Knoll, A.H., 1995, Mesoproterozoic Archaeoellipsoides: akinetes of heterocystous cyanobacteria: Lethaia, v. 28, p. $285-298$.

Graham, L.E., and Wilcox, L.W., 2000, Algae: Upper Saddle River NJ, Prentice Hall, $640 \mathrm{p}$.

Grey, K., and Williams, I.R., 1990, Problematic bedding-plane markings from the Middle Proterozoic Manganese Subgroup, Bangemall Basin, Western Australia: Precambrian Research, v. 46, p. 307-327.

Grotzinger, J.P., and Knoll, A.H., 1999, Proterozoic stromatolites: evolutionary mileposts or environmental dipsticks?: Annual Review of Earth and Planetary Science, v. 27, p. 313-358

Guilbaud, R., Poulton, S.W., Butterfield, N.J., Zhu, M., and Shields-Zhou, G.A., 2015, Global transition to ferruginous conditions in the early Neoproterozoic oceans: Nature Geosciences, v. 8, p. 466-470.

Heckman, D.S., Geiser, D.M., Eidell, B.R., Stauffer, R.L., Kardos, N.L., and Hedges, S.B., 2001, Molecular Evidence for the Early Colonization of Land by Fungi and Plants: Science, v. 293, p. 1129-1133.

Hedges, B.S., Blair, J.E., Venturi, M.L., and Shoe, J.L., 2004 A molecular timescale of eukaryote evolution and the rise of complex multicellular life: BMC Evolutionary Biology, v. 4, article 2, doi: $10.1186 / 1471-2148-4-2$.

Hermann, T.N., 1974, Finds of massive accumulation of trichomes in the Riphean, in Timofeev, B.V., ed., Microfitofossilii Proterozoia I Rannego Paleozoia SSSR: Leningrad, Nauka, p. 6-10.

Hermann, T.N., 1990, Organic world one billion years ago: Leningrad, Nauka, 50 p. [in Russian with English summary]

Hermann, T.N., and Podkovyrov, V.N., 2012, Fungal Remains from the Late Riphean: Paleontological Journal, v. 40, p. 207-214.

Hofmann, H.J., 1999, Global distribution of the Proterozoic sphaeromorph acritarch Valeria lophostriata (Jankauskas): Acta Micropaleontologica Sinica, v. 16, p. 215-224.

Hofmann, H.J., and Jackson, G.D., 1994, Shale-facies microfossils from the Proterozoic Bylot Supergroup, Baffin Island, Canada: Paleontological Society Memoir, v. 37, p. 1-39. 
Horodyski, R.J., 1980, Middle Proterozoic shale-facies microbiota from the Lower Belt Supergroup, Little Belt Mountains, Montana: Journal of Paleontology, v. 54, p. 649-663.

Horodyski, R.J., 1993, Paleontology of Proterozoic shales and mudstones: examples from the Belt Supergroup, Chuar Group and Pahrump Group, western USA: Precambrian Research, v. 61, p. 247-278.

Horodyski, R.J., and Donaldson, J.A., 1980, Microfossils from the Middle Proterozoic Dismal Lakes Groups, Arctic Canada: Precambrian Research, v. 11, p. $125-159$

Horodyski, R.J., and Donaldson, J.A., 1983, Distribution and Significance of Microfossils in Cherts of the Middle Proterozoic Dismal Lakes Group, District of Mackenzie, Northwest Territories, Canada: Journal of Paleontology, v. 57, p. 271-283.

Hu, Y., and Fu, J., 1982, Micropalaeoflora from the Gaoshanhe Formation of the Upper Precambrian in Luonan of Shaanxi Province and its stratigraphic significance: Bulletin Xi'an Institute Geology and Mineral Resources, Chinese Academy of Geological Sciences, v. 4, p. 102-113.

Hu, G., Zhao, T., and Zhou, Y., 2014, Depositional age, provenance and tectonic setting of the Proterozoic Ruyang Group, southern margin of the North China Craton: Precambrian Research, v. 246, p. 296-318.

Ishida, K., and Hara, Y., 1994, Taxonomic studies on the Chlorarachniophyta Chlorarachnion globosum sp. nov.: Phycologia, v. 33, p. 351-358.

Jackson, M.J., and Raiswell, R., 1991, Sedimentology and carbon-sulfur geochemistry of the Velkerri Formation, a mid-Proterozoic potential oil source in northern Australia: Precambrian Research, v. 54, p. 81-108.

Jackson, M.J., Sweet, I.P., Page, R.W., and Bradshaw, B.E., 1999, The South Nicholson and Roper Groups: evidence for the early Mesoproterozoic Roper Superbasin, in Bradshaw, B.E., and Scott, D.L., eds., Integrated Basin Analysis of the Isa Superbasin using Seismic, Well-log, and Geopotential Data: An Evaluation of the Economic Potential of the Northern Lawn Hill Platform: Canberra, Australia, Australian Geological Survey Organisation Record 1999/19. [unpaginated]

Jankauskas, T.V., 1979a, Nizhnerifeiskie mikrobioty Iuzhnogo Urala (Lower Riphean microbiotas of the southern Urals): Akademii Nauk SSSR, Doklady (Proceedings of the USSR Academy of Sciences), v. 247, p. 1465-1467. [In Russian]

Jankauskas, T.V., 1979b, Srednerifeyski microbiota Yuzhnogo Urala i Bashkirskogo Priural'ya (Middle Riphean microbiota of the southern Urals and the Ural region in Bashkiria): Akademii Nauk SSSR, Doklady (proceedings of the USSR Academy of Sciences), v. 248, p. 190-193. [in Russian]

Jankauskas, T.V., 1982, Mikrofossilii rifeya Yuzhnogo Urala [Microfossils of the Riphean of the South Urals], in Keller, B.M., ed., Stratotype of the Riphean: Paleontology and Paleomagnetics: Moscow, Nauka, p. 84-120.

Jankauskas, T.V., Mikhailova, N., and Hermann, T.N., 1989, Mikrofossilii dokembriya SSSR (Precambrian microfossils of the USSR): Leningrad, Trudy Instituta Geologii i Geochronologii Dokembria SSSR Akademii Nauk. Nauka, 188 p. [In Russian]

Javaux, E.J., 2006, The early eukaryote fossil record, in Jékely, G., ed., Evolution of the Eukaryotic Endomembrane System and Cytoskeleton: Austin, Texas, Landes Biosciences Publishers, p. 1-19.

Javaux, E.J., 2011, Evolution of early eukaryotes in Precambrian oceans, in Gargaud, M., Lopez-Garcia, P., and Martin, H., eds., Origins and Evolution of Life: an astrobiology perspective: Cambridge, UK, Cambridge University Press, p. 414-449.

Javaux, E.J., and Marshall, C.P., 2006, A new approach in deciphering early protist paleobiology and evolution: combined microscopy and microchemistry of single Proterozoic acritarchs: Review of Palaeobotany and Palynology, v. 139 , p. $1-15$.

Javaux, E.J., Knoll, A.H., and Walter, M.R., 2001, Ecological and morphological complexity in early eukaryotic ecosystems: Nature, v. 412, p. 66-69.

Javaux, E.J., Knoll, A.H., and Walter, M.R., 2003, Recognizing and interpreting the fossils of early eukaryotes: Origins of Life and Evolution of the Biosphere, v. 33, p. 75-94.

Javaux, E.J., Knoll, A.H., and Walter, M.R., 2004, TEM evidence for eukaryotic diversity in mid-Proterozoic oceans: Geobiology, v. 2, p. 121-132.

Javaux, E.J., Marshall, C.P., and Bekker, A., 2010, Organic-walled microfossils in 3.2-billion-year-old shallow-marine siliciclastic deposits: Nature, v. 463, p. $934-938$.

Jékely, G., 2006, Evolution of the Eukaryotic Endomembrane System and Cytoskeleton: Advances in Experimental Medicine and Biology, v. 607: Austin, Texas, Landes Biosciences Publishers, 145 p.

Johnston, D.T., Farquhar, J., Summons, R.E., Shen, Y., Kaufman, A.J., Masterson, A.L., and Canfield, D.E., 2008, Sulfur isotope biogeochemistry of the Proterozoic McArthur Basin: Geochimica et Cosmochimica Acta, v. 72, p. 4278-4290.

Johnston, D.T, Wolfe-Simon, F., Pearson, A., and Knoll, A.H., 2009, Anoxygenic photosynthesis modulated Proterozoic oxygen and sustained Earth's middle age: Proceedings of the National Academy of Sciences, USA, v. 106, p. $16925-16929$.
Johnston, D.T, Poulton, S., Dehler, C., Porter, S., Husson, J., and Canfield, D.E., 2010, An emerging picture of Neoproterozoic ocean chemistry: Insights from the Chuar Group, Grand Canyon, USA: Earth and Planetary Science Letters, v. 290, p. 64-73.

Johnston, D.T., Goldberg, T., Poulton, S.W., Sergeev, V.N., Podkovyrov, V., Vorob'eva, N.G., Bekker, A., and Knoll, A.H., 2012, Late Ediacaran redox stability and metazoan diversification: Earth and Planetary Science Letters, v. $335-336$, p. $25-35$.

Kaufman, A.J., and Xiao, S., 2003, High $\mathrm{CO}_{2}$ levels in the Proterozoic atmosphere estimated from analyses of individual microfossils: Nature, v. 425 , p. $279-282$.

Kendall, B., Creaser, R.A., Gordon, G.W., and Anbar, A.D., 2009, Re-Os and Mo isotope systematics of black shales from the Middle Proterozoic Velkerri and Wollogorang Formations, McArthur Basin, northern Australia: Geochimica et Cosmochimica Acta, v. 73, p. 2534-2558.

Kenrick, P., and Vinther, J., 2006, Chaetocladus gracilis n. sp., a non-calcified Dasycladales from the Upper Silurian of Skåne, Sweden: Review of Palaeobotany and Palynology, v. 142, p. 153-160.

Knoll, A.H., 2014, Paleobiological perspective on early eukaryotic evolution: Cold Spring Harbor Perspectives in Biology, doi: 10.1101/cshperspect. a016121.

Knoll, A.H., and Golubic, S., 1992, Living and Proterozoic cyanobacteria, in Schidlowski M., Golubic, S., and Kimberley, M.M., eds., Early Organic Evolution: Implications for Mineral and Energy Resources: Berlin, Springer-Verlag, p. 450-462.

Knoll, A.H., and Lahr, D.J.G., 2016, Fossils, feeding, and the evolution of complex multicellularity, in Niklas, K.J., Newman, S., and Bonner, J.T., eds., Multicellularity, Origins and Evolution, The Vienna Series in Theoretical Biology: Boston, Massachusetts Institute of Technology, p. 1-16.

Knoll, A.H., and Swett, K., 1985, Micropalaeontology of the Late Proterozoic Veteranen Group, Spitsbergen: Palaeontology, v. 28, p. 451-473.

Knoll, A.H., Swett, K., and Mark, J., 1991, Paleobiology of a Neoproterozoic tidal flat/lagoonal complex: the Draken Conglomerate Formation, Spitsbergen: Journal of Paleontology, v. 65, p. 531-570.

Knoll, A.H., Javaux, E.J., Hewitt, D., and Cohen, P., 2006, Eukaryotic organisms in Proterozoic oceans: Philosophical Transactions of the Royal Society, London, v. 361B, p. 1023-1038.

Knoll, A.H., Wörndle, S., and Kah, L., 2013, Covariance of microfossil assemblages and microbialite textures across a late Mesoproterozoic carbonate platform: Palaios, v. 28, p. 453-470.

Kodner, R., Knoll, A.H., and Summons, R.E., 2009, Phylogenetic investigation of the aliphatic, non-hydrolyzable biopolymer algaenan, with a focus on the green algae: Organic Geochemistry, v. 40, p. 854-862.

Kralik, M., 1982, Rb-Sr age determinations on Precambrian carbonate rocks of the Carpentarian McArthur Basin, Northern Territories, Australia: Precambrian Research, v. 18, p. 157-170.

Lamb, D.M., Awramik, S.M., Chapman, D.J., and Zhu, S., 2009, Evidence for eukaryotic diversification in the similar to 1800 million-year-old Changzhougou Formation, North China: Precambrian Research, v. 173, p. 93-104.

Lan, Z., Li, X., Chen, Z.Q., Li, Q., Hofmann, A., Zhang, Y., Liu, Y., Tang, G., Ling, X., and Li., J., 2014, Diagenetic xenotime age constraints on the Sanjiaotang Formation,Luoyu Group, southern margin of the North China Craton: Implications for regional stratigraphic correlation and early evolution of eukaryotes: Precambrian Research, v. 251, p. 21-32.

Lepot, K., Compère, P., Gérard, E., Namsaraev, Z., Verleyen, E., Tavernier, I., Hodgson, D.A., Vyverman, W., Gilbert, B., Wilmotte, A., and Javaux, E.J., 2014, Organic and mineral imprints in fossil photosynthetic mats of an East Antarctic lake: Geobiology, v. 12, p. 424-450.

LoDuca, S.T., Kluessendorf, J., and Mikulic, D.G., 2003, A new noncalcified dasycladalean alga from the Silurian of Wisconsin: Journal of Paleontology, v. 77 , p. $956-962$.

Lopez-Garcia, P., and Moreira, D., 2015, Open Questions on the Origin of Eukaryotes: Trends in Ecology and Evolution, v. 30, p. 697-708.

Lücking, R., Huhndorf, S., Pfister, D.H., Plata, E.R., and Lumbsch, H.T., 2009, Fungi evolved right on track: Mycologia, v. 101, p. 810-822.

Luo, Q.-L., 1991, New data on the microplants from Changlongshan Formation of Upper Precambrian in western Yanshan Range: Tianjin Instute of Geology and Mineral Resources, v. 25, p. 107-118.

Lydon, J.W., 2007, Geology and metallogeny of the Belt-Purcell Basin, in Goodfellow, W.D., ed., Mineral Deposits of Canada: A Synthesis of Major Deposit-Types, District Metallogeny, the Evolution of Geological Provinces, and Exploration Methods: Geological Association of Canada, Mineral Deposits Division, Special Publication No. 5, p. 581-607.

Maithy, P.K., 1975, Microorganisms from the Bushimay System (Late Precambrian) of Kanshi, Zaire: The Paleobotanist, v. 22, p. 133-149.

Marshall, C.P., Javaux, E.J., Knoll, A.H., and Walter, M.R., 2005, Combined micro-Fourier transform infrared (FTIR) spectroscopy and micro-Raman spectroscopy of Proterozoic acritarchs: a new approach to palaeobiology: Precambrian Research, v. 138, p. 208-224. 
Melida, H., Sandoval-Sierra, J.V., Dieguez-Uribeondo, J., and Bulone, V., 2013, Analyses of extracellular carbohydrates in oomycetes unveil the existence of three different cell wall types: Eukaryotic Cell, v. 12, p. 194-203.

Mitra, A., et al., 2016, Defining Planktonic Protist Functional Groups on Mechanisms for Energy and Nutrient Acquisition: Incorporation of Diverse Mixotrophic Strategies: Protist, v. 167, p. 106-120.

Moczydłowska, M., Landing, E., Zang, W., and Palacios, T., 2011, Proterozoic phytoplankton and timing of Chlorophyte algae origins: Palaeontology, v. 54 , p. $721-733$.

Muir, M.D., 1976, Proterozoic microfossils from the Amelia Dolomite, McArthur Basin, Northern Territory: Alcheringa, v. 1, p. 143-158.

Muir, M.D., 1979, A sabkha model for the deposition of part of the Proterozoic McArthur Group of the Northern Territory, and its implications for mineralization: BMR Journal of Australian Geology and Geophysics, v. 4 , p. $149-162$.

Müller, M., Mentel, M., van Hellemond, J.J., Henze, K., Woehle, K., Gould, S. B., Yu, R.-Y., van der Giezen, R.M., Tielens, A.G.M., and Martin, W.F., 2012, Biochemistry and evolution of anaerobic energy metabolism in eukaryotes: Microbiology and Molecular Biology Reviews, v. 76, p. 444-495.

Nagovitsin, K., 2009, Tappania-bearing association of the Siberian platform: Biodiversity, stratigraphic position and geochronological constraints: Precambrian Research, v. 173, p. 137-145.

Nagovitsin, K.E., Stanevich, A.M., and Kornilova, T.A., 2010, Stratigraphic setting and age of the complex Tappania-bearing Proterozoic fossil biota of Siberia: Russian Geology and Geophysics, v. 51, p. 1192-1198.

Nagy, R.M., Porter, S.M., Dehler, C.M., and Shen, Y., 2009, Biotic turnover driven by eutrophication before the Sturtian low-latitude glaciation: Nature Geoscience, v. 2, p. 415-418.

Naumova, S.N., 1949, Spory nizhnego kembriya [spores from the Lower Cambrian]: Izvestiya Akademiy Nauk, v. 4, p. 49-56.

Naumova, S.N., 1960, Spore-pollen assemblages in the Riphean and Lower Cambrian deposits of the USSR: Proceedings of the $21^{\text {st }}$ International Geological Congress, Reports of Soviet Scientists, v. 8, p. 109-117. [in Russian]

Oehler, D.Z., 1978, Microflora of the middle Proterozoic Balbirini Dolomite (McArthur Group) of Australia: Alcheringa, v. 2, p. 269-309.

Parfrey, L., Lahr, D., Knoll, A.H., and Katz, L.A., 2011, Estimating the timing of early eukaryotic diversification with multigene molecular clocks: Proceedings of the National Academy of Sciences, USA, v. 108 p. $13624-13629$

Peat, C.J., Muir, M.D., Plumb, K.A., McKirdy, D.M., and Norwick, M.S., 1978 Proterozoic microfossils from the Roper Group, Northern Territory, Australia: BMR Journal of Australian Geology and Geophysics, v. 3, p. 1-17.

Peng, Y., Bao, H., and Yuan, X., 2009, New morphological observations for Paleoproterozoic acritarchs from the Chuanlinggou Formation, North China: Precambrian Research, v. 168, p. 223-232.

Peterson, K.J., and Butterfield, N.J., 2005, Origin of the Eumetazoa: Testing ecological predictions of molecular clocks against the Proterozoic fossil record: Proceedings of the National Academy of Sciences, USA v. 102 , p. 9547-9552.

Planavsky, N.J., McGoldrick, P., Scott, C.T., Li, C., Reinhard, C.T., Kelly, A.E., Chu, X., Bekker, A., Love, G.D., and Lyons, T.W., 2011, Widespread ironrich conditions in the mid-Proterozoic ocean: Nature, v. 477, p. 448-452.

Porter, S., 2006, The Proterozoic fossil record of heterotrophic eukaryotes, in Xiao, S., and Kaufman, A.J., eds. Neoproterozoic Geobiology and Paleobiology: Dordrecht, The Netherlands, Springer, p. 1-21.

Porter, S., and Riedmann, L.A., in press, Systematics of organic-walled microfossils from the $780-740$ Ma Chuar Group, Grand Canyon, Arizona: Journal of Paleontology.

Porter, S., Meisterfeld, R., and Knoll, A., 2003, Vase-shaped microfossils from the Neoproterozoic Chuar Group, Grand Canyon: a classification guided by modern testate amoebae: Journal of Paleontology, v. 77, p. 409-429, doi http://dx.doi.org/10.1017/S0022336000044140.

Prasad, B., and Asher, R., 2001, Acritarch biostratigraphy and lithostratigraphic classification of Proterozoic and Lower Paleozoic sediments (Preunconformity sequence) of Ganga Basin, India: Paleontographica Indica, v. 5,151 p.

Prasad, B., Uniyal, S.N., and Asher, R., 2005, Organic-walled microfossils from the Proterozoic Vindhyan Supergroup of Son Valley, Madhya Pradesh, India: Palaeobotanist, v. 54, p. 13-60.

Ray, J.S., Martin, M.W., Veizer, J., and Bowring, S.A., 2002, U-Pb zircon dating and $\mathrm{Sr}$ isotope systematics of the Vindhyan Supergroup, India: Geology, v. 30, p. 131-134.

Reinhard, C.T., Planavsky, N.J., Robbins, L.J., Partin, C.A., Gill, B.C., Lalonde, S.V., Bekker, A., Konhauser, K.O., and Lyons, T.W., 2013, Proterozoic ocean redox and biogeochemical stasis: Proceedings of the National Academy of Sciences, USA, v. 110, p. 5357-5362.
Richards, T.A., and Talbot, N.J., 2013, Horizontal gene transfer in osmotrophs: playing with public goods: Nature Reviews Microbiology, v. 11, p. $720-727$.

Riedman, L.A., and Porter, S.M., in press, High morphological diversity of organic-walled microfossils from the Neoproterozoic Alinya Formation, Officer Basin, Australia: Journal of Paleontology.

Rippka, R., Deruelles, J., Waterbury, J.B., Herdman, M., and Stanier, R.Y., 1979, Generic assignments, strain histories and properties of pure cultures of cyanobacteria: Journal of General Microbiology, v. 111, p. 1-61.

Saga, Y., and Yanagisawa, K., 1982, Macrocyst development in Dictvostelium discoideum. 1. Induction of synchronous development by giant cells and biochemical analysis: Journal of Cell Science, v. 55, p. 341-352.

Samuelsson, J., 1997, Biostratigraphy and paleobiology of early Neoproterozoic strata of the Kola Peninsula, northwest Russia: Norsk Geologisk Tidsskrift, v. 77 , p. 16-192.

Samuelsson, J., and Butterfield, N., 2001, Neoproterozoic fossils from the Franklin Mountains, northwestern Canada: stratigraphic and palaeobiological implications: Precambrian Research, v. 107, p. 235-251.

Samuelsson, J., Dawes, P.R., and Vidal, G., 1999, Organic-walled microfossils from the Proterozoic Thule Supergroup, Northwest Greenland: Precambrian Research, v. 96, p. 1-23.

Schepeleva, E.D., 1960, Nakhodki sinezelenykh vodoroslej v nizhnekembrijskikh otlozheniyakh Leningradskoj oblasti [Finds of blue-green algae in Lower Cambrian deposits of the Leningrad region]. in., Problemy Neftyanoj Geologii i Voprosy Metodiki Laboratornykh Issledovanij: Moscow, Nauka, p. $170-172$.

Schiffbauer, J.D., and Xiao, S., 2009, Novel application of focused ion beam electron microscopy (FIB-EM) in preparation and analysis of microfossil ultrastructures: a new view of complexity in early eukaryotic organisms: Palaios, v. 24, p. 616-626.

Scholz, M.J., Weiss, T.L., Jinkerson, R.E., Jing, J., Roth, R., Goodenough, U., Posewitz, M.C., and Gerkene, H.G., 2014, Ultrastructure and composition of the Nannochloropsis gaditana cell wall: Eukaryotic Cell, v. 13, p. $1450-1464$.

Schopf, W., 1968, Microflora of the Bitter Springs Formation, late Precambrian, central Australia: Journal of Paleontology, v. 42, p. 651-688.

Schopf, J.W., 1992, Atlas of representative Proterozoic microfossils, in Schopf, J.W., and Klein, C., eds., The Proterozoic Biosphere: Cambridge, Cambridge University Press, p. 1057-1117.

Schopf, J.W., and Blacic, J., 1971, Microorganisms from the Bitter Springs Formation (Late Precambrian) of the North-Central Amadeus Basin, Australia: Journal of Paleontology, v. 45, p. 925-960.

Sergeev, V.N., 1992, Silicified Microfossils of the Precambrian and Cambrian in the Urals and central Asia: Moscow, Nauka, 139 p. [in Russian]

Sergeev, V.N., 2006, Precambrian Microfossils in Cherts : Their Paleobiology, Classification, and Biostratigraphic Usefulness: Moscow, Geos, 280 p. [in Russian]

Sergeev, V.N., and Lee, S.-J., 2001, Microfossils from Cherts of the Middle Riphean Svetlyi Formation, the Uchur-Maya Region of Siberia, and Their Stratigraphic Significance: Stratigraphic Geological Correlation, v. 9, p. 3-12.

Sergeev, V.N., and Lee, S.-J., 2006, Real Eukaryotes and Precipitates First Found in the Middle Riphean Stratotype, Southern Urals: Stratigraphy and Geological Correlation, v. 14, p. 1-18.

Sergeev, V.N., Knoll, A.H., and Grotzinger, J.P., 1995, Paleobiology of the Mesoproterozoic Billiakh Group, Anabar Uplift, Northeastern Siberia: Paleontological Society Memoir, v. 39, 37 p.

Sergeev, V.N., Semikhatov, M.A., Fedonkin, M.A., and Vorob'eva, N.G., 2010 Principal stages in evolution of Precambrian organic world: 2. The late Proterozoic: Stratigraphy and Geological Correlation, v. 18, p. 561-592.

Sergeev, V.N, Knoll, A.H., Vorob'eva, N., and Sergeeva, N., 2016, Microfossils from the lower Mesoproterozoic Kaltasy Formation, East European Platform: Precambrian Research, v. 278, p. 87-107, doi: 10.1016/ j.precamres.2016.03.015.

Shen, Y., Knoll, A.H., and Walter, M.R., 2003, Evidence for low sulphate and deep water anoxia in a mid-Proterozoic marine basin: Nature, v. 423, p. 632-635.

Sperling, E.A., Rooney, A.D., Hays, L., Sergeev, V.N., Vorob'eva, N.G., Sergeeva, N.D., Selby, D., Johnston, D.T., and Knoll, A.H., 2014, Redox heterogeneity of subsurface waters in the Mesoproterozoic ocean: Geobiology, v. 12, p. 373-386.

Stanevich, A.M., Maksimova, E.N., Kornilova, T.A., Gladkochub, D.P., Mazukabzov, A.M., and Donskaya, T.V., 2009, Microfossils from the Arymas and Debengde Formations, the Riphean of the Olenek Uplift: Age and presumable nature: Stratigraphy and Geological Correlation, v. 17, p. $20-35$. 
Strother, P.K., Knoll, A.H., and Barghoorn., E.S., 1983, Microorganisms from the late Precambrian Narssârssuk Formation, north-western Greenland: Palaeontology, v. 26, p. 1-32.

Strother, P., Battison, L., Brasier, M.D., and Wellman, C.H., 2011, Earth's earliest non-marine eukaryotes: Nature, v. 473, p. 505-509.

Stüeken, E.E., 2013, A test of the nitrogen-limitation hypothesis for retarded eukaryote radiation: Nitrogen isotopes across a Mesoproterozoic basinal profile: Geochimica et Cosmochimica Acta, v. 20, p. 121-139.

Su, W., Li, H., Xu, L., Jia, S., Geng, J., Zhou, H., Wang, Z., and Pu, H.-Y., 2012, Luoyu and Ruyang Group at the south margin of the North China Craton (NCC) should belong in the Mesoproterozoic Changchengian System: direct constraints from the LA-MC-ICPMS U-Pb age of the tuffite in the Luoyukou Formation, Ruzhou, Henan, China: Geological Survey and Research, v. 35, p. 96-108.

Sugitani, K., Mimura, K., Takeuchi, M., Lepot, K., Ito, S., and Javaux, E.J., 2015, Early evolution of large micro-organisms with cytological complexity revealed by microanalyses of $3.4 \mathrm{Ga}$ organic-walled microfossils: Geobiology, v. 13, p. 522-545.

Talyzina, N., and Moczydłowska, M., 2000, Morphological and ultrastructural studies of some acritarchs from the Lower Cambrian Lukati Formation, Estonia: Review of Palaeobotany and Palynology, v. 112, p. 1-21.

Tang, Q., Pang, K., Yuan, X., Wan, B., and Xiao, S., 2015, Organic-walled microfossils from the Tonian Gouhou Formation, Huaibei region, North China Craton, and their biostratigraphic implications: Precambrian Research, v. 266, p. 296-318.

Timofeev, B.V., 1959, Dreveneyshaya flora Pribaltiki i ee stratigraficheskoe znachenie (Oldest flora of the Baltic area and its stratigraphic significance): Trudy Vsesoyuznogo Neftyanogo Nauchno-Issle-dovatel'skogo Geologorazvedochnogo Instituta (VNIGRI), v. 129, 320 p. [in Russian]

Timofeev, B.V., 1966, Mikropaleofitologicheskoe isslodovanie drevnikh svit (Microphytological investigations of ancient formations): Akademiya Nauk SSSR, Nauka, Moscow, 147 p. [in Russian]

Timofeev, B.V., Hermann, T.N., and Mikhailova, N.S., 1976, Mikrofitofossilii Dokembriia, Kembriia i Ordovika (Plant Microfossils of the Precambrian, Cambrian, and Ordovician): Leningrad, Scientific Institute of Precambrian Geology and Geochronology, 106 p. [in Russian]

Tomitani, A., Knoll, A.H., Cavanaugh, C.M., and Ohno, T., 2006, The evolutionary diversification of cyanobacteria: Molecular-phylogenetic and paleontological perspectives: Proceedings of the National Academy of Sciences, v. 103 , p. 5442-5447.

Turner, R.E., 1984, Acritarchs from the type area of the Ordovicain Caradoc Series, Shropshire, England: Palaeontographica, Abteiling B, v. 190 , p. $87-157$.

Verni, F., and Rosati, G., 2011, Resting cysts: a survival strategy in Protozoa Ciliophora: Italian Journal of Zoology, v. 78, p. 134-145.

Vidal, G., and Ford, T.D., 1985, Microbiotas from the late Proterozoic Chuar Group (northern Arizona) and Uinta Mountain Group (Utah) and their chronostratigraphic implications: Precambrian Research, v. 28, p. 349-389.

Vidal, G., and Siedlecka, A., 1983, Planktonic, acid-resistant microfossils from the Upper Proterozoic strata of Barents Sea region of Varanger Peninsula, East Finnmark, Northen Norway: Norges Geologiske undersøkelse Bulletin, v. 382, p. 45-79.
Vorob'eva, N.G., Sergeev, V.N., and Yu, P., 2015, Kotuikan Formation assemblage: a diverse organic-walled microbiota in the Mesoproterozoic Anabar succession, northern Siberia: Precambrian Research, v. 256, p. 201-222.

Waterbury, J.M., and Stanier, R.Y., 1978, Patterns of growth and development in pleurocapsalean cyanobacteria: Microbiological Reviews, v. 42, p. $2-44$.

Walter, M.R., Krylov, I.N., and Muir, M.D., 1988, Stromatolites from Middle and Late Proterozoic sequences in the McArthur and Georgina Basins and the Mount Isa Province, Australia: Alcheringa, v. 12, p. 79-106.

Walter, M.R., Du, R.L., and Horodyski, R.J., 1990, Coiled carbonaceous megafossils from the Middle Proterozoic of Jixian (Tianjin) and Montana: American Journal of Science, v. 290A, p. 133-148.

Xiao, S.H., Knoll, A.H., Kaufman, A.J., Yin, L.M., and Zhang, Y., 1997, Neoproterozoic fossils in Mesoproterozoic rocks? Chemostratigraphic resolution of a biostratigraphic conundrum from the North China Platform: Precambrian Research, v. 84, p. 197-220.

Xiao, S.H., Yuan, X.L., Steiner, M., and Knoll, A.H., 2002, Macroscopic carbonaceous compressions in a terminal Proterozoic shale: A systematic reassessment of the Miaohe biota, south China: Journal of Paleontology, v. 76, p. 347-376.

Xing, Y., and Liu, K., 1973, On Sinian microflora in Yenliao region of China and its geographic significance: Acta Geologica Sinica, v. 1, p. 1-64.

Yang, E.C., Boo, S.M., Battacharya, D., Saunders, G.W., Knoll, A.H., Fredericq, S., Graf, L., and Yoon, H.S., 2016, Divergence times estimates and the evolution of major lineages in the florideophyte red algae: Scientific Reports, 2016 Feb 19;6:21361, doi: 10.1038/srep21361.

Yin, L.M., 1997, Acanthomorphic acritarchs from Meso-Neoproterozoic shales of the Ruyang Group, Shanxi, China: Review of Palaeobotany and Palynology, v. 98, p. 15-25.

Yin, L., and Yuan, X., 2007, Radiation of Meso-Neoproterozoic and Early Cambrian protists inferred from the microfossil record of China: Palaeogeography, Palaeoclimatology, Palaeoecology, v. 254, p. 350-361.

Yin, L.M., Yuan, X.L., Meng, F.W., and Hu, J., 2005, Protists of the Upper Mesoproterozoic Ruyang Group in Shanxi Province, China: Precambrian Research, v. 141, p. 49-66.

Yoon, H.S., Hackett, J.D., Ciniglia, C., Pinto, G., and Bhattacharya, D., 2004, A molecular timeline for the origin of photosynthetic eukaryotes: Molecular and Biological Evolution, v. 21, p. 809-818.

Yuan, X., Chen, Z., Xiao, S., Zhou, C.M., and Hua, H., 2011, An early Ediacaran assemblage of macroscopic and morphologically differentiated eukaryotes: Nature, v. 470, p. 390-393.

Xiao, S., Knoll, A.H., Kaufman, A.J., Yin, L., and Zhang, Y., 1997, Neoproterozoic fossils in Mesoproterozoic rocks? Chemostratigraphic resolution of a biostratigraphic conundrum from the North China Platform: Precambrian Research, v. 84, p. 197-220.

Zhang, Y., 1981, Proterozoic stromatolite microfloras of the Gaoyuzhuang Formation (Early Sinian: Riphean), Hebei, China: Journal of Paleontology, v. 55 , p. $485-506$.

Accepted 11 May 2016 